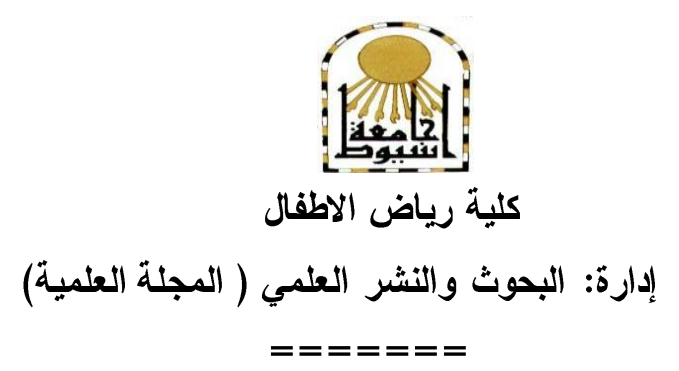

\title{
أثر الثربية المدنية فى تنمية الانتماء والمواطنة والمسئولية الاجتهاعية لدى طفل الروضة
}

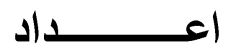 \\ د/هنــال أنـــور ســـيد \\ مدرس بقسم العلوم التريوية \\ كلية رياض الأطفال -جامعة أسيوط الكرية \\ أ. د/هاجدة هاث-سم بخيت \\ أستاذ الفئات الخاصة وعميد \\ كلية رياض الأطفال - جامعة أسيوط
}

|أ جمالات غيط عليوه هصطفى

بإدارة أبنوب التعليمية أطفال

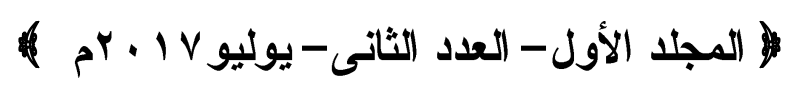


أ.د/ ماجدة هاشـم بخيت

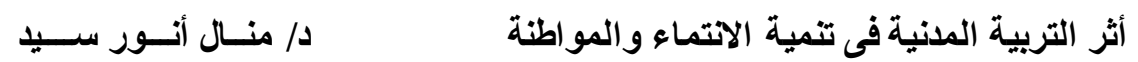

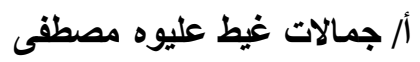

مستخلص الار اسة

عنوان الاراسة : أثز التربية المدنية فى تتمية الانتماء والمواطنة والمسئولية الاجتماعية

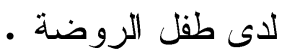
جهة الار اسة : كلية التربية - جامعة أسيوط .

هدف الار اسة : تتمية بعض مفاهيم الانتماء و المواطنة وتحمل المسئولية الاجتماعية لدى لدى لئية

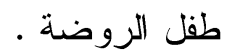

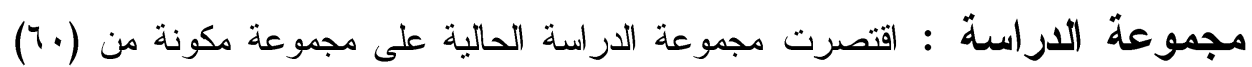

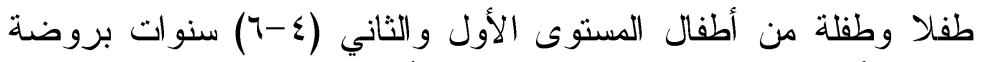

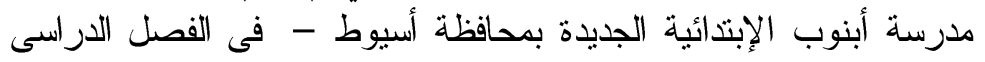

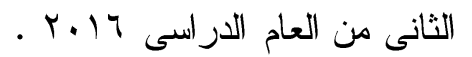

منهج اللاراسة :استخدمت الدراسة الحالية المنهج شبه التجريبي القائم على تصميم مجمو عتين إحداهما تجريبية و الآخرى ضابطة. أدوات الار اسة : لتحقيق هدف الداسة تم إعداد الأدوات التالية :

1- استطلاع رأى للمعلمات حول دور التربية المدنية فى تتمية الإنتماء و المواطنة

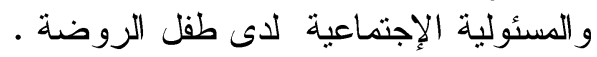
r- مقياس مفاهيم الإنتماء المصور لطفل الروضة . r- مقياس مفاهيم المواطنة المصور لطفل الروضة . ـ - مقياس تحمل المسئولية الإجتماعية المصور لطفل الروضة.(إعداد حسنيه عنيمى $(r \cdot) \cdot 6$

0- برنامج تدريبي للتربية المدنية لطفل الروضة . نتائج الار اسة : توصلت الدراسة إلى : نامئ

وجود فروق ذات دالة إحصائية للتربية المدنية في تتميه بعض مفاهيم الإنتماء و المو اطنة وتحمل المسئولية الإجتماعية لاى أطفال الروضة بعد تطبيق البرنامج وذللك لصالح المجموعة

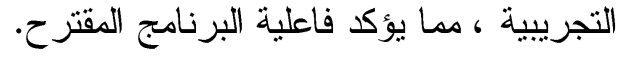

الكثمات المقتاحية : التربية المدنية- الإنتماء - المواطنة - المسئولية الإجتماعية طفل الروضة 


\section{المجلة العلمية لكلية رياض الاطفال - جامعة اسيوط}

\section{Abstract}

Title: The Effect of Civic Education in the Development of Belonging, Citizenship and Social Responsibility to the kindergarten Child.

Study Destination: Faculty of Education, Assiut University.

Objectives: Developing some concepts of belonging, citizenship and bearing social responsibility to the kindergarten child.

Research Group: The current study group was limited to a group of sixty male and female children, enrolled in the first and second grades, ageing between 4 to 6 years old in the Kindergarten of AlGaddida primary school of Abnoub, Assiut governorate, at the second term of the school year, 2016.

Study Methods: The study used a semi-experimental design based on two groups; the first is experimental, while the other is the control group.

\section{Materials and Tools of the Study:}

To achieve the objectives of the study, the following tools have been prepared:

1-A questionnaire for female educators on the role of the development of belonging, citizenship and social responsibility for the kindergarten child.

2-A pictorial approach based on some concepts of belonging for the kindergarten child.

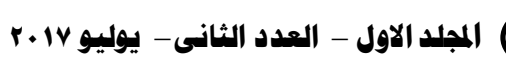


أ.د/ ماجدة هاشـم بخيت

د/ منــال أنــور ســـــ

أثر التربية المدنية فى تتمية الاتتماء والمواطنة

أ/ جمالات غيط عليوه مصطفى

3-A pictorial approach based on some concepts of citizenship for the kindergarten child.

4- A pictorial approach based on some concepts of social responsibility for the kindergarten child, prepared by Hosnia Ghonaimy, 2010.

5-Training program for the civic education to the kindergarten child.

Findings: The study have found out that there are significant statistical differences of Civic Education in relation to the development of belonging, citizenship and social responsibility to the kindergarten child in favor of the Quasi experimental group after the application of the program and this confirms the effectiveness of the suggested program.

Keywords: $\quad$ Civic $\quad$ Education-Belonging-Citizenship-Social Responsibility- Kindergarten Child

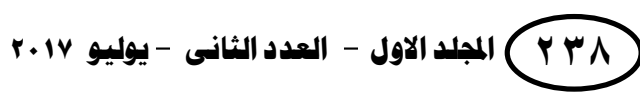




\section{المجلة العلمية لكلية رياض الاطفال -جامعة اسيوط}

\section{مقدمـــــة : مقا}

تُعد الطفولة من أهم المراحل في حياة الإنسان، إذ إنها الركيزة الأساسية لحياته وهي

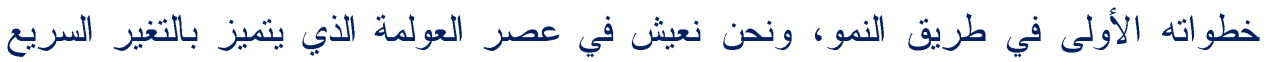

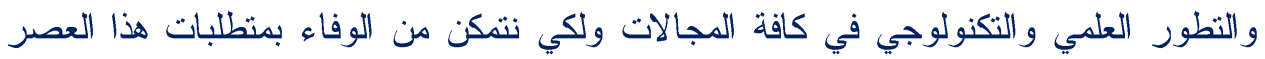

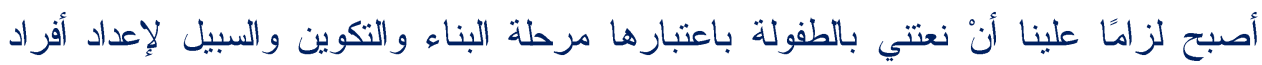

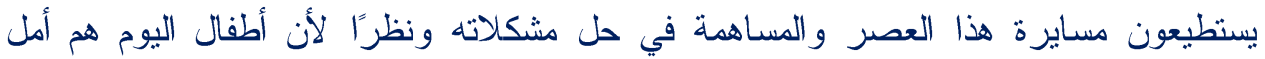
الوطن ورجال الغد المرتقب الذين سوف يتحملون مسؤولية النهوض بوطنهم في شتى مناحي الحياة، وسوف يتعاملون ويتفاعلون مع عصر المعلومات وثورة التكنولوجيا وصناعة المعرفة

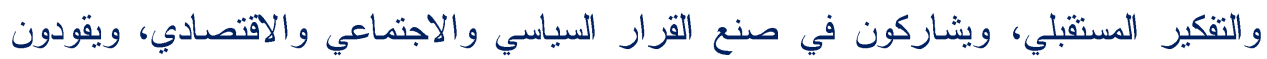

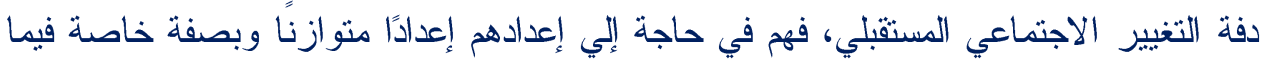
يتصل بالو لاء والانتماء للوطن وتتمية وعيهم بحاضرهم ومستقبلهم مع تعميق القيم الدينية

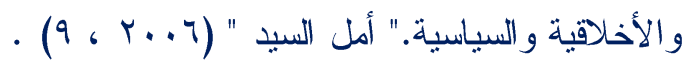

ولما كانت مرحلة رياض الأطفال أخطر مراحل النمو فى حياة الإنسان لأنها تؤثر

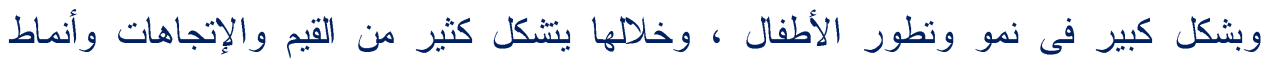

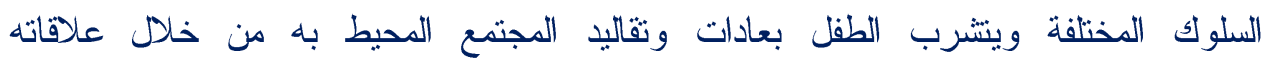
الاجتماعية بالمحيطين به لذلك فإن الطفل يحتاج إلى عون وتوجيه وإرشاد من خلال ما يقام له له من أنشطة وألعاب موجهه ليخطو بخطى ثابتة وحيوية بسنطيع من خلالها أنْ بتفتح عقله

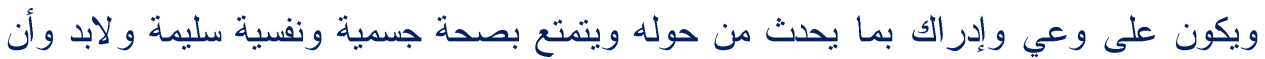
تقدم له أسلاليب التربية الهادفة البسيطة والتى تتناسب وخصائصد النمائية التى تتيز مرحلته

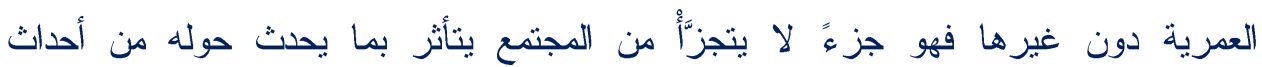
وتظورات وتقدم مذهل في شتى مجالات الحياة المختلفة .

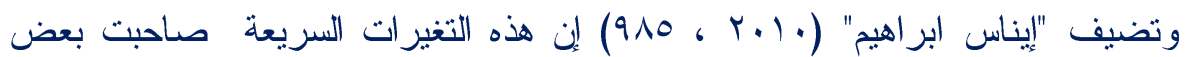

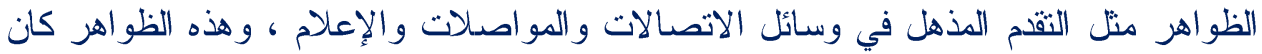

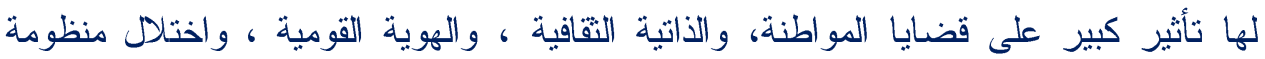

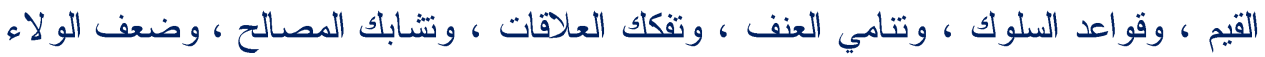
و الانتماء. 
أ.د/ ماجدة هاشـم بخيت

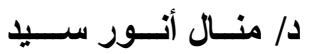

أثر التربية المدنية فى تتمية الاتتماء والمواطنة

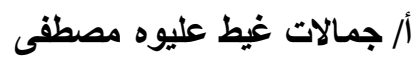

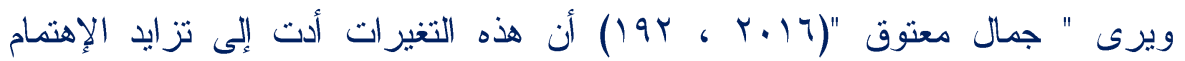

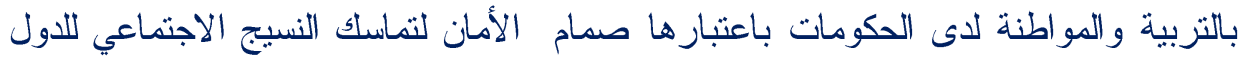

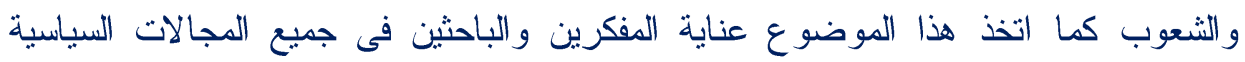
و الاجتماعية والتزبوية ، فكان لابد من إعادة النظر فى المناهج و البرامج التربوية التي تعتبر

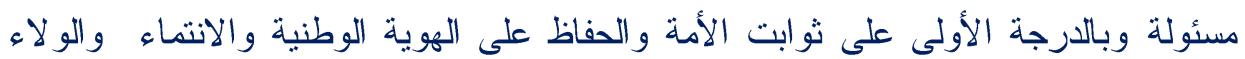
إلى الوطن وإرساء مبادئ الديمقراطية و الدساواة والعدالة والحرية وتفعيل المشاركة الإيجابية

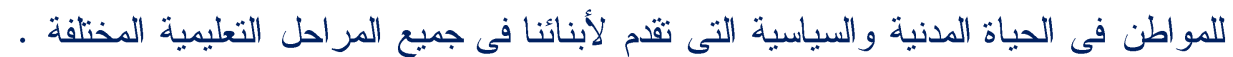

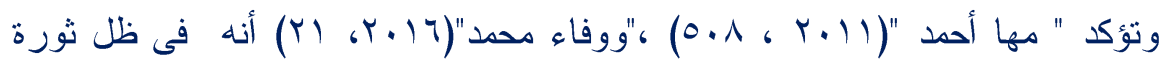

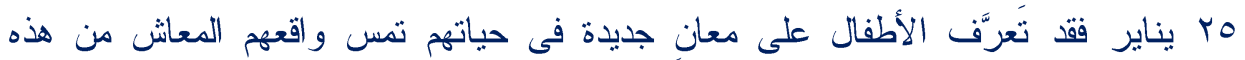

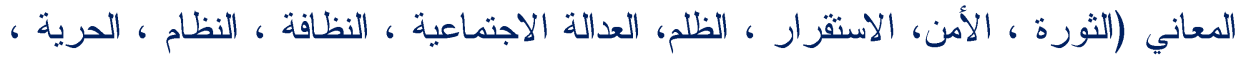

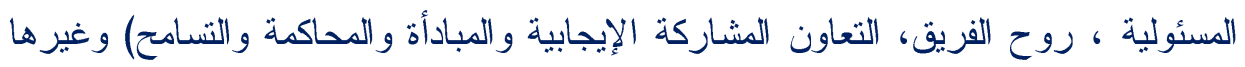

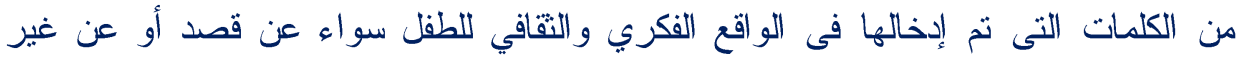

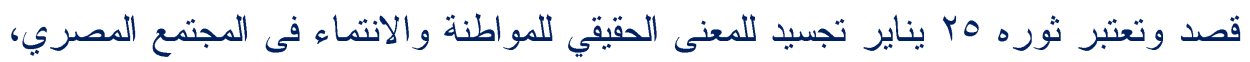

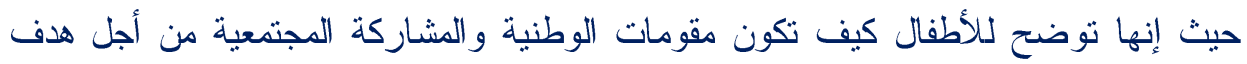
سياسي ووطني مشترك وواحد بين كل طو ائف المجتمع المصرى .

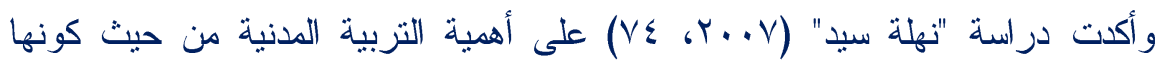

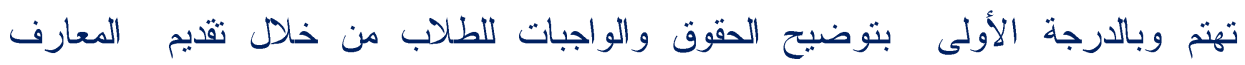
و المهارات التي تمكنهم من المشاركة بفاعلية في الحياة السياسية والمدنية في المجتمع بند

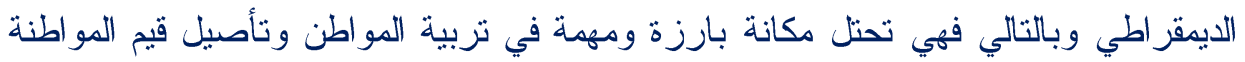

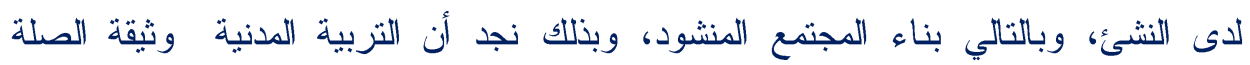
بالمو اطنة ، بل هي الأساس لبناء و إرساء مبادئها وقيمها.

ويتفق هذا مع ما اثشار إليه (2004) "Great School Staff"

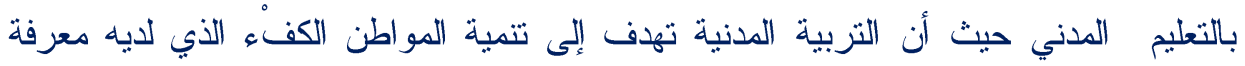

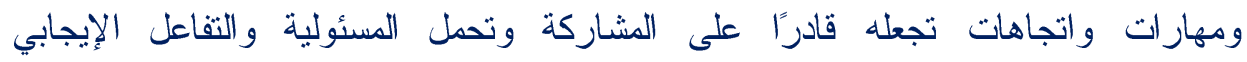
وممارسة الحياة الديمقر اطية. "وانجاته 


\section{المجلة العلمية لكلية رياض الاطفال -جامعة اسيوط}

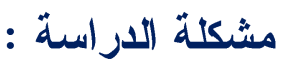

على الرغم من اهتمام الدولة ورجال التربية بإعداد الطفل إعداداً يؤهله لينشأ مواطن صالح ينهض بنفسه ويساهم فى نهضة مجتمعة ، يدين بالو لاء والانتماء لوطنة ولديه القدرة

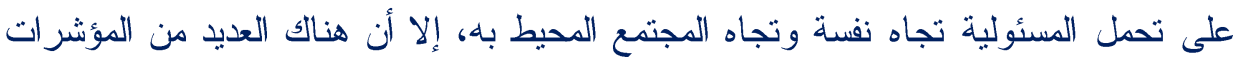

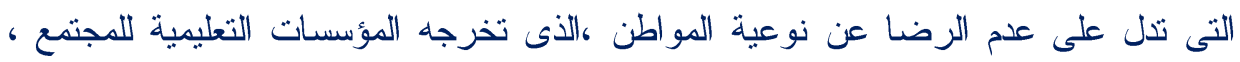

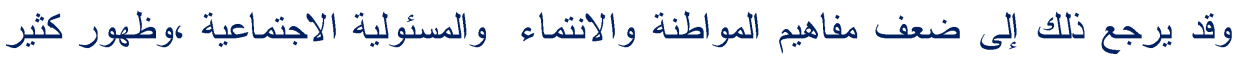

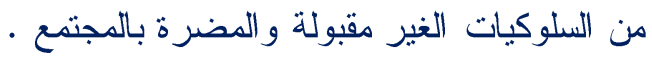

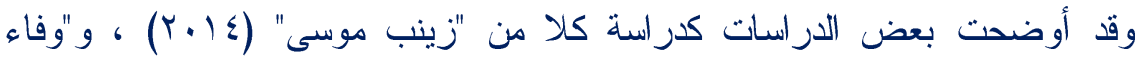
محد" (Y.17) قصورًا واضحًا فى تقديم وتوضيح مفاهيم المواطنة والانتماء للطفل وممارستها بطريقةٍ عملية بدلًا من تقديمها بطريقة نقلبدية تعتمد على التلقين والحفظ فقط

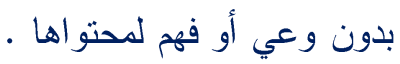

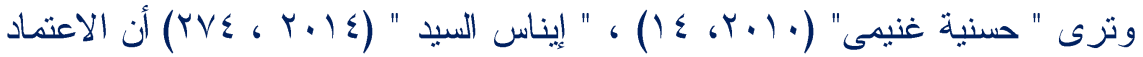

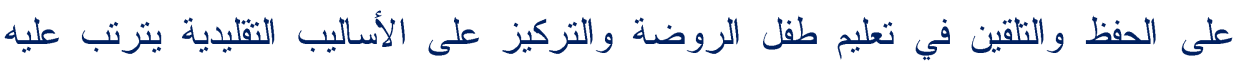

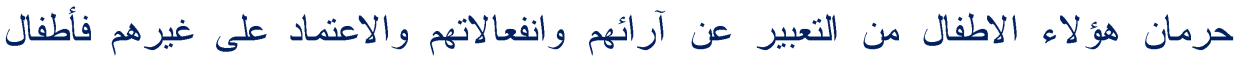

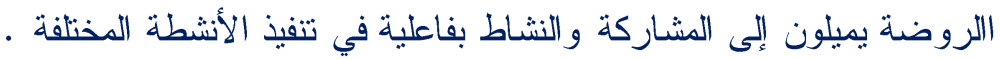

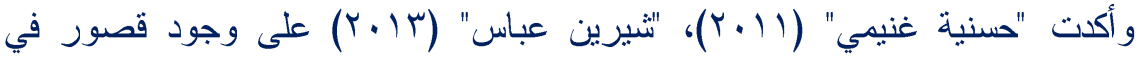
إعداد تدريبات وممارسات نعليمية خاصة بتدريب معلمات الروضة على كيفية توظيف

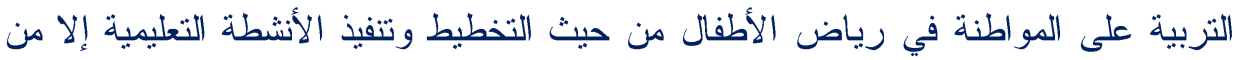
بعض الجهود الفردية لبعض المعلمات والتى لا تتعدى حيز المنقتات حول الملكية العامة

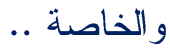

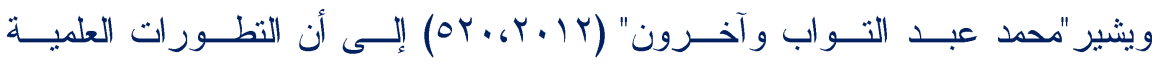

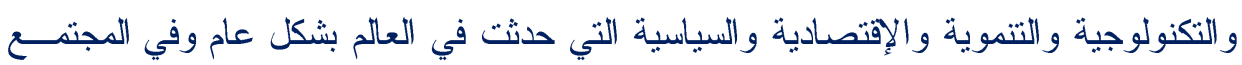

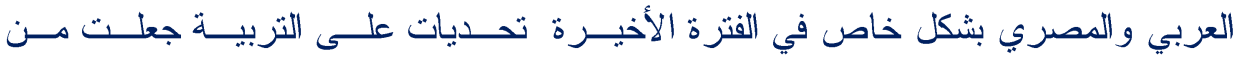

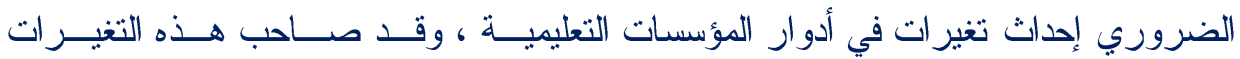
و التحديات مفاهيم وتوجهات جديدة ، من أهمها التربية الددنية وتطبيقاتها التعليمية . 
أ.د/ ماجدة هاشـم بخيت

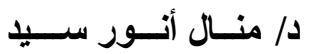

أثر التربية المدنية فى تتمية الاتتماء والمواطنة

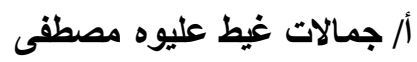

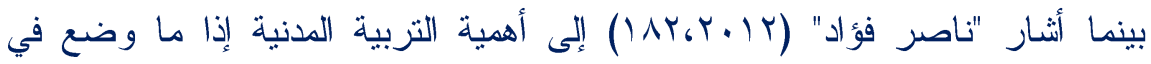

الاعتبار وجود عوامل نقافية واجنماعية وسياسية مؤثرة فيها ، منها سيادة عقلية التربية النقليدية القائمة على الأمر والنهي والزجر و والتمييز ، واعتمادها على الحفظ والتنقين أسباسًا

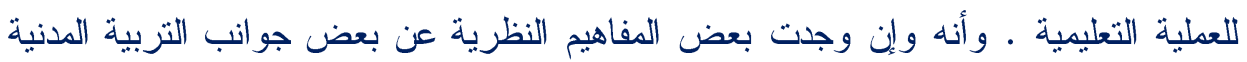

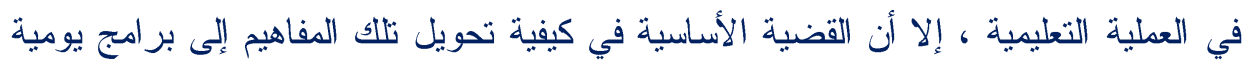

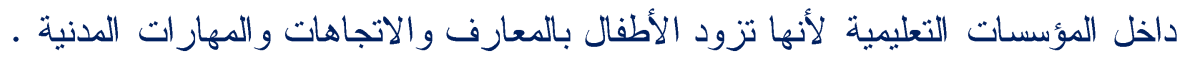
وترى الدراسة الحالية أنه فى ظل النطورات العالمية والمحلية ودعوة علماء التربية

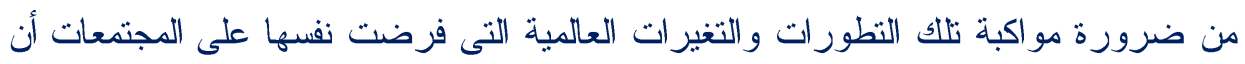

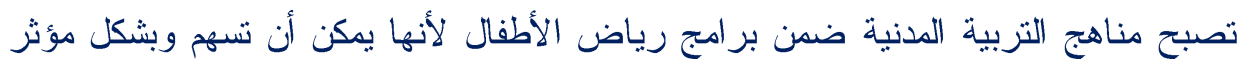

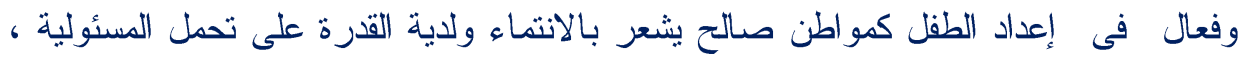
للتخفيف من حدة المشكلات التى تصاحب فقدان تلك المفاهيم، حيث تتضمن التربية الددنية

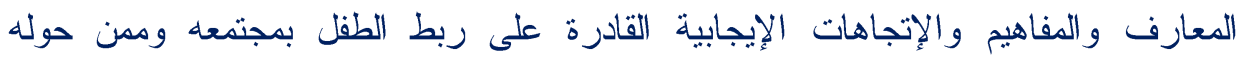
بطريقة عمليه بعيدًا عن الطرق التقليدية القائمة على الحفظ والتلقين . ولألك انبثقت مشكلة الاراسة الحالية من خلال ما يالــــي : 1- الاطِّلاع على بعض الأدبيات والبحوث و الدراسات السابقة و التي تتاولت الانتماء و أكدت

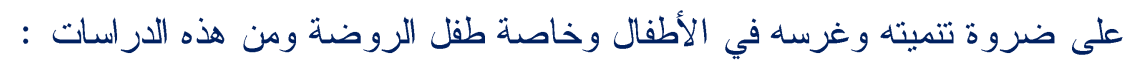

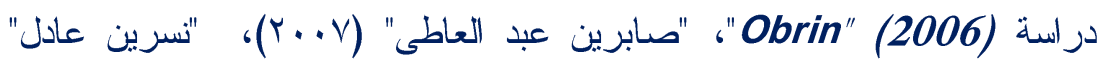
(Y..人)

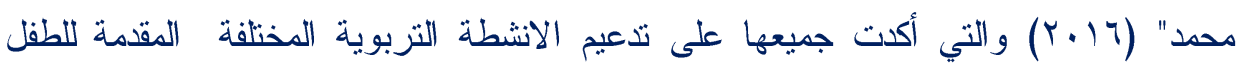
سواء كانت أنشطة متعلقة بمسرح الطفل أو انثطة موسيقية أو حركية أو باستخدام مراكز

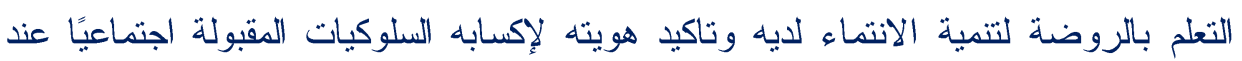

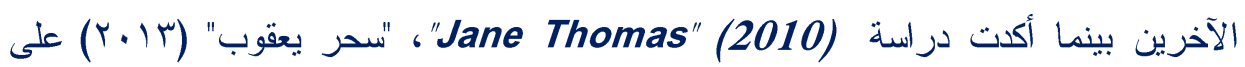

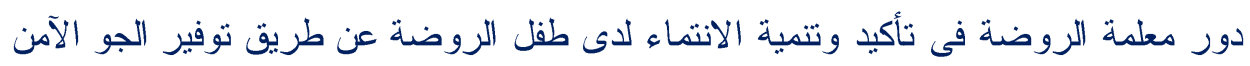

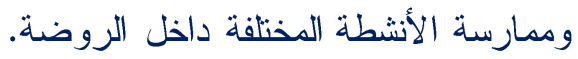




\section{المجلة العلمية لكلية رياض الاطفال -جامعة اسيوط}

ץ - الاطِّلاع على بعض الدراسات في مجال تتمية المواطنة ومنها الدراسات التالية:

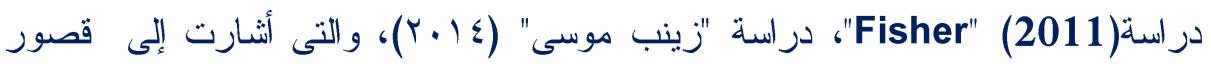

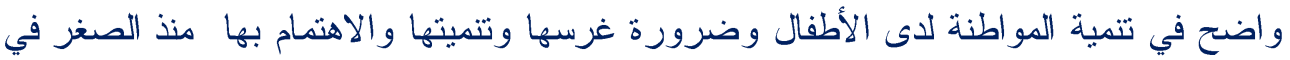
مرحلة رياض الأطفال لأن هذه المرحلة يتم تشكيل النسق القيمى للفرد خلالهها فيما بعد . كما أوضحت بعض الدراسات فاعلية استخدام استرتيجيات التعلم المختلفة لددى فاعليتها وقدرتها على غرس وتتمية المواطنة مثل استراتيجية التعلم التعاوني في تتمية الوعي بمفهوم

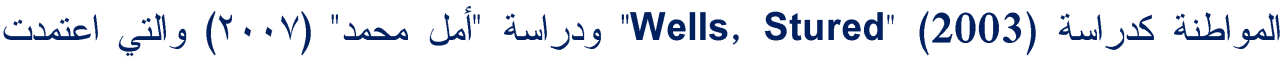

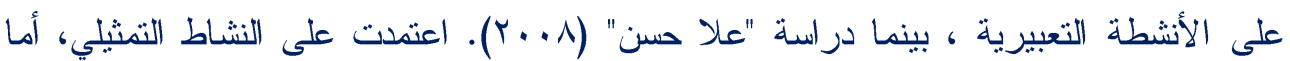

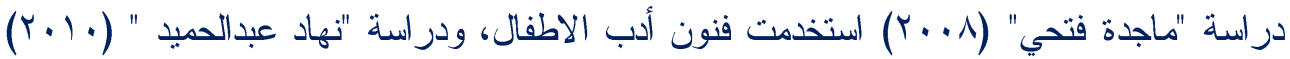
استخدامت ألعاب البناء التاريخي .

ب-الإطلاع على الدراسات السابقة التي تتاولت المسئولية الاجتماعية ومنها الدراسات التالية:

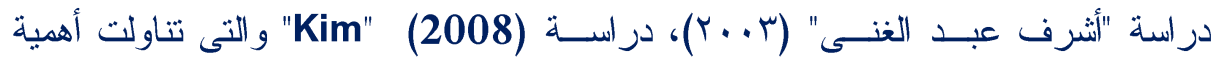

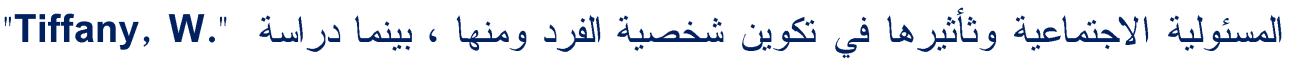

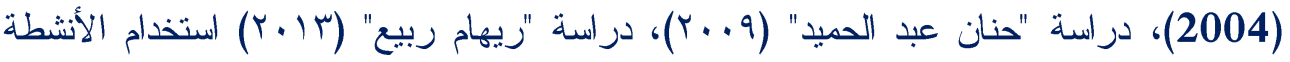

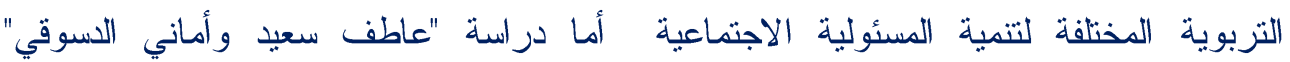
(Y. . (Y) فأكدت على أهمية التزبية المدنية بأنشطتها المختلفة في تتمية المسئولية الاجتماعية بينما

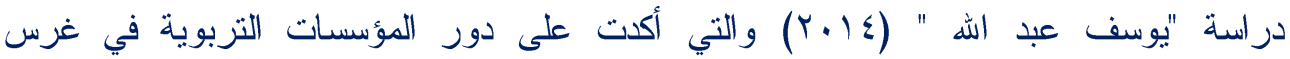
المسئولية الاجتماعية في ضوء النموذج الإسلامي .

ع -الإطِّلاع على بعض الأدبيات والبحوث و الدراسات السابقة التي تتاولت التربية الددنية ومنها

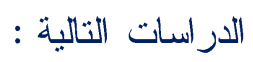

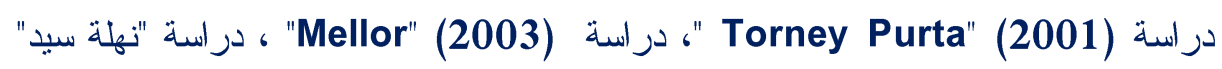

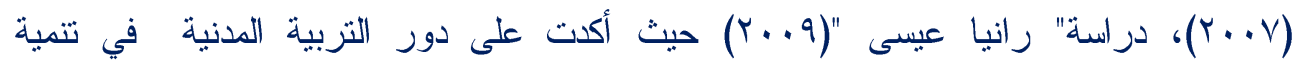

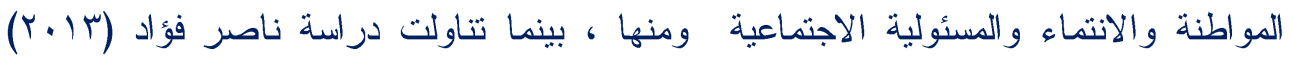
اللعب التنثيلي كاستراتيجية لتمية مفاهيم التربية المدنبة في نفوس الأطفال و أكد على أن التربية الددنية تهدف إلى تتمية المواطنة و الانتماء في نفوس الأطفال . 
أ.د/ ماجدة هاشـم بخيت

د/ منــال أنــور ســـــ

أثز التربية المدنية فى تتمية الاتتماء والمواطنة

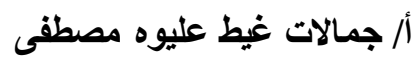

ه- الاطِّلاع على المنهج المطور (حقي ألعب وأتعلم وأبتكر) ووثثقة المعايير القومية لرياض الأطفال في مصر والتي أكدت على أهمية إكساب و تتمية قيم المواطنة

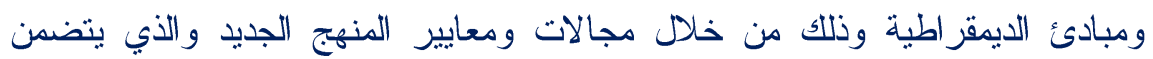
إعداد منهج شامل ومتوازن يقدم أنشطة تلبىي احتياجات الطفل الجسمية والحية والحركية و العقلية و اللغوية والاجتماعية في إطار من الترابط والتكامل لتحقيق وحدة المعرفة لتصنة

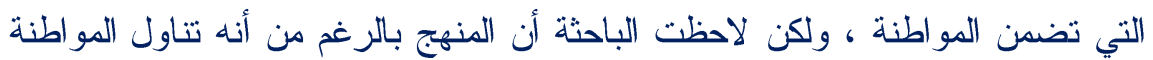

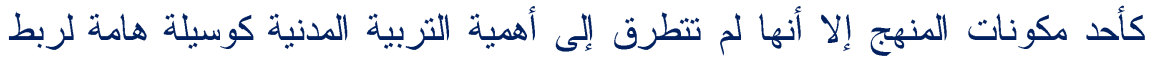

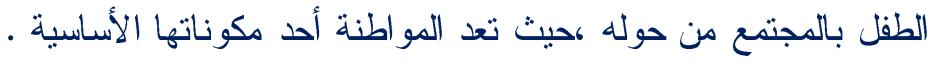
צ- كما لوحظ من خلال المتابعه للروضات بما فيهن المعلمات و أطفال الروضة الكثير من سلوكيات الأطفال والتي تل على ضلى ضعف وعيهم وممارستهم لمفاهيم المواطنة لأنة

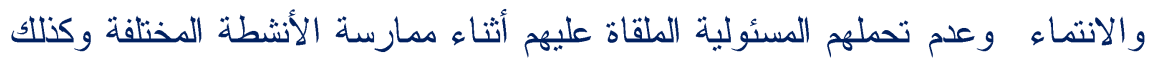
اعتماد المعلمات على الطرق التقليدية، والتركيز على الجانب الأكاديمي من تعليم

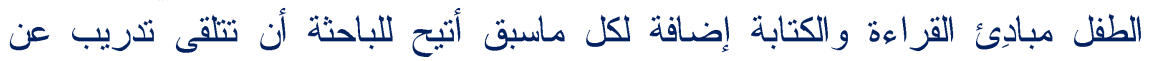

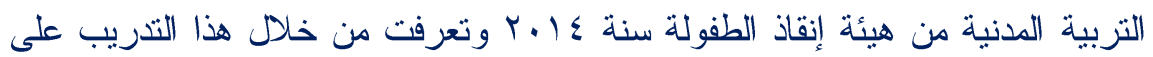
أهمية التربية المدنية في غرس مفهومي الانتماء والمواطنة ولئة المسئولية الاجتماعية لطفل الروضة ، وأهمية هذه المفاهيم لهذه المرحلة العدرية؛ لأنها تسهم في تنشئة

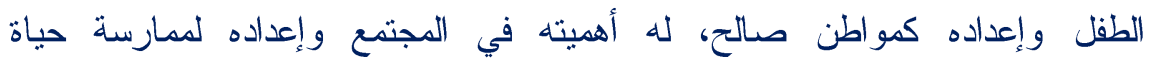

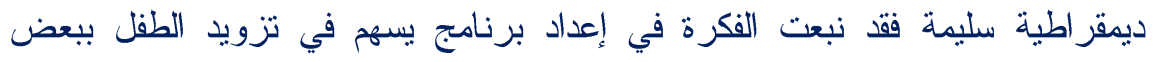

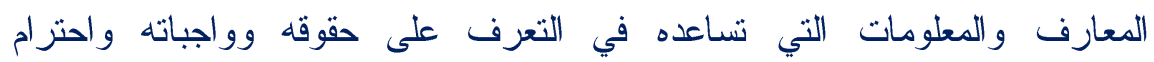
شخصيته ككيان لله أهميته في المجتمع وما عزز إحساس الباحثة بتدعيم المشكلة نتائج استطلاع الر أى الذي طبق على معلمات الروضة عن دور التربية المدنية في تتمية

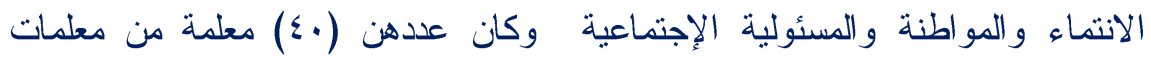
رياض الأطفال تعمل في الريف والحضر وتمثل في تحديد الأبعاد فى (احترام الملكية، ممارسة الطفل للحريات، تحمل المسئولية، المواطنة ، الديمقراطية، الانتماء، التزبية

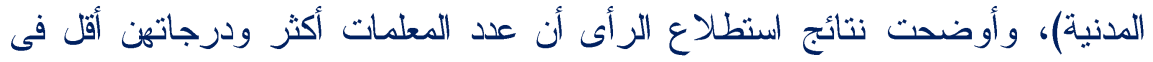
معظم أبعاد استطلاع الرأى مما يؤكد على وجود قصور فى تقديم تللك المفاهيم لطفل

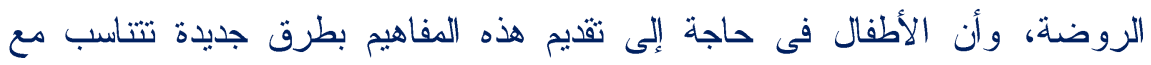

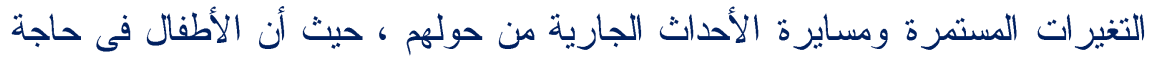
ماسة لممارسة هذه المفاهيم بطرق فعالة غير تقليدية . 


\section{المجلة العلمية لكلية رياض الاطفال -جامعة اسيوط}

ولذلك تحاول الاراسة الحالية الإجابة عن الأسئلة التالية :

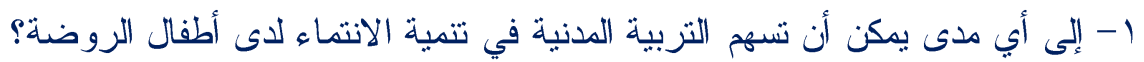

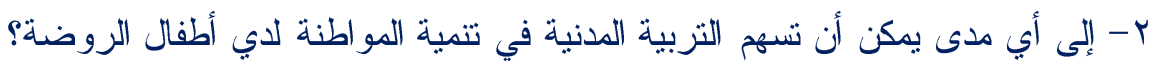
ب- إلى أي ددى يمكن أن تسهم التربية المدنية في تتمية المسئولية الاجتماعية لدي أطفال

$$
\text { الروضة؛ }
$$

أهداف الاراسة : الروفة

ا ـ التعرف على التزبية الدننية ومفهومها وأهدافها ومكوناتها و أبعادها واستر اتيجياتها ـ التها

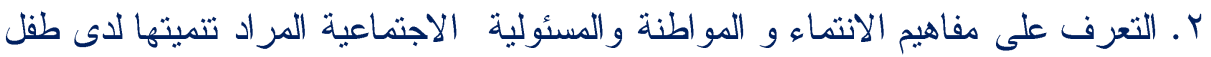

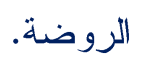

r. إعداد برنامج مقترح لتتمية بعض مفاهيم الانتماء و المواطنة و المسئولية الاجتماعية لدى طفل الروضة باستخدام التربية الددنية. ـ ـ قياس أثر البرنامج المقترح للتزبية الددنية فى تتمية بعض مفاهيم الانية لانتماء والمواطنة

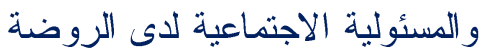

$$
\text { أهمية الار اسة : الهائ }
$$

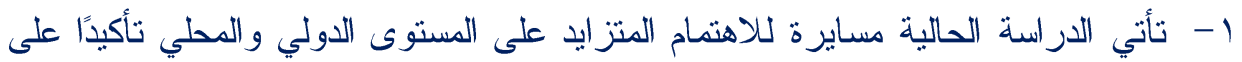

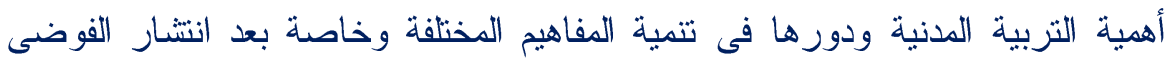

$$
\text { و أهمال القيم و الانتماء وتحمل المسئولية }
$$

r- قلة الدراسات التي تناولت المواطنة والانتماء و المسئولية الاجتماعية بإستخدام أنشطة

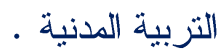
ب- ضرورة تضمين التزبية المدنية ضمن مناهج رياض الأطفال . ع - لفت انتباه القائمين والمهتمين بمرحلة رياض الأطفال إلى أهمية التربية المدنية في بناء

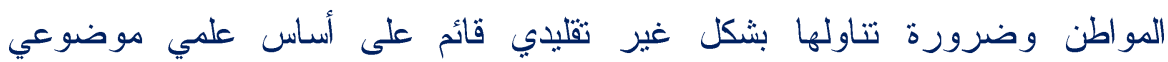
لشكلات المجتمع ،حيث أن الطفل فى هذه المرحلة يكتسب القيم والحقوق والواجبات

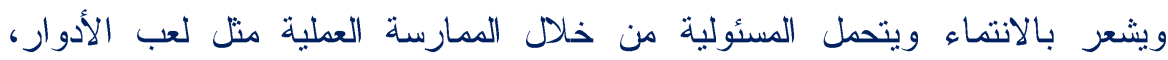

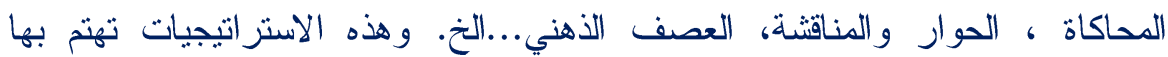
التربية الدنية بالدرجة الأولى. 
أ.د/ ماجدة هاشـم بخيت

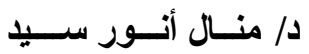

أثر التربية المدنية فى تتمية الاتتماء والمواطنة

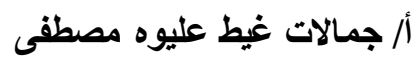

0- إعداد طفل الروضة إعدادًا يمكنه من المشاركة الإيجابية في المجتمع المدني وذلك من

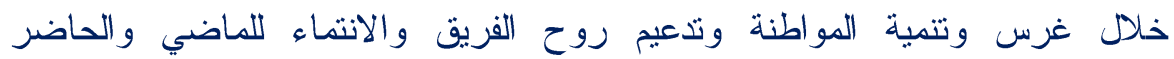

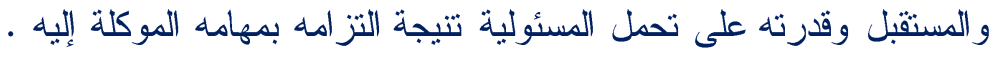

؟- فتح المجال لإجراء المزيد من الدراسات في مجال التربية المدنية وخاصة لمرحلة

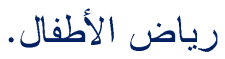

- V الأطفال ، و القائمين على ثربية الطفل من المعلمين والإعلاميين ومؤلفى كتب لبع الأطفال و الباحثين في تربية الطفل ومنتجي مطبوعات الأطفال فيما يختص بلالتربية الإعلية المدنية لأطفال الروضة.

1 - تقدم الدراسة الحالية دليًاً إرشاديًا لمعلمات الروضة لتمكنهم من تطبيق أنشطة التربية

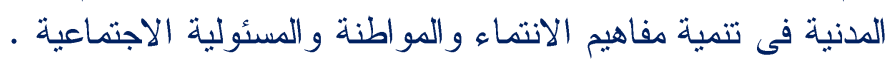

حدود الار اسة :

تتحدد الاراسة الحالية بـ

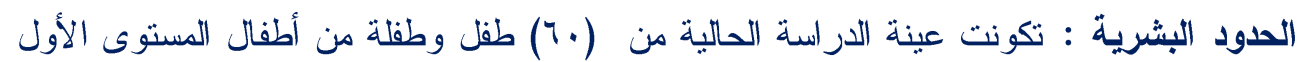

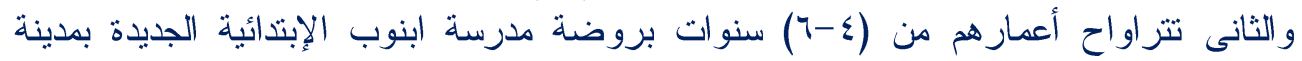
أسيوط

الحدود الزمنية: الفصل الدراسي الثاني بداية من شهر فبراير وحتى نهاية شهر ابريل 17 • كم . الحدود المكاتية : نم تطبيق البحث على عينة ممنلة من أطفال روضة مدرسة أبنوب الجديدة

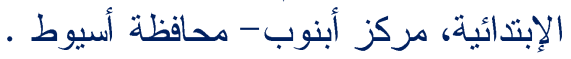

الحدود الموضوعية : اقتصرت حدود الدراسة الموضوعية على :

ا - إعداد برنامج فى التربية المدنية .

r - بعض مفاهيم الانتماء (حب الوطن، المشاركة، النظام، مساعدة الآخرين).

r- بعض مفاهيم المواطنة (احترام القانون، احترام قو اعد اللعب، احترام الآخرين و آرائهم ،

التعبير عن الرأي).

ع - تتمية مفاهيم تحمل المسئولية الاجتماعية .

و التى تضمنها برنامج فى التربية المدنية بإستخدام إستراتيجياتها و وأنشطتها المختلفة . 
أدوات الار اسة :

تم إعداد الأدوات التالية :

أ - استطلاع رأى للمعلمات للتعرف على واقع التربية المدنية ودورها في تتمية الانتماء

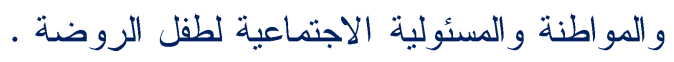

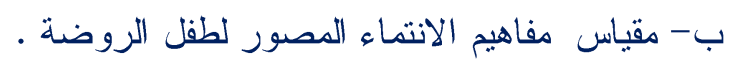

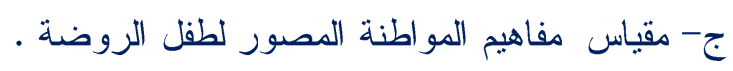

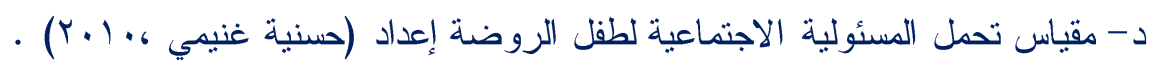

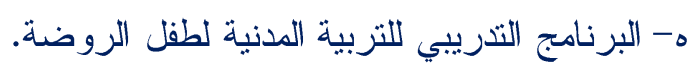

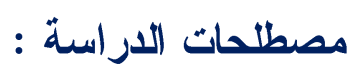

ا 1

عرفها (2007, 14

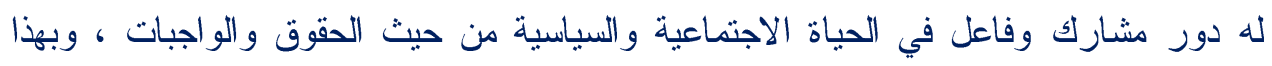

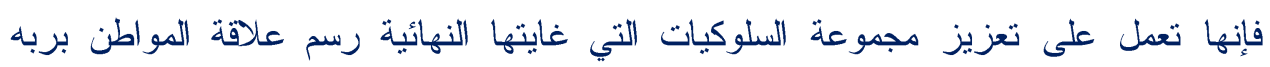

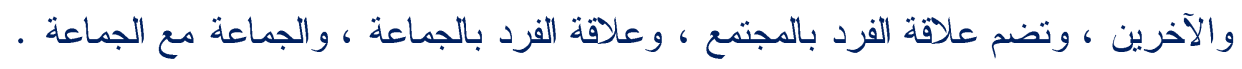

\section{التعريف الأجرائى للتربية المدنية عنية:}

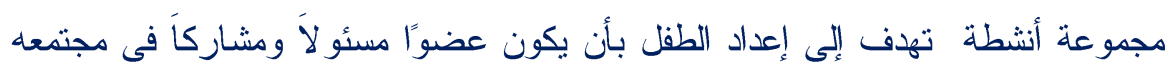
سواء كان ( داخل روضته أو الأسرة أو جماعة الرفاق) عارفًا حقوقه وو اجباته و انتمائه وو لائه لئه

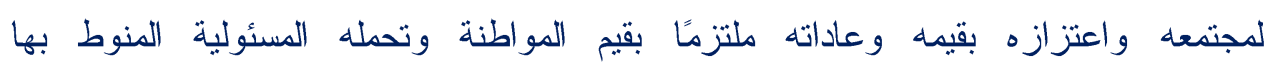

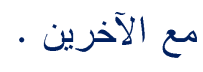

$$
\begin{aligned}
& \text { r- الإنثماء }
\end{aligned}
$$

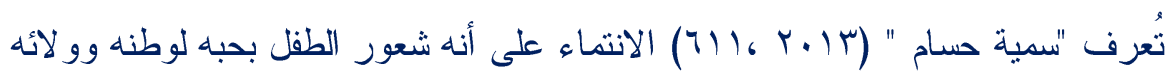

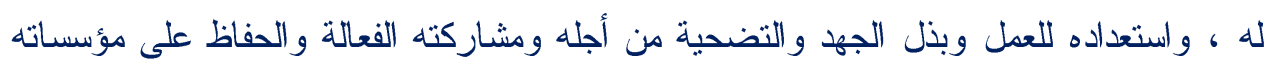

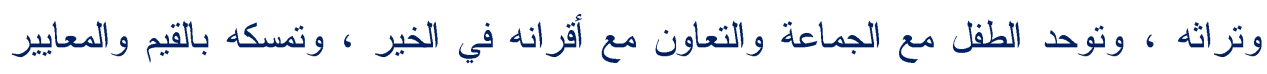

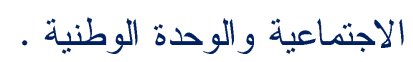


أ.د/ ماجدة هاشـم بخيت

د/ منــال أنـــور ســـــ

أثز التربية المدنية فى تتمية الاتتماء و المواطنة

أ/ جمالات غيط عليوه مصطفى مل مل

\section{التعريف الإجرائى للانتماء:}

شعور الطفل بالفخر و الرضا والإعتزاز بانتسابه لمجتمعه سواء كان ( داخل الروضه

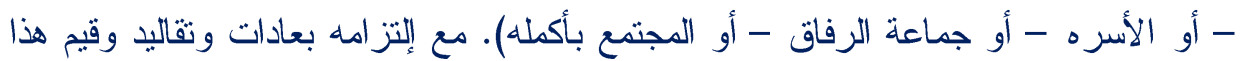

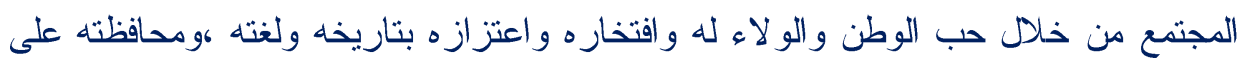
الملكيات العامة و الخاصة به ومشاركة الآخرين، ويقاس بالدرجة التى يحصل عليها الطفل فى لهى

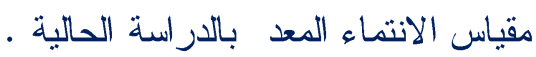
ثالثا المو اطنة :

\section{تعرف المواطنة على أنها :}

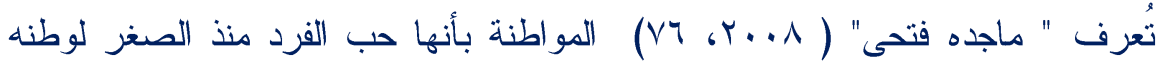
و انتمائه له ، و إلتز امه بمبادئه وقيمه وقو انينه ،و التفانى فى خدمته و الشعور بمشاكله و الإسهام الإيجابي مع غيره فى حلها . التعريف الإجرائي للمواطنة : معرفة الطقل لحقوقه وواجباته تجاه نفسه وتجاه الآخرين ،و الآتزامه فى الحفاظ على

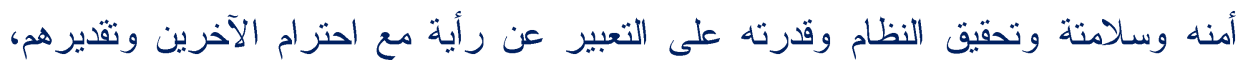
ويقاس بالدرجة التي يحصل عليها الطفل فى مقياس المواطنة المعد بالدر اسة الحالية . رابعًا: المسئولية الاجثماعية:

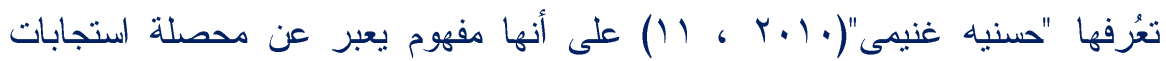
الطفل لقيامه بدور محدد نحو نفسه، ونحو أسرته، ونحو مجتمعه ، ومعرفته لحقوقه وواجباته من خلال المو اقف التي يتعرض لها. التعريف الإجرائى للمسئولية الاجتماعية : الإلتزام الذاتي و الفعلي للطفل تجاه نفسه وتجاه الجماعة ، ومحاوله فهر مشاكلها، و المشاركة معها في انجاز عمل ما ، مع الإحساس بحاجات الجماعة والجماعات الأخرى التي ينتمي إليها، ويقاس بالدرجة التى يحصل عليها الطفل فى المقياس المستخدم فى الدر اسة الحالية. 
منهج الاراسة :

استخم البحث الحالي الدنهج شبه التجريبى القائم على تصميم المجموعتين أحدها

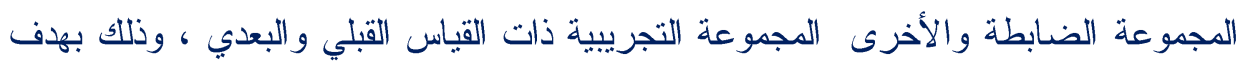

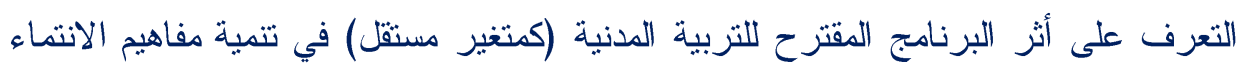

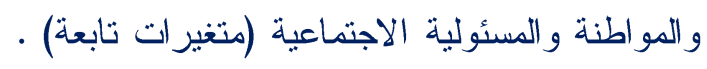

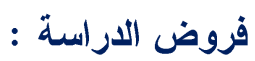

حاولت الاراسة الحالية إختبار صحة الفروض الآتية :

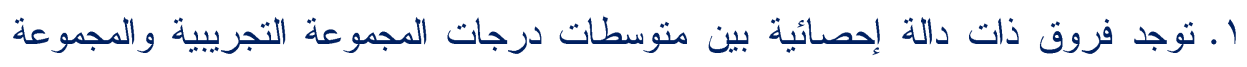

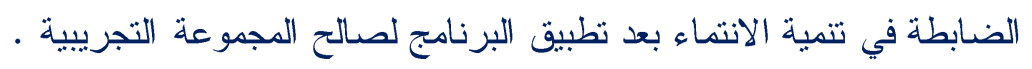

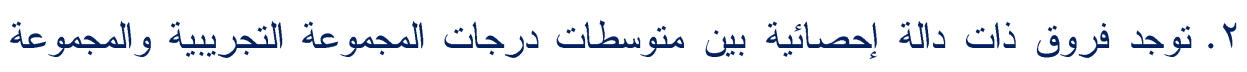

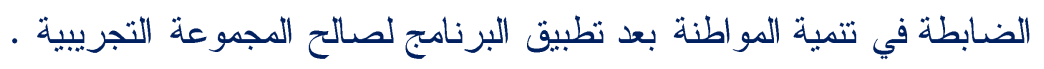

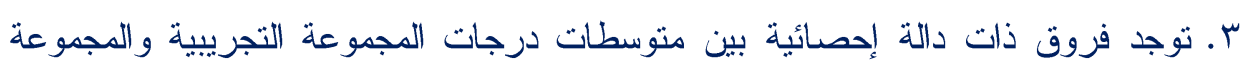
الضابطة في تنمية المسئولية الاجتماعية بعد تطبيق البرنامج لصالح المجموعة التجريبية.

$$
\begin{aligned}
& \text { خطوات واجراءات الاراسة : } \\
& \text { الطريقة والإجراءات : }
\end{aligned}
$$

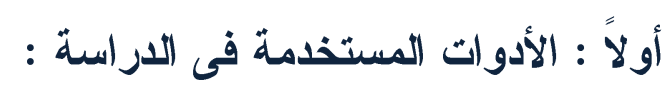

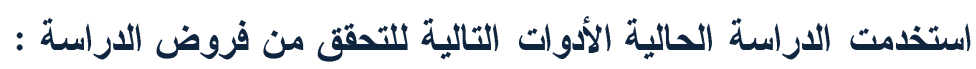

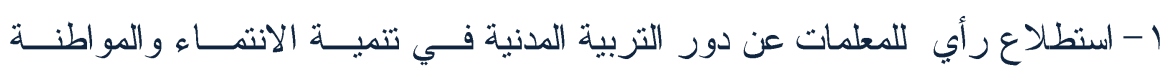

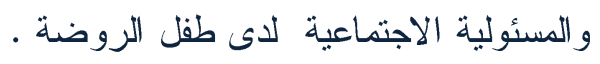
الهيف من استطلاع الرأى : الاجئ

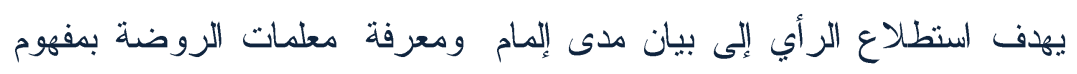

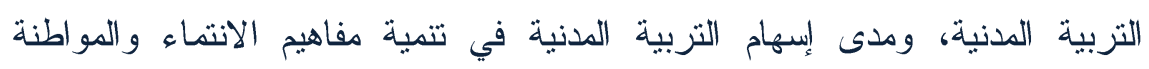

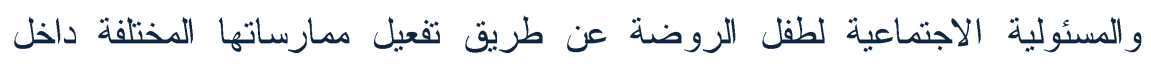

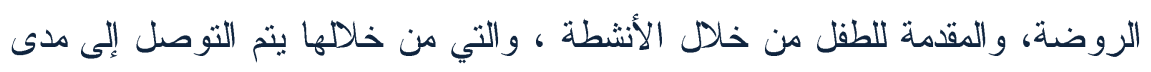

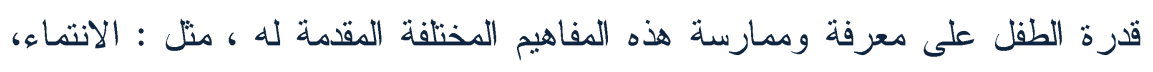

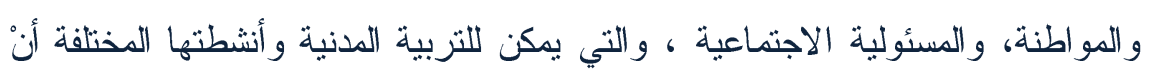

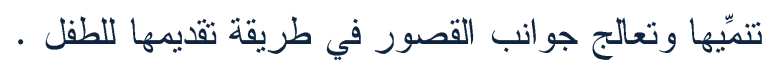


أ.د/ ماجدة هاشـم بخيت

د/ منــال أنـــور ســـــ

أثر التربية المدنية فى تتمية الاتتماء و المواطنة

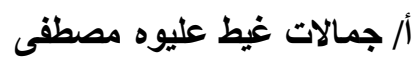

وصف استطلاع الرأي:

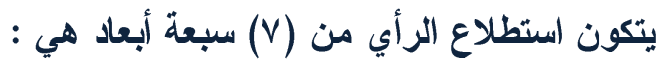

احترام الملكية ، ممارسة الطفل للحريات ، تحمل المسئولية ،المواطنة ، الانتماء،

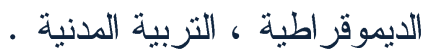

وكل" بُعد من الأبعاد السابقة يتكون من عدد من العبارات مدون أمامها ثلاث استجابات

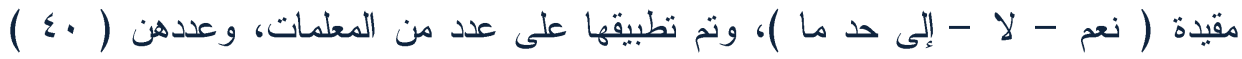

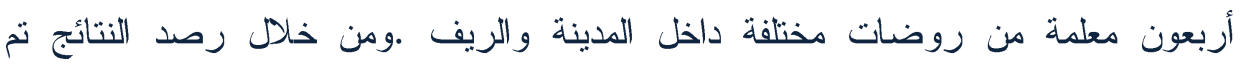

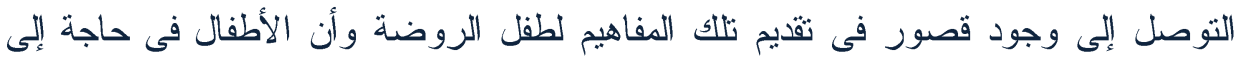
تقديم هذه المفاهيم بطرق جديدة نتتاسب مع التغيرات المستمرة ومسايرة الأحداث الجارية من

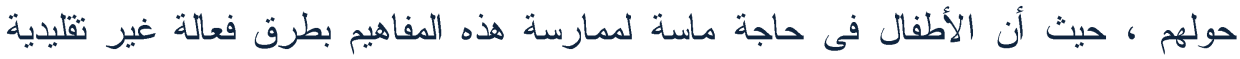

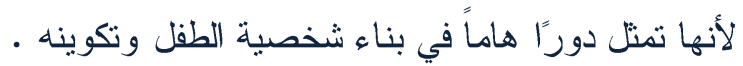
r- مقياس مفاهيم الانتماء المصور لطفل الروضة . تحديد الهاف من المقياس :

يهذف المقياس إلى التعرف على مستوى نمو مفاهيم الانتماء لطفل الروضة باستخدام

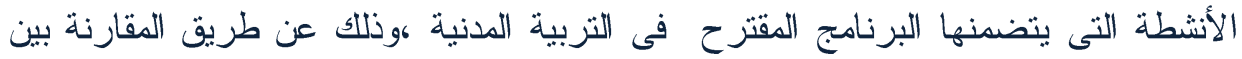

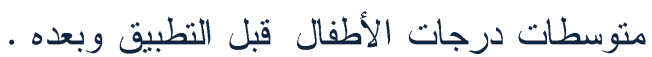
يتضمن هذا المقياس أربعة ابعاد هى : ( حب الوطن - المشاركة - النظام - مساعدة وبلة هيل

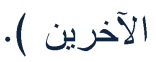

\section{إعداد الصورة الأولية للمقياس :}

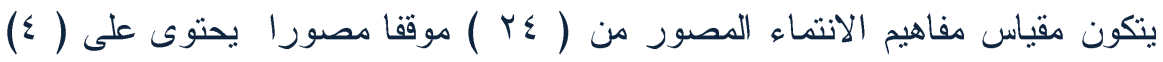

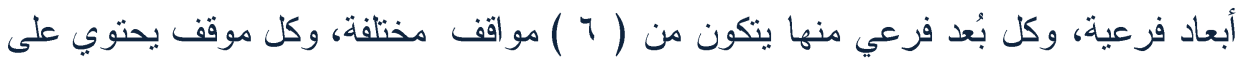
بديلين مصورين يعبران عن الموقف نفسه، وبذلك يشتمل المقياس ككل على بلى ( بديًاً مصورًا. 


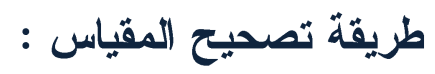

روعي عند تصحيح المقياس أن تعطي درجة واحدة لكل سؤال في حالة الإجابة

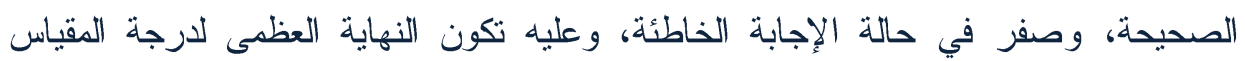

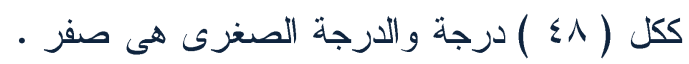

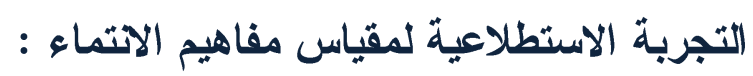

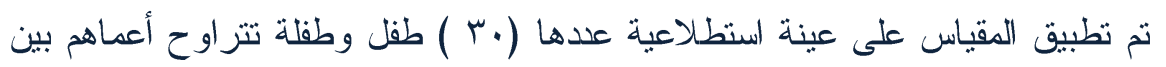

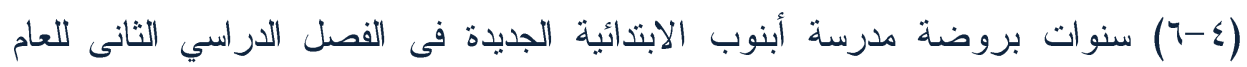

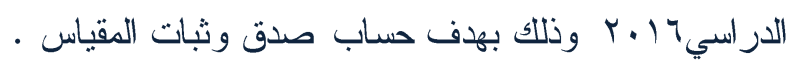

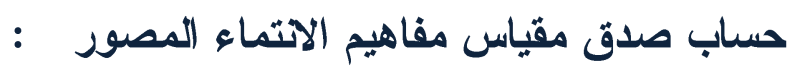

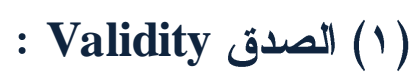

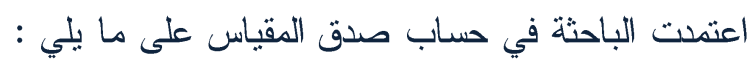

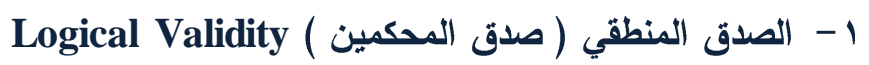

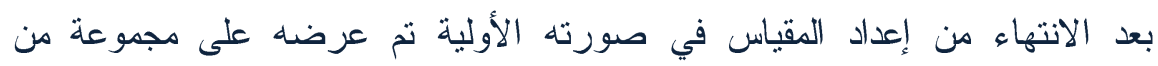
المحكمين (IV) محكماً من المناهج وطرق التدريس بكلية التربية جامعة أسيوط وكلية التزبية جامعة سوهاج ، وتربية الطفل بكلية رياض الاطفال جامعة أسيوط وكلية البنات جامعة عين لئل

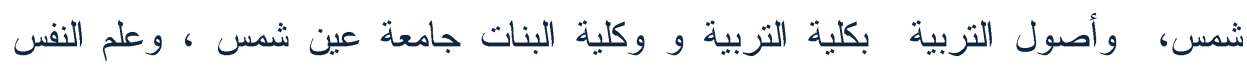

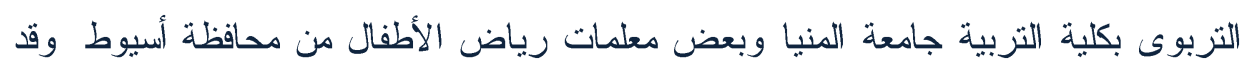

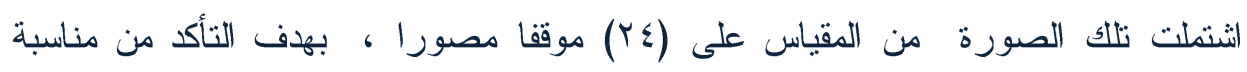

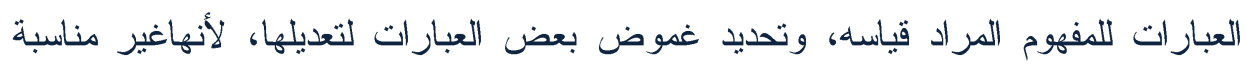

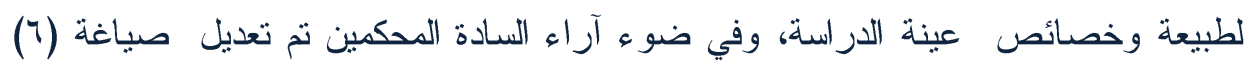

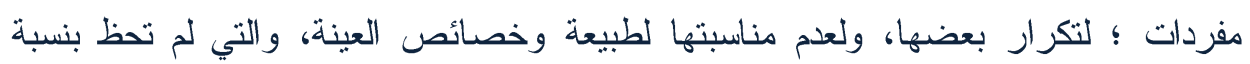

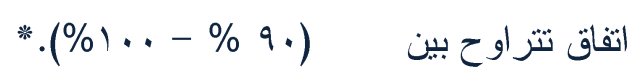

أصبح مقياس الانتماء بعد تعديل العبارت التي لم تحظ بنسبة اتفاق تنتراوح بين

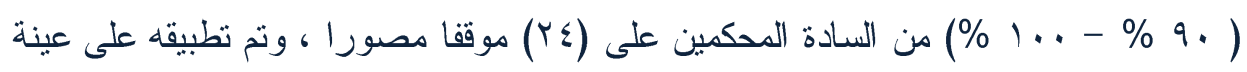
الدراسة الاستطلاعية للاستقرار على الصورة النهائية للمقياس. 
أ.د/ ماجدة هاشـم بخيت

د/ منــال أنــور ســـــ

أثر التربية المدنية فى تتمية الاتتماء والمواطنة

أ/ جمالات غيط عليوه مصطفى مل مل

r

ويتم حساب الصدق التمييزي عن طريق حساب دلالة الفروق بين الإزبــاعي الأعلـى

و الإرباعي الأدني لدرجات الطلاب في المقياس، وتم حساب دلالة الفــروق بــين الإزبــاعي

الأعلى و الأدنى عن طريق حساب اختبار مان ويتتي لد لالة الفروق بين العينات اللابار امتريـــة المستقلة، وجدول (1) يوضت ولك للك.

جلول (1)

متوسط ومجموع الرتب وقيمة Z ومستوى الالالة

\begin{tabular}{|c|c|c|c|c|c|}
\hline الالامة & قيمة & مجموع الرثب & متوسط الرتب & العـد & المجموعة \\
\hline \multirow[t]{2}{*}{ دال عند +.. } & \multirow[t]{2}{*}{$0 . v$} & $\wedge \varepsilon . \Sigma \wedge$ & $1 . .07$ & $\wedge$ & دنبا \\
\hline & & Tr. & TV.O & $\wedge$ & عليا \\
\hline
\end{tabular}

يتضح من جدول (1) قيمة z دالة عند مستوى دلالة ا +...مدا يؤكد ارتةــاع الصــدق

التمييزي لمقياس مفاهيم الانتماء - التهاء

: Reliability الثبات (r)

حساب ثبات مقياس مفاهيم الانتماء المصور

: Alpha Cronbach Method طريقة ألفا كرونباك -

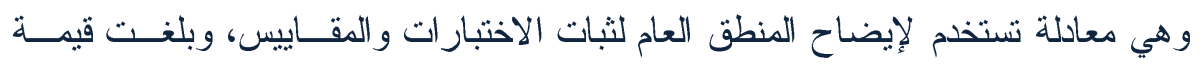

معامل ثبات المقياس س.^.. · ، و هي قيمة مرتفعة تدل على ثبات المقياس .

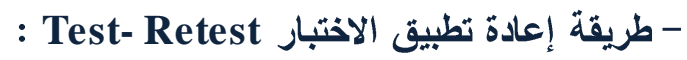

استخدمت طريقة إعادة الاختبار لحساب ثبات المقياس بعد تطبيقه على العينة

الاستطلاعية، بفاصل زمني أسبوعين بين التطبيق الأول والتطبيق الثاني، وتم حساب معامل الارتباط بين درجات الطلاب في التطبيق الأول ودرجاتهم في التطبيق الثاني على المقياس ككل، وبلغ معامل بيرسون 901. . ، وهي قيمة مرتفعة تدل على ثبات المقياس. 
- التجزئة النصفية لفقرات المقياس:

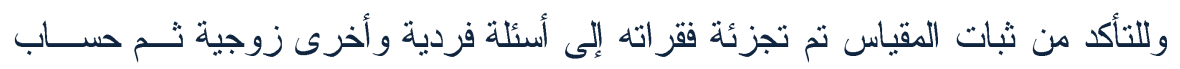

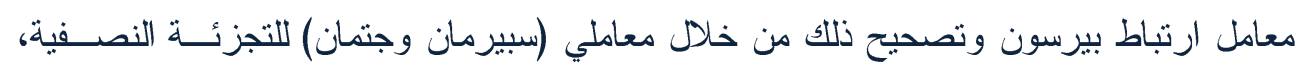

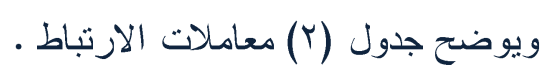

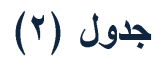

معاملات التجزئة النصفية لمقياس الآتماء ( ن = ب )

\begin{tabular}{|c|c|c|c|}
\hline اللالاة & معامل جتمان & معامل سبيرمان & الخواص \\
\hline$\ldots 1$ & . Avq & .90. & المقياس \\
\hline
\end{tabular}

زمن تطبيق المقياس :

تم تقدير زمن المقياس قى ضوء الملاحظات ومراقبة أداء الأطفال فى ضوء التجربة

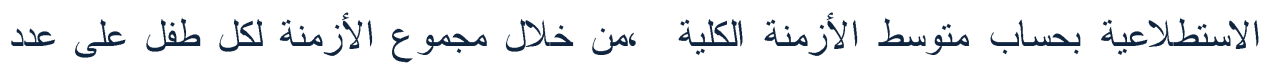
الاطفال وبلغ زمن المقياس (10) دقيقة تقريبا .

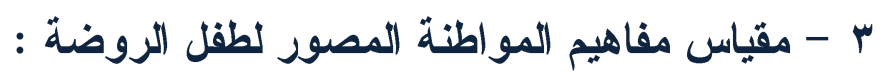
تحليد الهذف من المقياس :

يهدف المقياس إلى التعرف على مستوى نمو مفاهيم المواطنة لطفل الروضة باستخدام

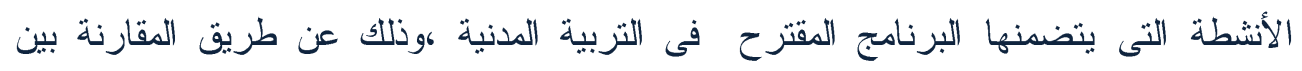

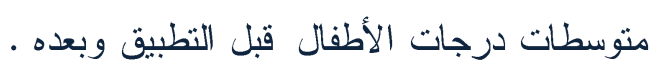
يتضمن هذا المقياس أربعة ابعاد هى ( احترام القانون - احترام قواعد اللعب - احترام

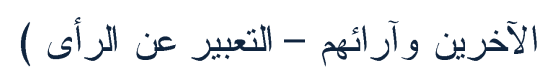

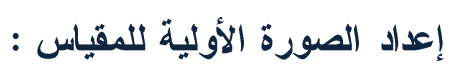

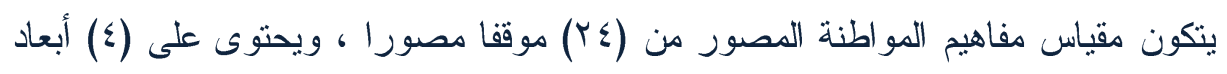

فرعية، وكل بُعد فرعي منها يتكون من ( T ) مواقف مختلفة، وكل موقف يحتوي على بديلين

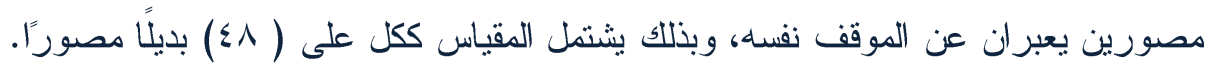


أ.د/ ماجدة هاشـم بخيت

د/ منــال أنــور ســـــ

أثر التربية المدنية فى تتمية الاتتماء والمواطنة

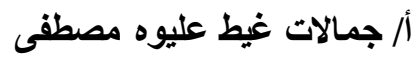

- طريقة تصحيح المقياس :

روعي عند تصحيح المقياس أن تعطي درجة واحدة لكل سؤال في حالة الإجابة الصحيحة، وصفر في حالة الإجابة الخاطئة، وعليه تكون النهاية العظمى لدرجة المقياس

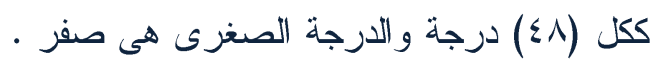

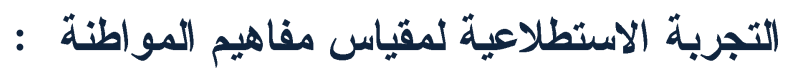

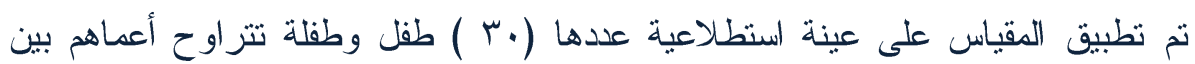

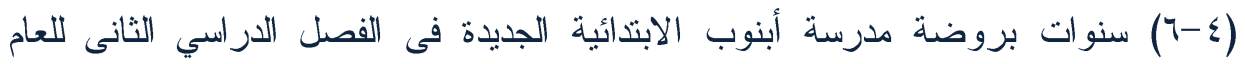

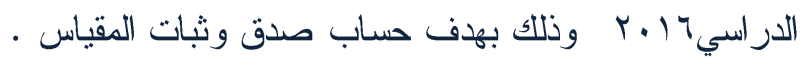

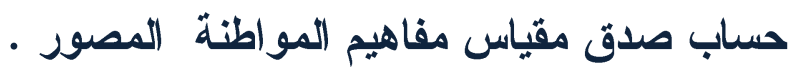

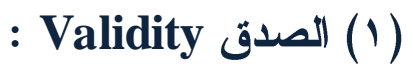

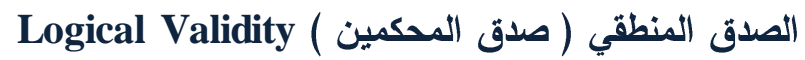
بعد الانتهاء من إعداد المقياس في صورته الأولية نم عرضه على على مجموعة من المحكمين (IV) محكمًا من المناهج وطرق التذريس بكلية التربية جامعة أسيوط وكلية التربية جامعة سوهاج ، وتربية الطفل بكلية رياض الاطفال جامعة أسيوط وكلية البنات جامعة عين

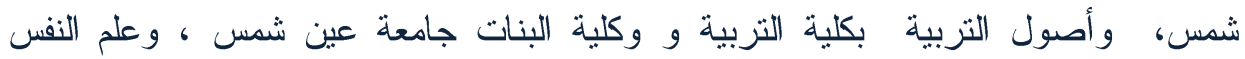

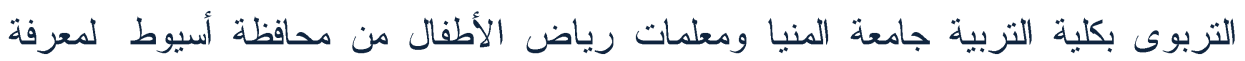

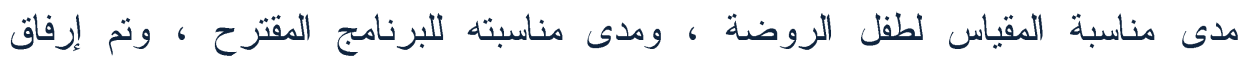

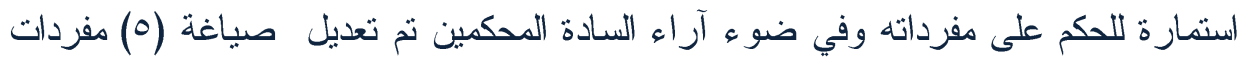

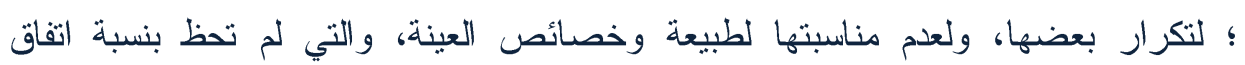

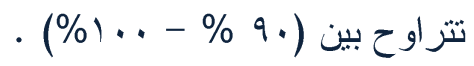
أصبح مقياس مفاهيم المواطنة بعد تعديل العبارت التي لم تحظ بنسبة انفاق نتزاوح

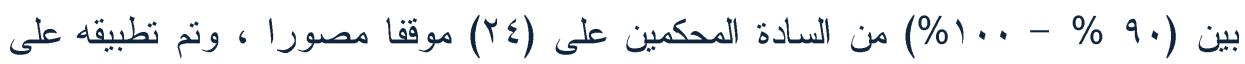
عينة الدراسة الاستطلاعية للاستقرار على الصورة النهائية للمقياس. 
الصدق التمبيزي:

ويتم حساب الصدق التمبيزي عن طريق حساب دلالة الفروق بـين الإربــاعي الأعلـى و الإرباعي الأدني لدرجات الطلاب في المقياس، وتم حساب دلالة الفــروق بــين الإزبــاعي

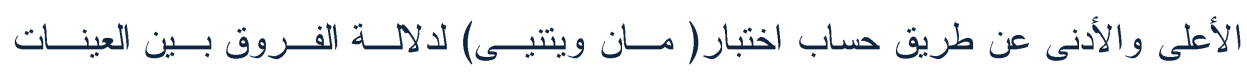

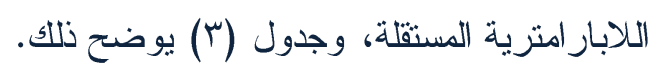

جدول (r)

متوسط ومجموع الرتب وقيمة Z ومستوى الالالة

\begin{tabular}{|c|c|c|c|c|c|}
\hline الالاكة & قيمة & مجموع الرتب & متوسط الرتب & العدد & المجموعة \\
\hline \multirow{2}{*}{ 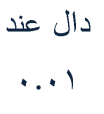 } & \multirow[t]{2}{*}{0.11} & $\wedge \varepsilon . \varepsilon$ & 1.00 & $\wedge$ & دنبا \\
\hline & & TYE & rᄉ & $\wedge$ & عليا \\
\hline
\end{tabular}

$$
\text { يتضح من جلول (r) : }
$$

قيمة z دالة عند مستوى دلالة ا . .. مدا يؤكد ارتفاع الصدق التمبيزي لمقياس المواطنة.

: Reliability الثبات (r)

\section{: Alpha Cronbach Method طريقة (ألفا كرونباك) -}

وهي معادلة نستخدم لإيضاح المنطق العام لثبات الاختبارات و المقاييس، وبلغت قيمة

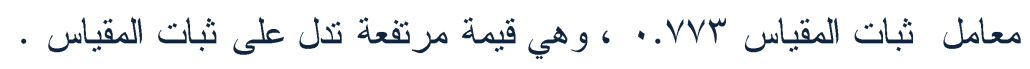

- Test- Retest طريقة إعادة تطبيق الاختبار

أُستخدمت طريقة إعادة الاختبار لحساب ثبات المقياس بعد تطبيقه على العينة : لإن

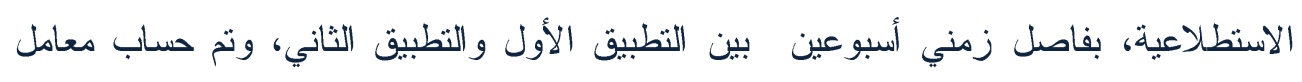
الارتباط بين درجات الطلاب في التطبيق الأول ودرجاتهم في التطبيق الثاني على المقياس ككل، وبلغ معامل بيرسون 9 ، 9. •، وهي قيمة مرتفعة تذل على ثبات المقياس. - التجزئة النصفية لفقرات المقياس: ليزئ وللتأكد من ثبات المقياس تم تجزئة فقراته إلى أسئلة فردية وأخرى زوجية ثم حساب معامل ارتباط بيرسون وتصحيح ذلك من خلال معاملي (سبيرمان وجتمان) للتجزئة النصفية، ويوضح جدول (ع) معاملات الارتباط . 
أ.د/ ماجدة هاشـم بخيت

د/ منــال أنــور ســـــ

أثر التربية المدنية فى تتمية الاتتماء والمواطنة

أ/ جمالات غيط عليوه مصطفى مل مل

جدول (๕)

معاملات التجزئة النصفية لمقياس المواطنة ( ن = • ب )

\begin{tabular}{|c|c|c|c|}
\hline الالالة & معامل جتمان & معامل سبيرمان & الخو اص \\
\hline$\ldots+1$ & .1197 & $.9 \leq 1$ & المقياس \\
\hline
\end{tabular}

: (v) (انضح من جدول

أنّ معاملات الارتباط دالة عند مستوى 1 .... وذللك يؤكد على ثبات المقياس

زمن تطبيق المقياس :

تم تقدير زمن المقياس قى ضوء الملاحظات ومراقبة أداء الأطفال فى ضوء

التجربة الاستطلاعية بحساب متوسط الأزمنة الكلية هن خلال مجموع الأزمنة لكل طفل على عدد الاطفال وبلغ زمن المقياس 10 دقيقة تقريبا . ب - مقياس تحمل المسئولية الإجتماعية المصور إعداد (حسنية غنيمى عبا

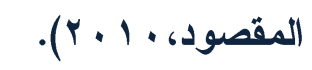

الاهدف من المقياس :

قياس مدى فهم الطفل لتحمل المسئولية الإجتماعية .

مكونات المقياس :

يتكون المقياس من (乏乏) صورة، وهذه الصور معبرة عن موقف ما ، والصور بها

ثلاث مواقف، موقف إيجابى، موقف سلبى، موقف وسط بين الاثثين، وعلى الطفل أن يختار

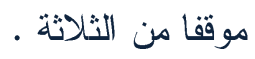

ويتكون المقياس من ثلاثة أبعاد رئيسية :(المشاركة، آداب السلوك، الاعتماد على النفس)

طريقة تصحيح المقياس:

الموقف الذى يظهر فيه الطفل متحملا للمسئولية يأخد (r) .

الموقف الذى يظهر فيه عدم تحمل المسئولية يأخد (1) .

الموقف الوسط يأخد (r) •

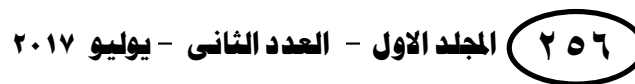




\section{المجلة العلمية لكلية رياض الاطفال -جامعة اسيوط}

التجربة الاستطلاعية لمقياس تحمل المسئولية الإجتماعية : تم تطبيق المقياس على عينة استطلاعية عددها (·ץ ) طفل وطفلة تتراوح أعماهم من

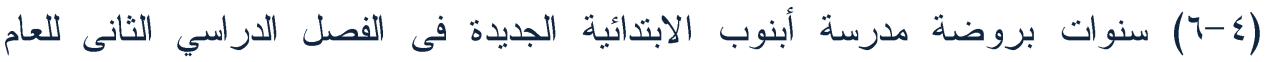
الدراسي 17 . r وذلك بهذف حساب صدق وثبات المقياس فى الدراسة الحالية :

\section{: Validity الصدق (1)}

\section{اعتمدت الدراسة الحالية في حساب صدق المقياس على ما يلي :}

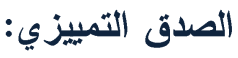

ويتم حساب الصدق التمييزي عن طريق حساب دلالة الفروق بين الإرباعي الأعلى

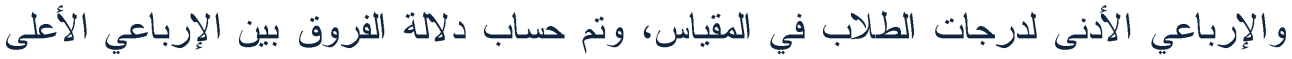

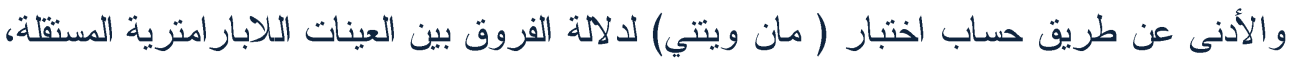

$$
\text { وجدول (0) يوضح ذللك. }
$$

جدول (0)

متوسط ومجموع الرتب وقيمة Z ومستوى الالالة

\begin{tabular}{|c|c|c|c|c|c|}
\hline الالالة & قيمة & مجموع الرتب & متوسط الرتب & العدد & المجموعة \\
\hline \multirow[t]{2}{*}{ دال عند ا •.. } & \multirow[t]{2}{*}{$\varepsilon .0 \mathrm{~V}$} & $7 \wedge$ & 1.0 & $\wedge$ & دنبا \\
\hline & & $19 r$ & $r \varepsilon$ & $\wedge$ & عليا \\
\hline
\end{tabular}

يتضح من جدول (0) : قيمة Z دالة عند مستوى دلالة ا...•مما يؤكد ارتفاع

الصدق التمييزي لمقياس تحمل المسئولية الاجتماعية.

r Reliability حساب ثبات المقياس

: Alpha Cronbach Method طريقة ألفا كرونبابك

وهي معادلة تستخدم لإيضاح المنطق العام لثبات الاختبارات والمقاييس، وبلغت قيمة

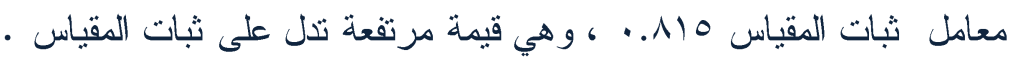
طريقة إعادة تطبيق الاختبار Test- Retest

تم إستخدام طريقة إعادة الاختبار لحساب ثبات الدقياس بعد تطبيقه على العينة

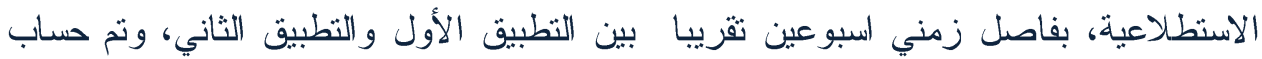
معامل الارتباط بين درجات الطلاب في التطبيق الأول ودرجاتهم في النطبيق الثاني على لانى الكقياس ككل، وبلغ معامل بيرسون 9V0.9.، وهي قيمة مرتفعة تدل على ثبات الكقياس. 
أ.د/ ماجدة هاشـم بخيت

د/ منــال أنـــور ســـــ

أثز التربية المدنية فى تتمية الاتتماء والمواطنة

أ/ جمالات غيط عليوه مصطقى ملرد

التجزئة النصفية لفقرات المقياس:

وللتأكد من ثبات المقياس تم تجزئة فقراته إلى أسئة فردية وأخرى زوجية، ثم

حساب معامل ارتباط بيرسون، وتصحيح ذلك من خلال معاملي( سبيرمان وجتمان) للتجزئة

النصفية، ويوضح جدول (آ) معاملات الارتباط .

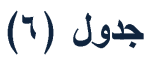

معاملات التجزئة النصفية لمقياس المسئولية الاجتماعية ( ن = . ب )

\begin{tabular}{|c|c|c|c|}
\hline الدلامة & معامل جتمان & معامل سبيرمان & الخو اص \\
\hline$\ldots+1$ & $\cdot . \wedge \wedge q$ & .199. & المقباس \\
\hline
\end{tabular}

يتضح من جدول (T) أنّ معاملات الارتباط دالة عند مستوى ا ....، وذللك يؤكد على

ثبات المقياس.

زمن تطبيق المقياس :

تم تقدير زمن المقياس فى ضوء الملاحظات ومراقبة أداء الأطفال فى ضوء التجربة الاستطلاعية بحساب متوسط الأزمنة الكلية ،من خلال مجموع الأزمنة لكل طفل على عدد

الأطفال وبلغ زمن المقياس مب دقيقة تقريبا .

ع - اعداد برنامج التربية المدنية

تم إعداد البرنامج المقترح القائم على أنشطة التربية المدنية فى ضوء خطوات إعداد

برامج أطفال الروضة وخصائصهم النمائية .

أهدافـ البرنامهج :

ا 1

تتمية بعض مفاهيم الانتماء و المواطنة و تحمل المسئولية الاجتماعية لدى طفـلـل الروضـــة

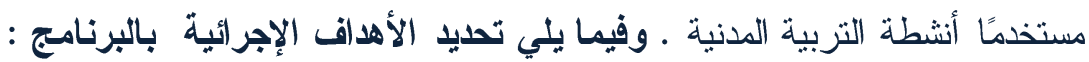




\section{المجلة العلمية لكلية رياض الاطفال - جامعة اسيوط}

بعد الانتهاء من تتفيذ الانشطة يتوقع أن يكون الطفل قادراً على أن :

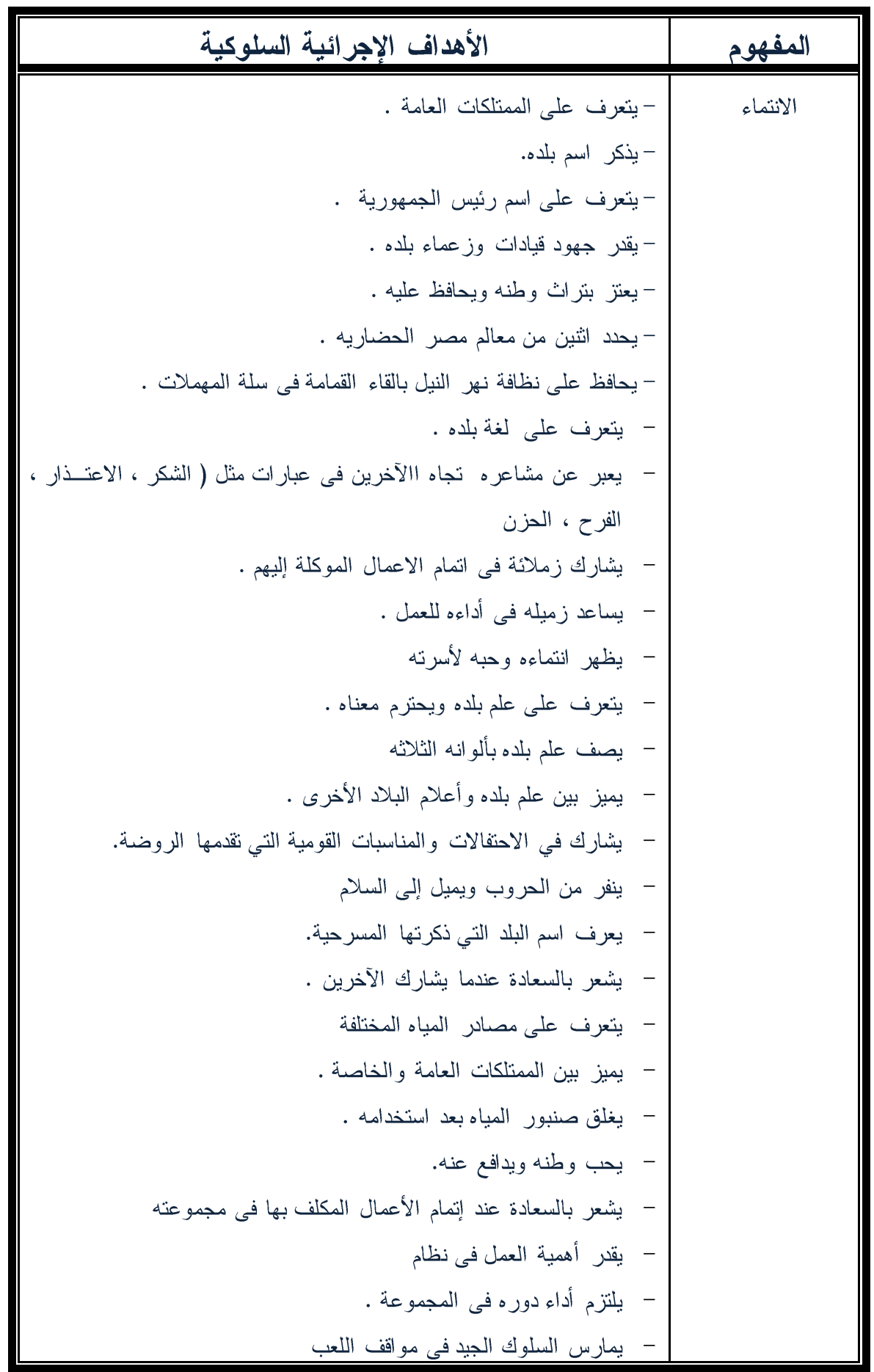


أ.د/ ماجدة هاشـم بخيت

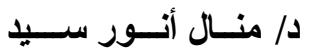

أثر التربية المدنية فى تتمية الاتتماء و المو اطنة

أ/ جمالات غيط عليوه مصطفى

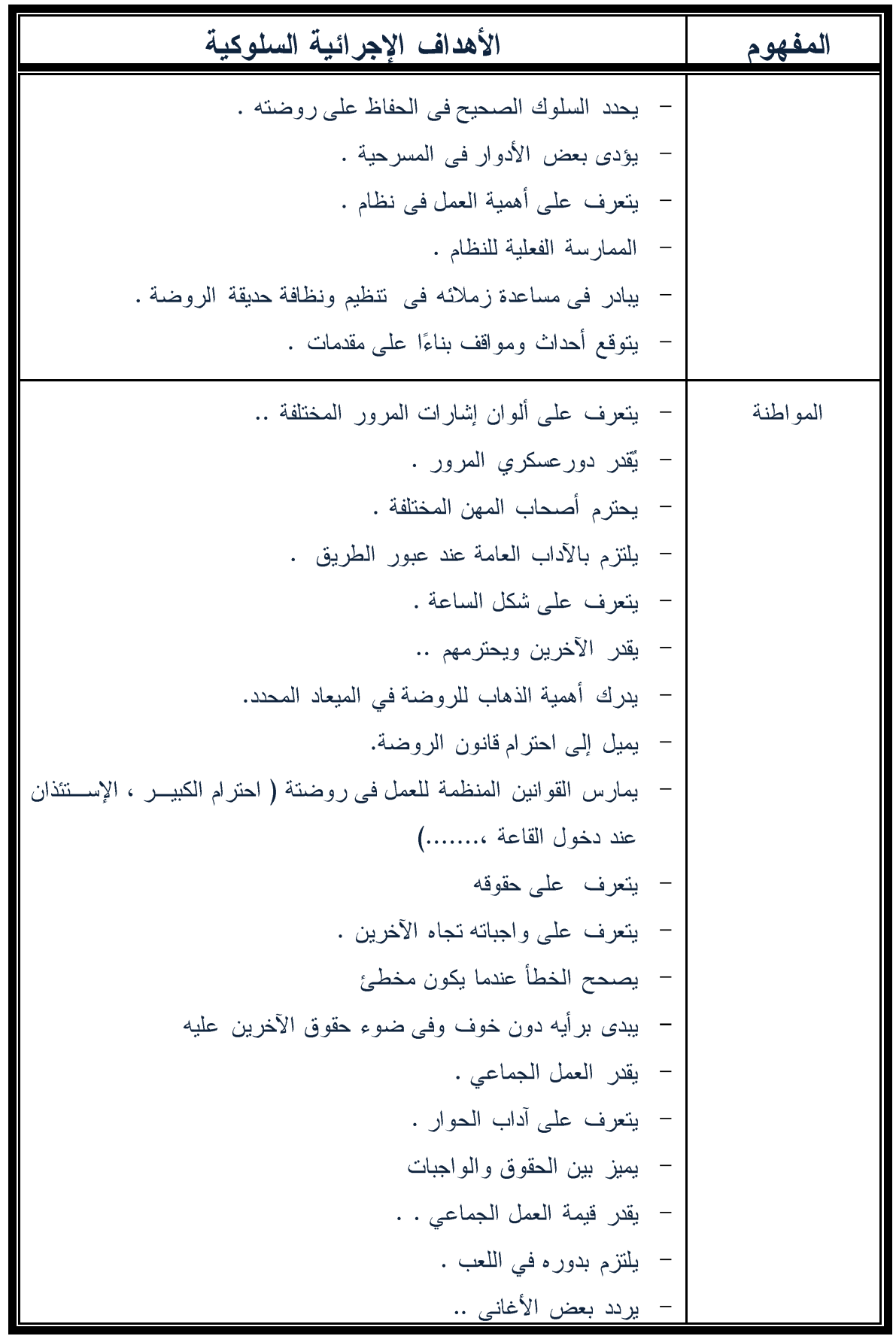

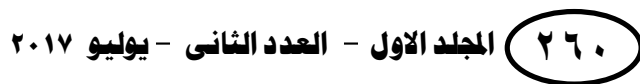


المجلة العلمية لكلية رياض الاطفال - جامعة اسيوط

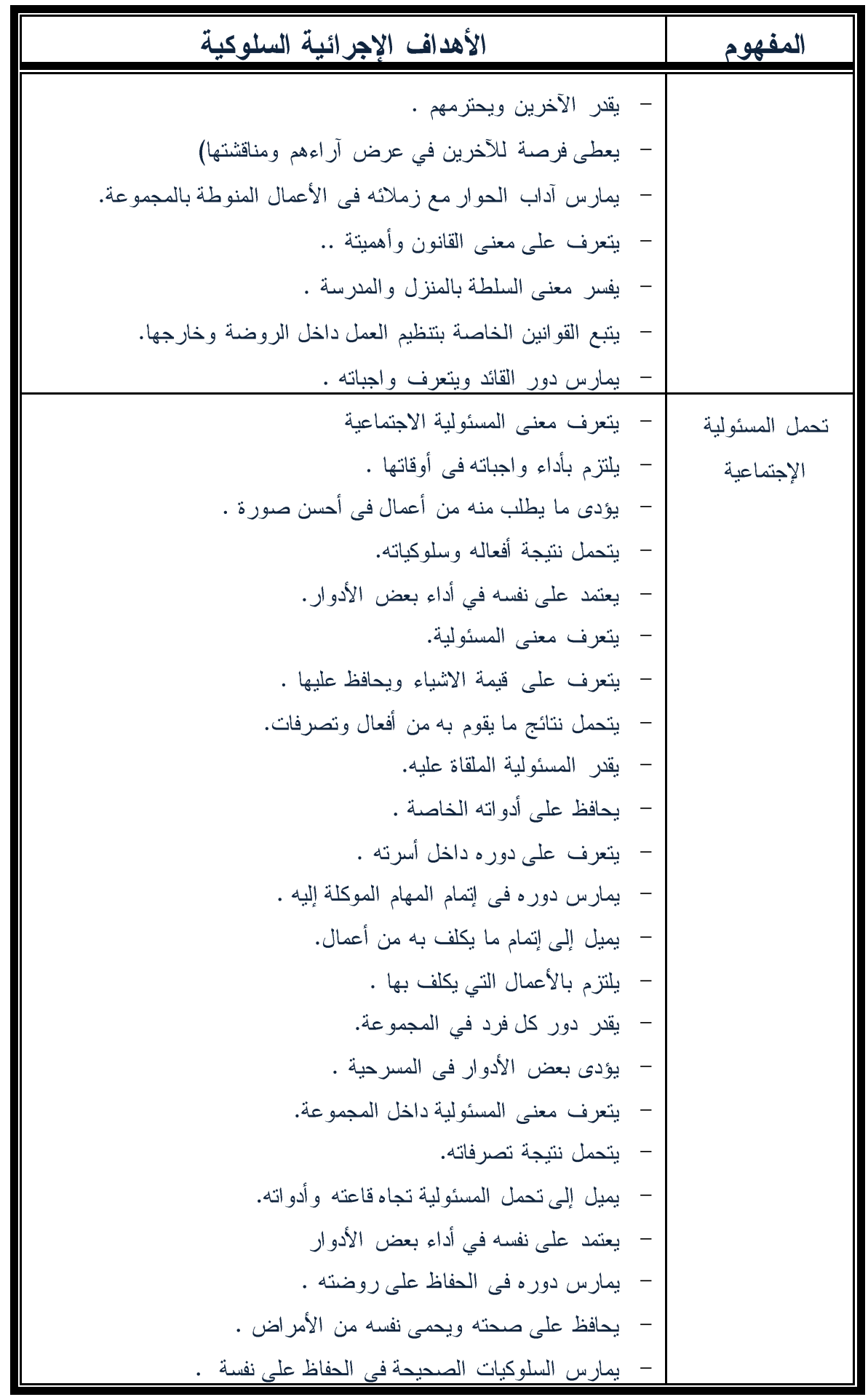


أ.د/ ماجدة هاشـم بخيت

د/ منــال أنــور ســـــ

أثز التربية المدنية فى تتمية الاتتماء والمواطنة

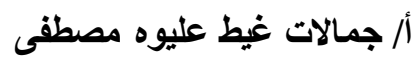

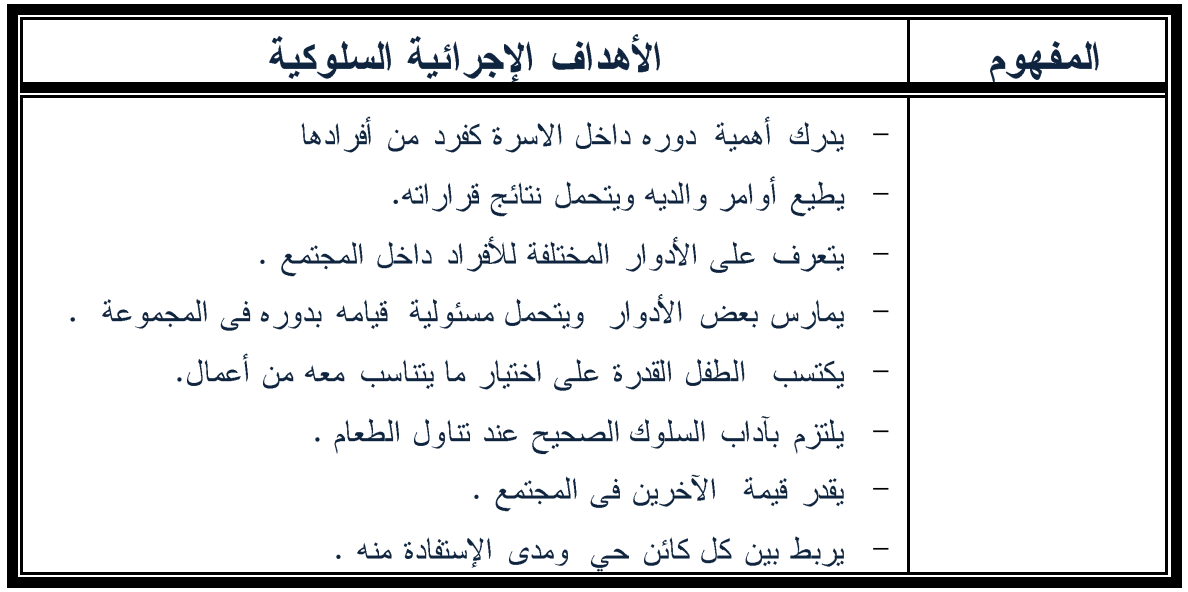

: لمن يقام هذا البرنامج

يستهدف البرنامج المقدم المرحلة العمرية من (ع- 7) سنوات ، والأنشطة التي

ت kg2،kg1 تنتاسب مع المستوى الأول والثاني لطفل الروضة

الأشطة المتضمنة داخل لقاعات البرنامجج :

تعرف الأنشطة بأنها مجموعة من الأداءات و المهام العقلية التي بشترك فيها الأطفال،

و تشتمل على مجموعة من الخبرات التربوية و النماذج المجسمة، وكذلك مجموعة من الأدوات

و الوسائل التي تسهم في تنمية استعدادات الأطفال وقدراتهم العقلية والمعرفية والسلوكية .

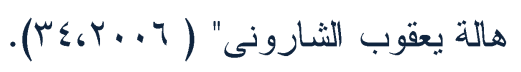

وقد تضمن البرنامج المقترح في هذا البحث مجموعة من الأنشطة والتدريبات التي

تعمل على تتمية مفاهيم الانتماء و المواطنة والمسئولية الاجتماعية، وذلك بأسلوب جذاب

ومشوق وبسيط يعتمد على الممارسة الفعلية من خلال الوسائل و الأداوت التعليمية .

ونتشمل الأنشطة المعدة للبرنامج المقترح على مجالات متعدة من هذه المجالات :

$$
\text { الأثشطة الفنية وتثمثل في : }
$$

- الرسم : رسم حر ورسم مقيد، حيث قام الأطفال برسم بعض الصور ـ وبعد الانتهاء من الرسم تم تجميع الرسومات ومناقثة الباحثة للأطفال في هذه الرسومات واختيار

الرسومات المتميزة وتعليقها في قاعة الروضة في ركن إنتاج الأطفال الخاص بهم . 


\section{المجلة العلمية لكلية رياض الاطفال -جامعة اسيوط}

- التلوين : تلوين حر وتلوين مقيد ، وبعد انتهاء الأطفال من التلوين تتاقش الباحثة

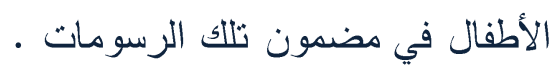
- ممارسة عملية : حيث قامت الباحثة باصطحاب الأطفال إلى حديقة الروضة وقامت فئ بزراعة بعض النباتات معهم والاهتمام بها مع ريّها بالماء، وتتاقتثت معهم في كيفية الحفاظ على الماء لأنه مصدر الحياة . - أنشطة لتمثيل ولعب الأدوار : وذلك لثخصيات القصص و المسرحيات و الأنشطة التي تم عرضها على الأطفال ، حيث يقوم الأطفال بتثثيل أحداث القصة ولعب دولت دور كل شخصية، وتقوم الباحثة باختيار الأطفال المجيدين للتنثيل، وتوزيع الأدوار عليهم وأحيانا يختار لئنيل

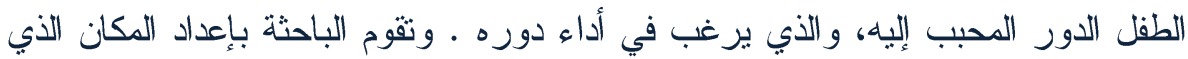

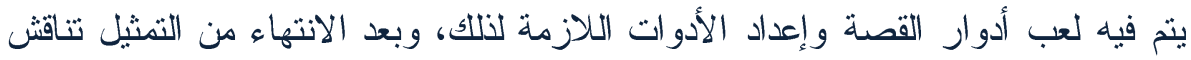

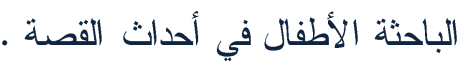
- استخدام الألعاب التعليمية : وهي الأنشطة التي تعمل على زيادة دافعية الطفل ورغبته في التعلم من خلال ممارسته لبعض الألعاب . وقد روبه روعي في هذه الألعاب البساطة و التشويق، وكذلك تفاعل الأطفال مع بعضهم البعض وتنمية قدر اتهم و إمكاناتهم و إكساب لتصن

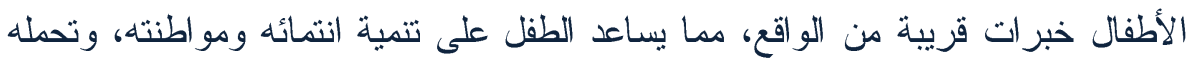

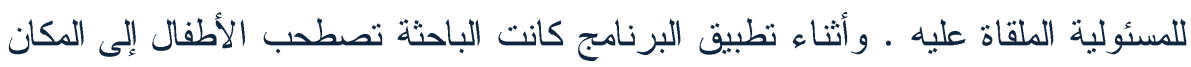

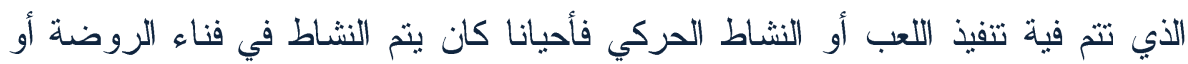
الحديقة أو قاعة الروضة، ويتم تجهيز الككان وما يحتويه من وسائل وأدوات، ثم تشرح

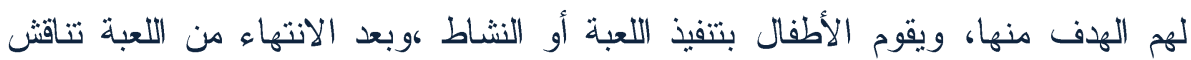

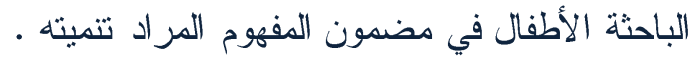
- أنشطة قصصية : حيث اعتد البرنامج الحالي على النشاط القصصي ؛ لأنه من أقوى لـئه الوسائل والأنشطة التي تجذب الطفل بما تحتويه من عناصر النشويق والإثارة، وربطها بالأحداث الجارية ـ فقد اختارت الباحثة شخصيات الحيوانات والطيور، وهي من الأثياء

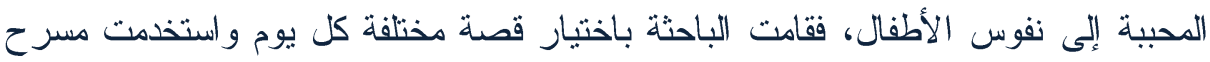

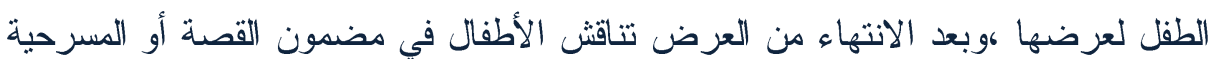
المقدة لهم ، ثم يقوم الأطفال بتأدية الأدوار بأنفسه حتى لأنى ترسخ في أذهانهم . 
أ.د/ ماجدة هاشـم بخيت

د/ منــال أنــور ســـــ

أثر التربية المدنية فى تتمية الاتتماء والمواطنة

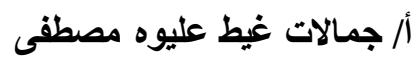

- الأشطة الحركية : وتتمنل في ألعاب بسيطة من جري وققز وإتاحة الحرية للأطفال في ممارستها، وكانت تتم تلك الأنشطة في فناء أوحديقة الروضة فيطة فئه

- الأشطة الموسيقية : والأنشطة تتمنل في بعض الأغاني والأناثيد ،وكنلك بعض التعبيرات

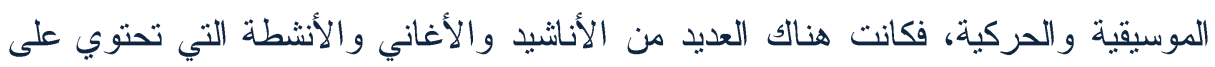
مفاهيم الانتماء و المواطنة والمسئولية الاجتماعية ، وكانت تغنيها الباحثة، فيردد الأطفال

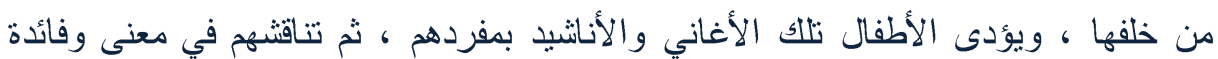

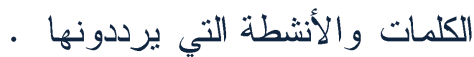

- الأركان التعليمية : هي الأنشطة التي تتمثل في مجموعة من الأركان التي تحتوي على

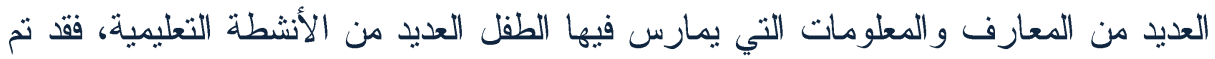

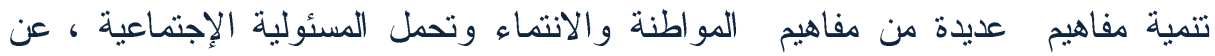

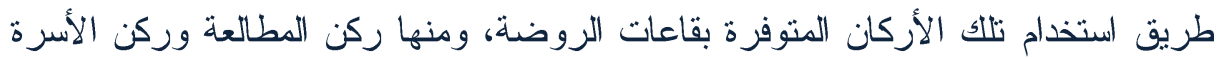

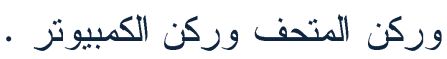
- الوسائل التعليمية : روعي عند تقديم البرنامج الاستعانة بالخبرات المباشرة كلما أمكن ذللك، لما لها من فاعلية ومدى مناسبتها للخصائص العمرية لتلك المرحلة، وكذلك تم مراعاة

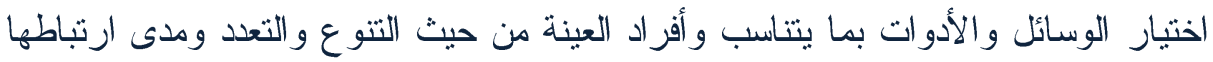

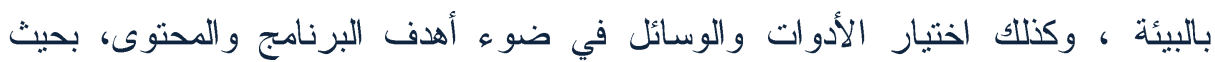
تجذب انتباه الأطفال، وتتكامل طرق تقديم البرنامج لتحقيق أهدافه، وتختلف الوسائل تبعًا

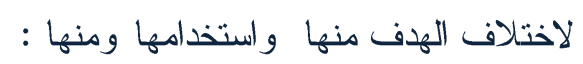
- الوسائل السمعية: مثل النسجيلات الصوتية على الكاسيت للأغاني والأناشيد، وكذلك

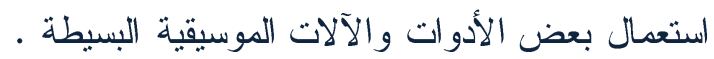

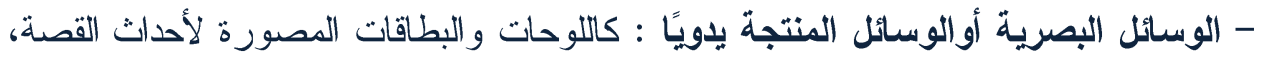
وكنلك السبورة الوبرية والأشطة التي يتم وضع البطاقات عليها.

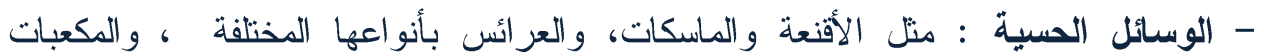
والأوراق و أقلام التلوين والصلصال المستخدم في التشكيل . 


\section{المجلة العلمية لكلية رياض الاطفال -جامعة اسيوط}

- الوسائل البصرية السمعية: منل الكمبيوتز،عن طريق عرض مقطع لفيديو مسجل عليه؛

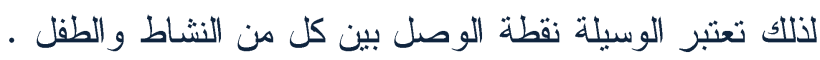
الخطة الزمنية لتنفيذ البرنامج :

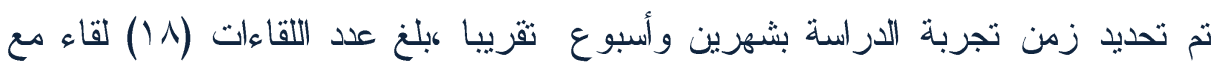

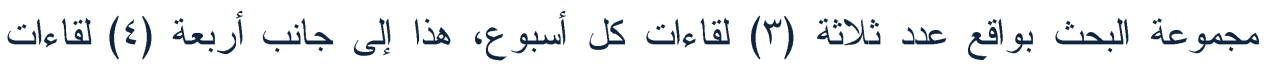

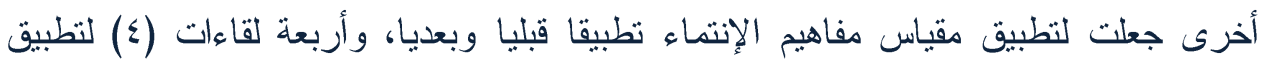

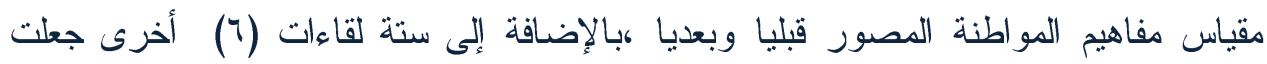

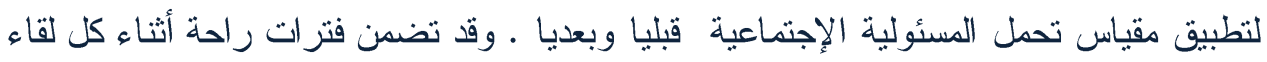

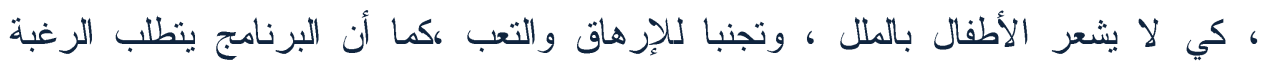

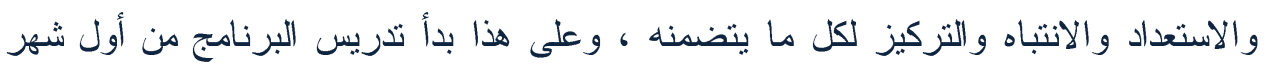

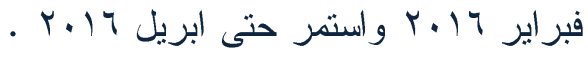

$$
\begin{aligned}
& \text { وتم توزيع اللقاءات كالتالى : }
\end{aligned}
$$

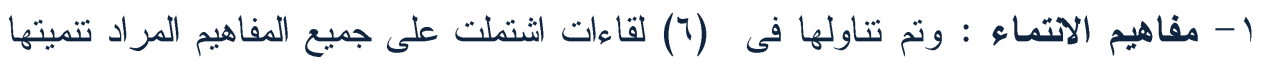

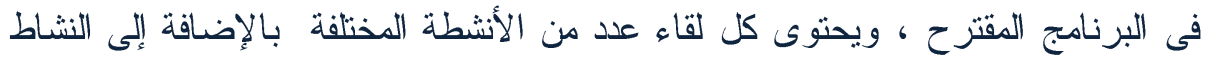

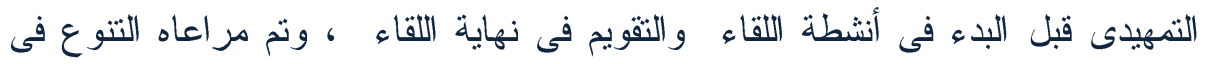

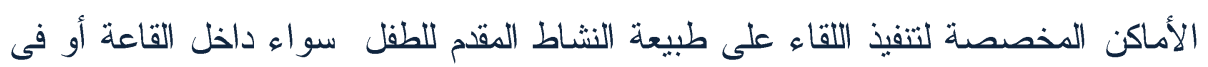

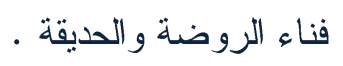

ץ- مفاهيم المواطنة : ونم تتاولها فى(؟) لقاءات الشتملت على جميع المفاهيم المراد تتميتها

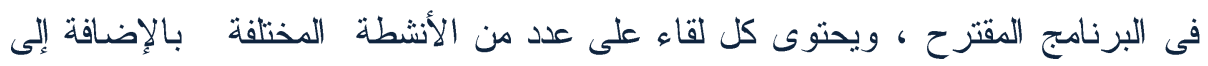

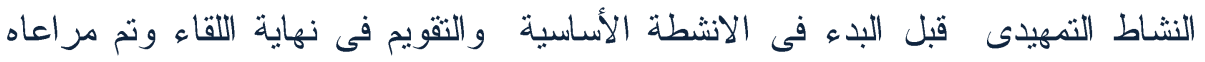

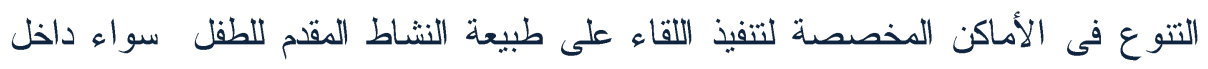
القاعة أو فى فناء الروضة والحنة الحديقة

ץ- تحمل المسئولية الإجتماعية : وتم تتاولها فى(آ) لقاءوات الثتملت على جميع الكفاهيم

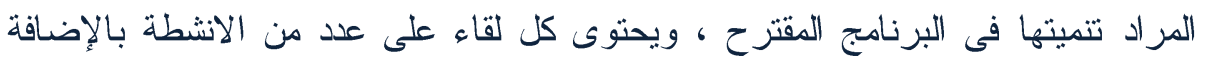

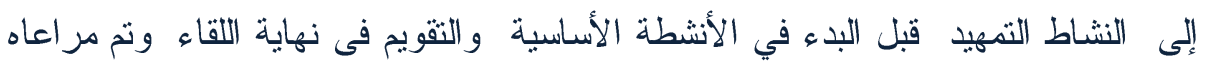

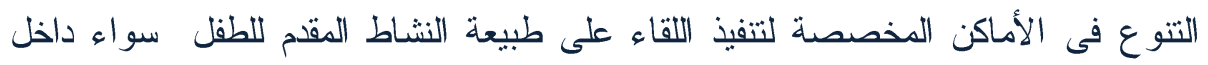
القاعة أو فى فناء الروضة و الأندي العضة. 
أ.د/ ماجدة هاشـم بخيت

د/ منــال أنــور ســـــ

أثر التربية المدنية فى تتمية الاتتماء والمواطنة

أ/ جمالات غيط عليوه مصطفى

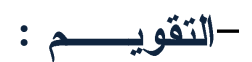

تقويم البرنامـج:

حيث تم تقويم البرنامج على ثلاث مراحل :

أ ) التقويم المبائي: ويتم استخدام هذا التقويم في كل نشاط من أنشطة البرنامج قبل البدء في تطبيق النشاط للتعرف على مدخلات الأطفال، كما يتم تطبيق مقياس مفاهيم الانتماء

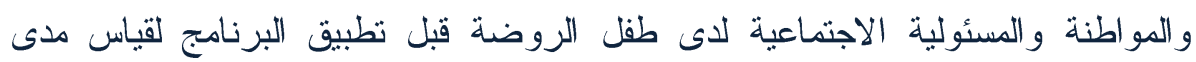

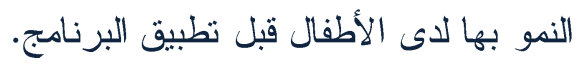

ب) التقويم المرحلي: تمثل فى الأسئلة الثنفهية والصور و الرسوم والنماذج ومختلف الوسائل

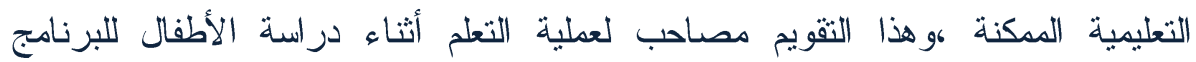
المقترح، بمعنى انه يسير جنبا إلى جنب مع عملية التعلم ،وذللك لتصحيح الأخطاء وتعديل مسار التعلم إلا بأول بما يتناسب مع الأهداف التى يسعى البر انامج لتحقيقها .

ج) التقويم التهائي: لدّا كان الهدف من البرنامج هو تنمية بعض مفاهيم الانتماء و المواطنة و تحمل المسئولية الاجتماعية لاى طفل الروضة؛ فإنه تم إعادة تطبيق مقياس مفاهيم

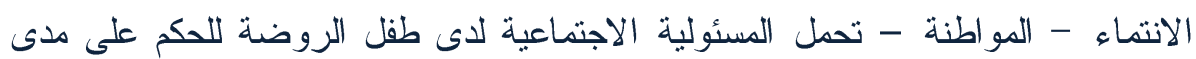

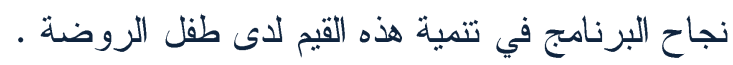
تحكيم البرنامج :

بعد الانتهاء من إعداد البرنامج في صورته الأولية تم عرض البرنامج على مجموعة من المحكمين (1) محكمًا من المتخصصين فى المناهج وطرق التدريس بكلية التربية جامعة أسيوط وكلية التزبية جامعة سوهاج، ومتخصصين فى تزبية الطفل بكلية التربية جامعة

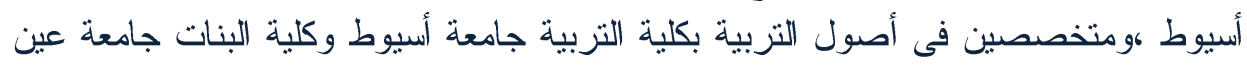
شمس وكلية التربية جامعة عين شمس ،ومتخصصين فى علم النفس التربوى بكلية التزبية جامعة المنيا ومتخصصين فى الصحة النفسية بكلية الترية جامعة أسيوط ومعلمه وموجهة فية

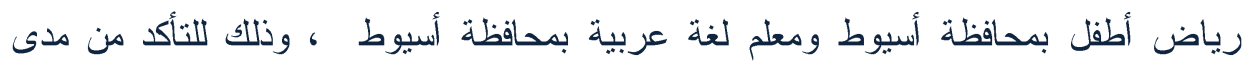
صلاحيته قبل تطبيقه على عينة الدراسة وقد اتضح من خلال الاطلاع على آراء السادة

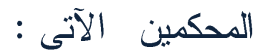

الإجماع على صلاحية البرنامج للتطبيق على عينة الدراسة بعد إجراء بعض التعديلات

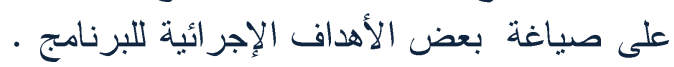

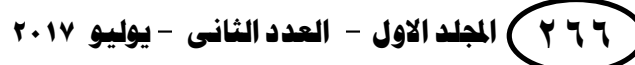


ثانياً : الإجراعات التجريبية للار اسة الحالية :

عينة الار اسة : الاجة

تم اختيار عينة الدراسة والتى تكونت من (• آ) طفلاً وطفلة ، حيث وقع الاختيار بطريقة

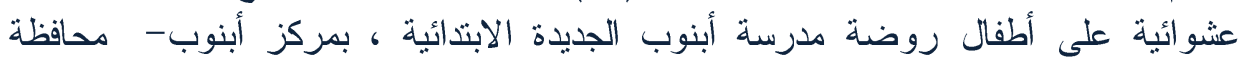

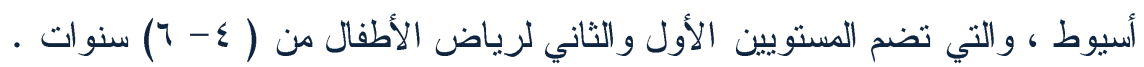

\section{التصميم التجريبي للار اسة :}

استخدت الدراسة الحالية المنهج شبه التجريبي ذو المجموعتين ،وتم توزيع عينة الدراسة

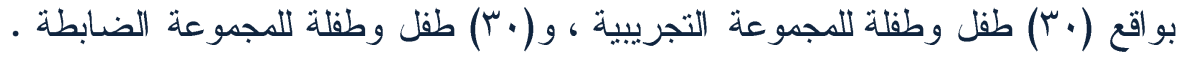
متغيرات الاراسة : اشتملت الداراسة الحالية على المتغيرات الآتية : أ- المتغير التجريبي (المستقل) :

المتغير التجريبي فى هذه الدراسة هو التربية المدنية واستخدامها فى تتمية مفاهيم المواطنة والانتماء وتحمل الدسئولية الاجتماعية ، حيث لهيثة تم استخدام التربية المدنية بتفعيل

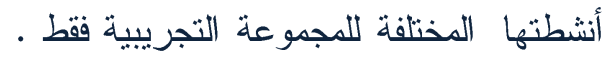

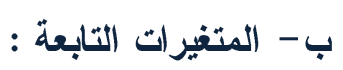

بعض مفاهيم الانتماء (حب الوطن ، المشاركة ، النظام ، مساعدة الآخرين) ·

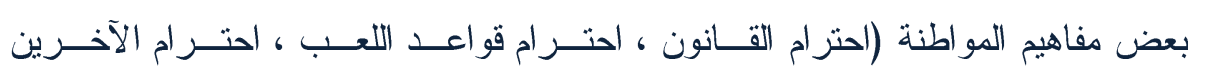

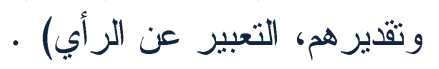

• مفاهيم المسئولية الإجتماعيه (آداب السلوك ، الاعتماد على النفس ، المشاركة ) .

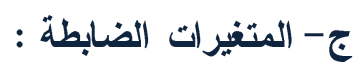

• العمر الزمنى : روعى عند اختيار مجموعة الدراسة تقارب العمر الزمنى للأطفال ،

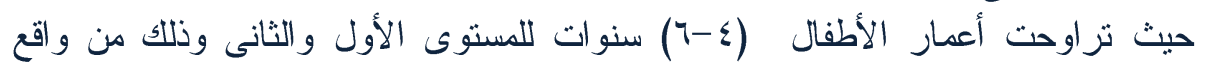

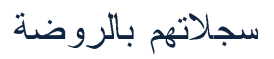

المستوى الاجتماعى والثقافى : تمتل أطفال مجموعة الدراسة منطقة جغرافية وبيئية

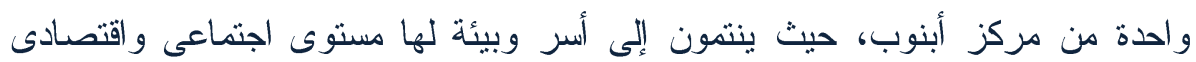

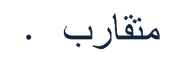

• الظروف الطبيعية أوالفيزيقيه : روعى أن يتم تطبيق أدوات الدراسة لمجموعتى الدراسة فى نفس الظروف الفيزيقية من حرارة وضوء أونهية وتهوية ورطوبة. 
أ.د/ ماجدة هاشـم بخيت

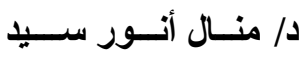

أثز التربية المدنية فى تتمية الاتتماء والمواطنة

أ/ جمالات غيط عليوه مصطقى مصل

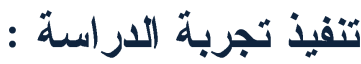

\section{التطبيق القبلي لأدوات الاراسة :}

تم تطبيق مقياس مفاهيم الانتماء المصور ( تطبيق قبلى ) علـى عينتـى الدراسة للتحقق من عدم وجود فروق ذات دالة إحصائية بين متوسطي درجات المجموعة

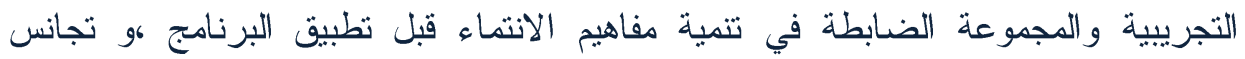
عينتي الدراسة ، تم استخدام اختبار ت للعينات البارامترية للأزواج المستقلة من خلاءلئل البرنامج الإحصائي Spss ، وجدول (V) ) يوضح ذلت جدول (v)

الفروق بين المجموعتين الضابطة والتجريبية على مقياس مفاهيم الآتماء المصور قبل التعرض للبرنامج

\begin{tabular}{|c|c|c|c|c|c|c|}
\hline الالامة & قيمة T & الالتحر اف المعياري & المتوسط & العدد & المجموعة & الأبعاد \\
\hline \multirow{2}{*}{ غبر دالة عند } & \multirow[t]{2}{*}{. .71} & $1 . r .10 r$ & Y.YYTV & $r$. & ضابطة & \multirow[t]{2}{*}{ وطن } \\
\hline & & 1.01 & r.or.. & r. & تجريبية & \\
\hline \multirow[t]{2}{*}{ غير دالة عند } & \multirow[t]{2}{*}{. .01} & $1.11 \ldots$ & r.77.. & $r$. & ضابطة & \multirow[t]{2}{*}{ مشاركة } \\
\hline & & 1.71 & r.Ao & r. & تجريبية & \\
\hline \multirow[t]{2}{*}{ غبر دالة عند } & \multirow[t]{2}{*}{. .01} & $1 . \wedge \varepsilon \varepsilon \wedge \varepsilon$ & $1.9 \ldots$ & $r$. & ضنابطة & \multirow[t]{2}{*}{ نظام } \\
\hline & & 1.09 & Y.197V & r. & تجريبية & \\
\hline \multirow[t]{2}{*}{ غير دالة عند } & \multirow[t]{2}{*}{$\because r \mid r$} & $1 . \wedge \mu V \cdot \varepsilon$ & משrא. & r. & ضنابطة & \multirow[t]{2}{*}{ مساعدة } \\
\hline & & 1.20 & משrAT. & r. & تجريبية & \\
\hline \multirow[t]{2}{*}{ غير دالة عند } & \multirow[t]{2}{*}{1.14} & $4.7+491$ & $1.00 \ldots$ & r. & ضابطة & \multirow{2}{*}{ مقياس } \\
\hline & & I.rEITI & 11.1778 & r. & تجريبية & \\
\hline
\end{tabular}

يتضح من جدول (V) عدم وجود فروق ذات دالة إحصــائية بــين متوســطات درجــات المجموعتين التجريبية و الضابطة وذلك عند مستوى دلالة ( ( . . . ) في التطبيق القبلـي للأبعـاد

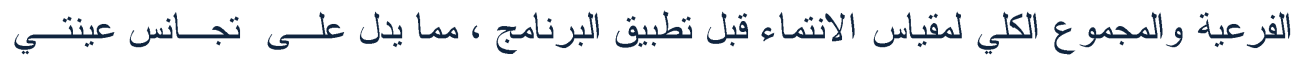

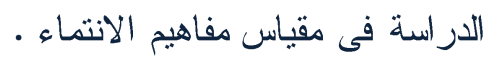




\section{المجلة العلمية لكلية رياض الاطفال -جامعة اسيوط}

ثانياً التكافؤ بين المجموعتين الضابطة والتجريبية في مقياس مفاهيم المواطنة:

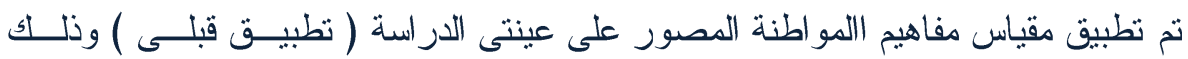

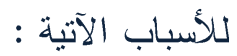

للتحقق من عدم وجود فروق ذات دالة إحصائية بين متوسطي درجات المجموعة التجريبيــة

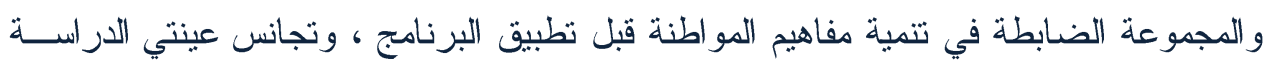

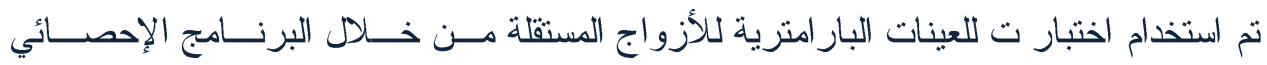
Spss، وجدول (^) يوضح نلك.

جلول (^)

الفروق بين المجموعتين الضابطة والتجريبية على مقياس

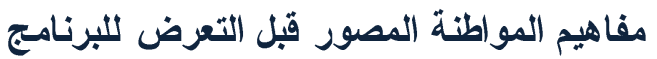

\begin{tabular}{|c|c|c|c|c|c|c|}
\hline الدلامة & قيمة T & الالنحر اف المعياري & المثتوسط & العدد & المجموعة & الأبعاد \\
\hline \multirow{2}{*}{ غير دالة } & \multirow[t]{2}{*}{.$\wedge 0 \mathrm{~V}$} & $1 . V \leqslant 104$ & Y.747V & r. & ضابطة & \multirow[t]{2}{*}{ قانون } \\
\hline & & $1 . \leqslant 97 \vee \leqslant$ & זrז. ..r & r. & تجريبية & \\
\hline \multirow{2}{*}{ غنير دالة } & \multirow[t]{2}{*}{$1 . r 4$} & 1.10700 & Y.VYTV & r. & ضابطة & \multirow[t]{2}{*}{ قو اعد } \\
\hline & & $1 . \leqslant 0 \leqslant 71$ & מזrז.r & r. & تجريبية & \\
\hline \multirow{2}{*}{ غنبر دالة } & \multirow[t]{2}{*}{.9.} & $1.0 \wedge \wedge \vee 0$ & Y.乏... & r. & ضابطة & \multirow[t]{2}{*}{ أر اء } \\
\hline & & $1.0 .11 \mathrm{~s}$ & Y.VYTV & r. & تجريبية & \\
\hline \multirow{2}{*}{ غنبر دالة } & \multirow[t]{2}{*}{$1 . \varepsilon Y$} & I.Tr. & אسזA.1 & r. & ضابطة & \multirow[t]{2}{*}{ رأي } \\
\hline & &. .99 & זrسז.ץ & r. & تجربيية & \\
\hline \multirow{2}{*}{ غند دالة } & \multirow[t]{2}{*}{.97} & $\varepsilon .01 \mathrm{H} \cdot \mathrm{V}$ & $1 . .7478$ & r. & ضابطة & \multirow{2}{*}{ مقباس المو اطنة } \\
\hline & & T. $\leqslant \leqslant \wedge q \vee$ & 11. & r. & تجريبية & \\
\hline
\end{tabular}

يتضح من جدول (^) عدم وجود فروق ذات دالة إحصائية بين متوسـطات درجـات

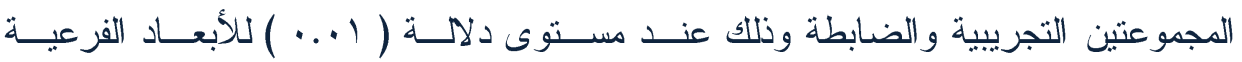

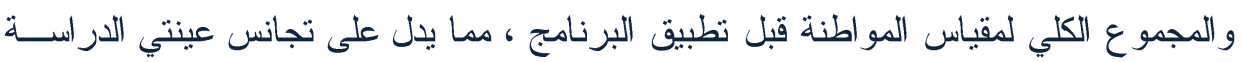

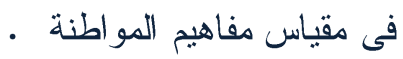


أ.د/ ماجدة هاشـم بخيت

د/ منــال أنــور ســـــ

أثز التربية المدنية فى تتمية الاتتماء والمواطنة

أ/ جمالات غيط عليوه مصطقى مدرل

ثأثثاً التكافؤ بين المجموعتين الضابطة والتجريبيــة فــي مقيــاس تحمـلـل

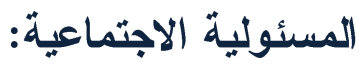

تم تطبيق مقياس تحمل المسئولية الإجتماعية المصور على عينتى الدراسة( تطبيق قبالـى )

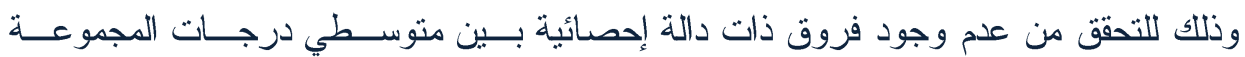

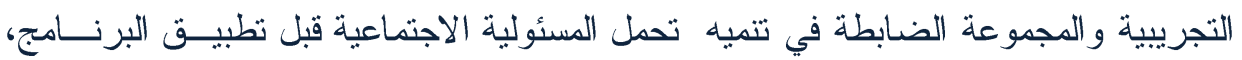

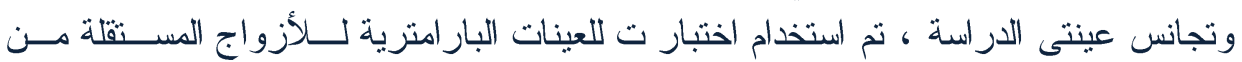

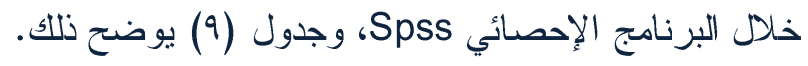

جدول (9) جون (9)

الفروق بين المجموعتين الضابطة والتجريبية على مقياس

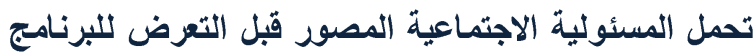

\begin{tabular}{|c|c|c|c|c|c|c|}
\hline الالالة & قيمة T T & الآحراف المعياري & المثتوسط الحسبي & العدد & المجمو عة & الأبعاد \\
\hline \multirow{2}{*}{ غير دالة عند } & \multirow[t]{2}{*}{$\cdots \varepsilon \cdot 1$} & Y.AY $\leqslant 0 Y$ & A.\&लr & $r$. & ضابطة & \multirow[t]{2}{*}{ بعد المشاركة } \\
\hline & & I.rIYq4 & A.TTTV & r. & تجريبية & \\
\hline \multirow{2}{*}{ غير دالة عند } & \multirow[t]{2}{*}{$. r \leqslant r$} & Y.OSOYY & $V . .47 V$ & $r$. & ضابطة & \multirow[t]{2}{*}{ بعد السلوك } \\
\hline & & T.TYYYY & ד.גזr & $r$. & تجريبية & \\
\hline \multirow{2}{*}{ غير دالة عند } & \multirow[t]{2}{*}{1.9} & r.1777ะ & V.A... & $r \cdot$ & ضابطة & \multirow[t]{2}{*}{ ملابس } \\
\hline & & $1 \ldots r \leq \leqslant$ & $7.7 \ldots$ & $r \cdot$ & تجريبية & \\
\hline \multirow{2}{*}{ غير دالة عند } & \multirow[t]{2}{*}{1.19} & Y.A 1.09 & $9 \ldots \ldots$ & $r$. & ضابطة & \multirow[t]{2}{*}{ نظام } \\
\hline & & Y.. $\leqslant 0 V \leqslant$ & V.VTYV & $r$. & تجرييية & \\
\hline \multirow{2}{*}{ غير دالة عند } & \multirow[t]{2}{*}{$\therefore 199$} & $1.9 \leqslant-\leqslant 9$ & $7.7 \ldots$ & $r$. & ضابطة & \multirow[t]{2}{*}{ طعام } \\
\hline & & r..IVIV & v..... & $r$. & تجريبية & \\
\hline \multirow{2}{*}{ غير دالة عند } & \multirow[t]{2}{*}{$. .1 \leqslant r$} & r.VYO9Y & 1..1rr & $r$. & ضابطة & \multirow[t]{2}{*}{ أمن } \\
\hline & &.$\wedge \Lambda$ & $1+. r 11$ & $r$. & تجريبية & \\
\hline \multirow{2}{*}{ غير دالة عند } & \multirow[t]{2}{*}{$\ldots \leqslant r$} & $r . V \leq \leqslant \wedge \Lambda$ & $9.9 \ldots$ & $r$. & ضابطة & \multirow[t]{2}{*}{ نظافة } \\
\hline & & 1.ATrKA & 9.ภT4V & $r$. & تجريبية & \\
\hline \multirow{2}{*}{ غير دالة عند } & \multirow[t]{2}{*}{$1 . .9$} & $A . V \leq \Lambda) \leq$ & ST. & $r$. & ضابطة & \multirow[t]{2}{*}{ بعد الاعتماد } \\
\hline & & $\leq .5719 \mathrm{~V}$ & (1. & $r$. & تجريبية & \\
\hline \multirow{2}{*}{ غير دالة عند } & \multirow[t]{2}{*}{. nor } & $11 . v \cdot r \cdot r$ & ON.9rer & $r$. & ضابطة & \multirow[t]{2}{*}{ مقياس الدسئولية } \\
\hline & & s.V।19r & 07.9rr & $r$. & تجريبية & \\
\hline
\end{tabular}

يتضح من جدول (9) عدم وجود فروق ذات دالــة إحصــائية بــين متوســطات درجــات المجموعتين التجريبية و الضابطة وذلك عند مستوى دلالة (1 +. +) في التطبيق القبلـي للأبعـاد الفرعية و المجموع الكلي لمقياس تحمل المسئولية الاجتماعية ، ، مما بدل على تجانس عينتـي الدراسة فى مقياس تحمل المسئولية الإجتماعية . 
نتائج الار اسة :

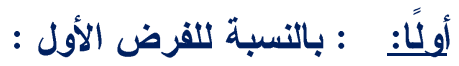

للنحقق من صحة الفرض الأول الذى ينص على " توجد فروق ذات دالة إحصائية

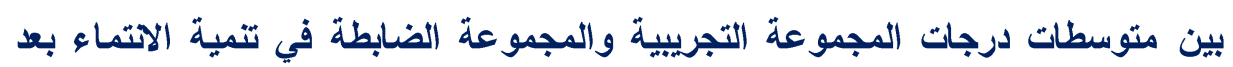

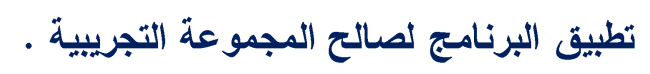

تمت المقارنة بين نتائج مجموعة الدراسة في التطبيق القبلي و التطبيق البعدي لكقياس

الانتماء.

\section{جدول (1.)}

يوضح المتوسط الحسابى والآحر اف المعيارى وقيمة (ت) (ت)

فى التطبيق القبلى والبعدى فى مقياس الآتماء

\begin{tabular}{|c|c|c|c|c|c|c|}
\hline الالالة & قيمة T & الالندر اف المياري & المتوسط الحسابي & العدد & المجموعة & الأبعاد \\
\hline \multirow[t]{2}{*}{ دالة عند ا +.. } & \multirow[t]{2}{*}{$|Y|}$. & $1 . r \cdot 10 r$ & Y.YצY & r. & ضابطة & \multirow[t]{2}{*}{ و طن } \\
\hline & &. .01 & 0. YTYV & r. & تجريبية & \\
\hline \multirow[t]{2}{*}{ دالة عند +.. } & \multirow[t]{2}{*}{ Ir.Ir } & $1.11 \ldots$ & r.77.. & r. & ضابطة & \multirow[t]{2}{*}{ مشاركة } \\
\hline & & .71 & 0.70 & r. & تجريبية & \\
\hline \multirow[t]{2}{*}{ دالة عند +.. } & \multirow[t]{2}{*}{$9 . \cdot 1$} & $1 . \wedge \varepsilon \varepsilon \wedge \varepsilon$ & $1.9 \ldots$ & r. & ضابطة & \multirow[t]{2}{*}{ نظام } \\
\hline & &. .09 & $0.177 \mathrm{~V}$ & r. & تجريبية & \\
\hline \multirow[t]{2}{*}{ دالة عند +... } & \multirow[t]{2}{*}{$\wedge . \leqslant 1$} & I.ATV. E & אسזV. & r. & ضابطة & \multirow[t]{2}{*}{ مساعدة } \\
\hline & &. Vo & אسזA. & r. & تجريبية & \\
\hline \multirow[t]{2}{*}{ دالة عند +.. } & \multirow[t]{2}{*}{$1 . .19$} & $0.7+491$ & $1.00 \ldots$ & r. & ضابطة & \multirow{2}{*}{ مقياس } \\
\hline & & $|. r \leq| r \mid$ & YY.ITTV & r. & تجريبية & \\
\hline
\end{tabular}

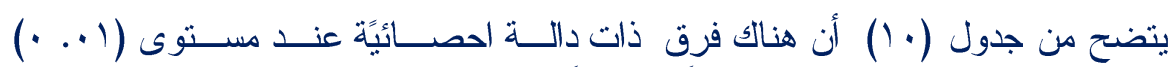

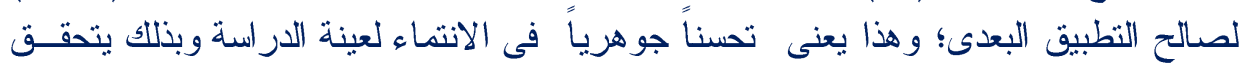

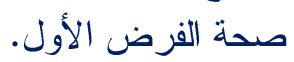

تفسير النتائج المتعلقة بالفرض الاول الأول :

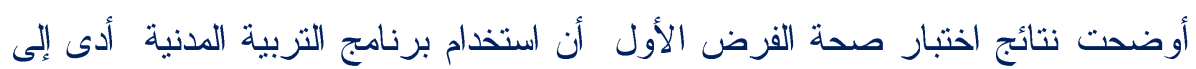

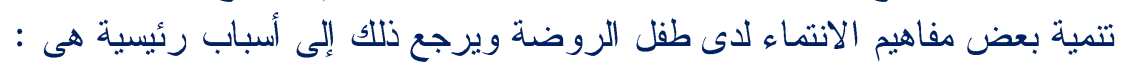


أ.د/ ماجدة هاشـم بخيت

د/ منــال أنــور ســـــ

أثر التربية المدنية فى تتمية الاتتماء والمواطنة

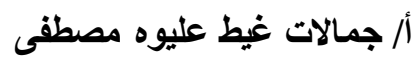

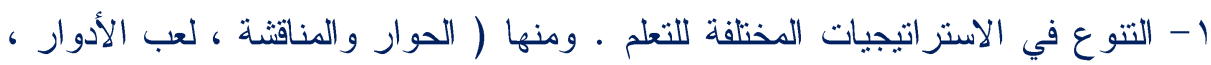

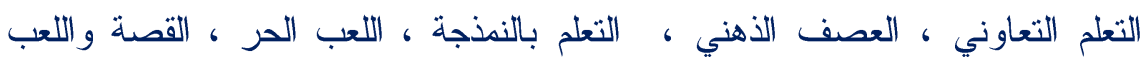

(التمثيلى )

r- اعتماد البرنامج على التثريب العملي والخبرة المباشرة للأطفال و التعاون أثناء اللعب

مع الأقران و المعلمة، ومشاركتهم الأنشطة المختلفة والاحتفال معهم بالمناسبات المختلفة، والحرص على التعبير عن حب الوطن والاعثزاز باللغة و المحافظة على ولى الآثار والممنلكات العامة والخاصة عن طريق تقديم مسرحيات باستخدام مسرح

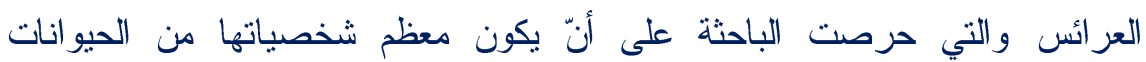
و الطيور؛ لأن الطفل يهيم بخياله، ويثير تقكيره ،ومحبب إلى نفسه تلك الثخصيات الخيالية، منل مسرحية ( رحلة فيها العجب)، والتي منلت أحداثها شخصية كروان وكروانة، وتتحدث عن أهمية المحافظة على نهر النيل وأهميته في حياتنا، كما عرض وحنة

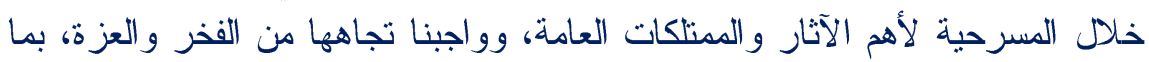

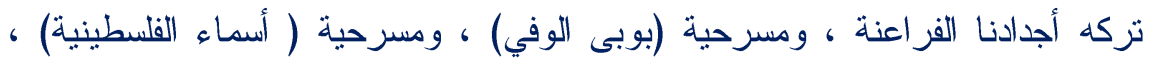

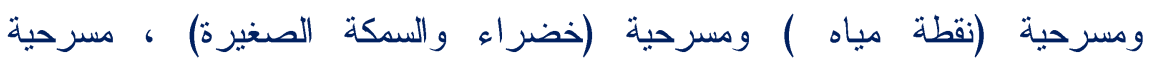
(سامي الكسول)

س- ساعدت الأنشطة والأدوات المستخدمة على فهم وتتفيذ تلك الأنشطة مثل الأنشطة الفنية و التى تعدد على ممارسة الأطفال وحبهم وشغفهم بالرسم و التلوين. ع - ساعد استخدام الأنشطة الحركية وتتفيذ هذه الأنشطة مع الأطفال إلى ت تنمية الشعور

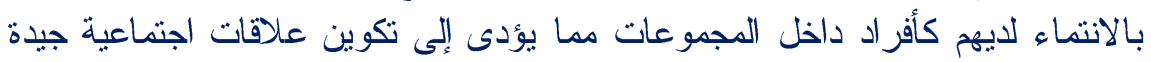

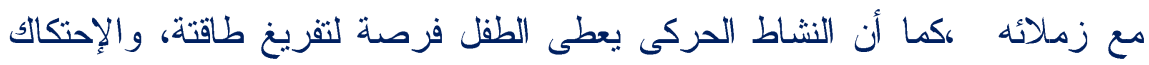
بزملائه فى جو غير نقليدى يتسم بالحرية ونتفق هذه النتيجة مع الدراسات السابقة التالية:

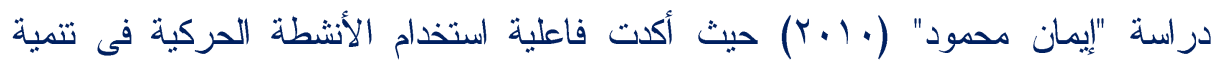
بعض عناصر الانتماء، دراسة (2010) "Jane Thomas" والتى أكت على أهمية الأنشطة

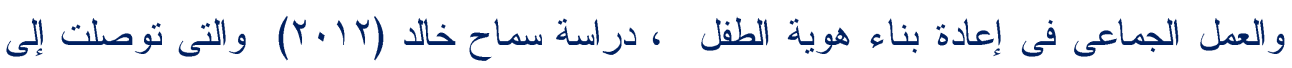
أهمية العلاقات الاجتماعية فى تتمية الانتماء فكلما زادت العلاقات زاد شعور الطفل بالانتماء إلى

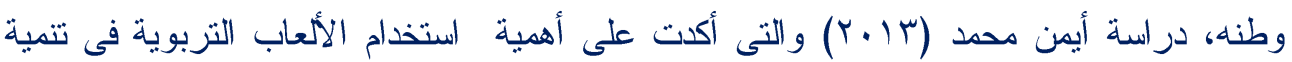
الانتماء لدى طفل الروضة . 


\section{المجلة العلمية لكلية رياض الاطفال - جامعة اسيوط}

0 - استخدام الأنشطة الموسيقية فى أنشطة البرنامج لتنمية الانتماء لاى الطفل .

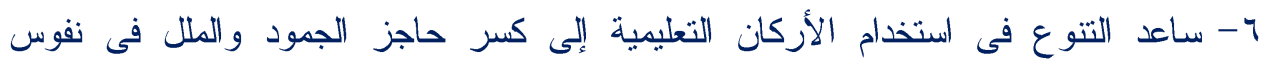

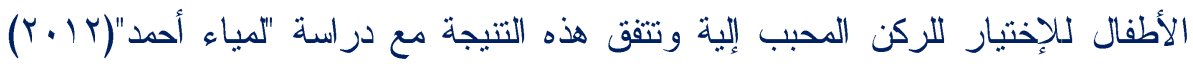

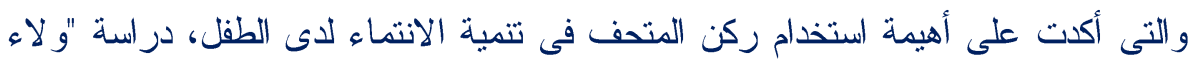

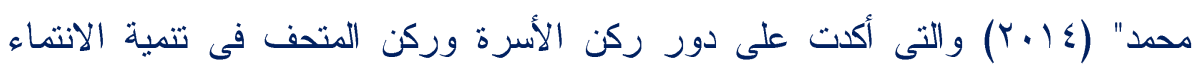
وعلاج بعض المشكلات السلوكية لدى الأطفال .

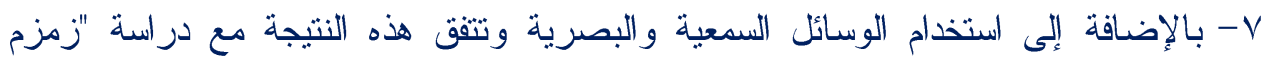

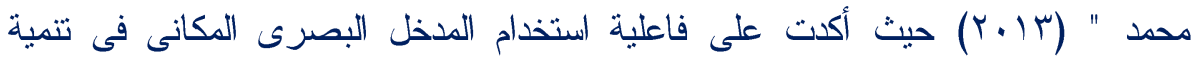

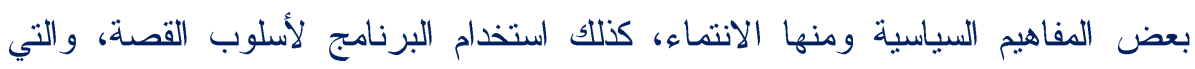

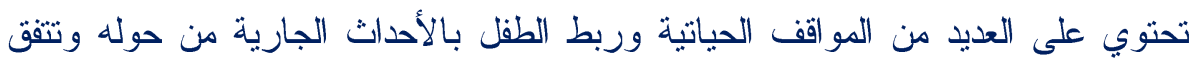

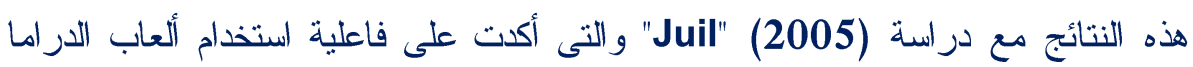

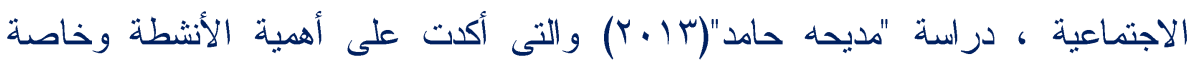

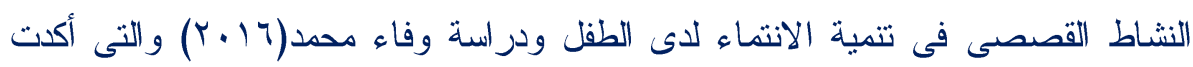
على أهية القصة باستخدام مسرح العرائس لأنه من أحب الفنون إلى الأطفال التي تثثير

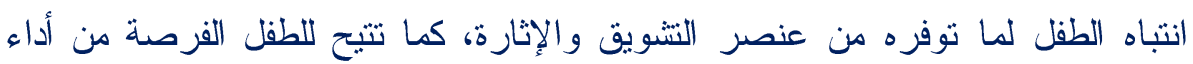

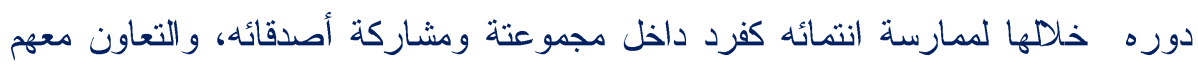
في نظام.

1- وكذلك استخدام الأنشطة المختلفة والتي تعتى بشكل مبانشر على ممارسة الطفل لدوره بحرية دون تقييد، مع التعبير عن رغباته من خلال التتوع فى استخدام تلك الأنشطة،

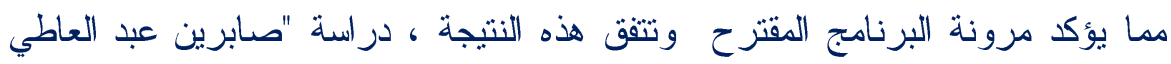

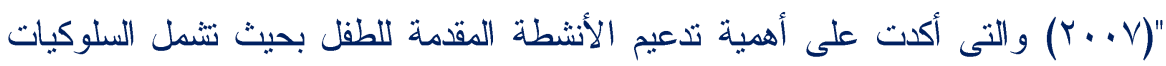
و المعاملات الحميدة المرغوب فيها مثل النظافة ، و النظام ، و التعاون ، دراسة النئه "ماجدة

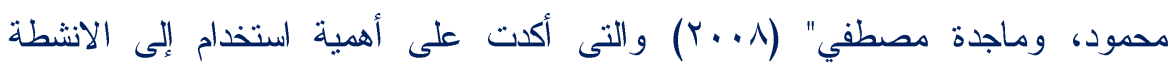

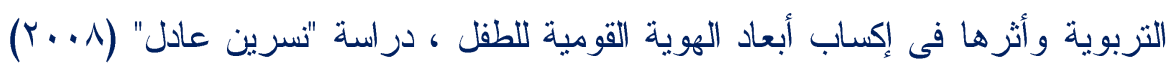

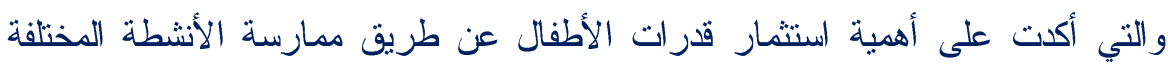

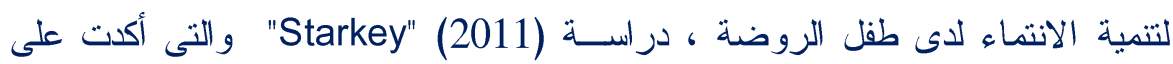


أ.د/ ماجدة هاشـم بخيت

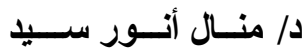

أثر التربية المدنية فى تتمية الاتتماء و المواطنة

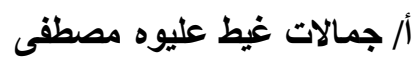

أهية تتمية الانتماء لدى الطفل للتقليل من بعض المظاهر السلبية والتي تؤثر فى تشكيل

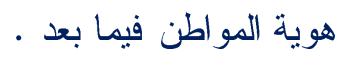

كما ساعد عنصر التقويم بعد كل نشاط على إكساب وفهم معنى الانتماء وكيفية تحقيقه بطرق مباشرة وغير مباشرة، من خلال الممارسة العملية، والتي تعتبر أساسا تقوم عليه التربية المدنية، وهي إعداد الطفل للحياة أيَّا كان موقعه داخل المجموعات المختلفة . حجم الأثز ونسبة الكسب المعدل لبلاك: لتحديد أثر فاعلية التربية المدنية في تتمية الانتماء لدى طفل الروضة ، ثم حساب نسبة الكسب المعدل لبلاك "Blake".

ولحساب نسبة الكسب المعدل لـ بلاك ( Blake ):

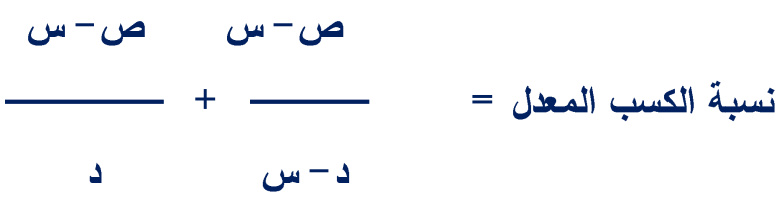

حيث : " ص" متوسط الدرجة في القياس البعدي ،" س " : متوسط الدرجة في القياس القبلي، د • النهاية العظمى للاختبار :

حيث ثتراوح نسبة الكسب المعدلة بين (صفر ، ب) ويقترح ( Black) أنه إذا بلغت هذه النسبة r.ا فإنه يمكن اعتبار البرنامج ذي فاعلية حيث : ص = متوسط درجات الأطفال في القياس البعدي. س = متوسط درجات الأطفال في القياس القبلي د = النهاية العظمى للمقياس . 


\section{المجلة العلمية لكلية رياض الاطفال - جامعة اسيوط}

جدول (11)

المتوسط الحسابي والاحر اف المعياري وقيمة (ت)

وحجم الأثر ومعل بلاك لمقياس تتمية الاتماء

\begin{tabular}{|c|c|c|c|c|c|c|c|c|}
\hline الالالة & بلاد & مربع & قيمة T & الالمعراف & العسابي & العدد & التطبيق & الأبعاد \\
\hline \multirow[t]{2}{*}{ كبير } & \multirow[t]{2}{*}{$1 . r 1$} & \multirow{2}{*}{ r } & \multirow[t]{2}{*}{ r... } & $1 . r \cdot 10 r$ & T.YYTV & r. & قبلى & \multirow[t]{2}{*}{ وطن } \\
\hline & & & & .01 & O.rMTV & r. & بعدب & \\
\hline \multirow[t]{2}{*}{ كبير } & \multirow[t]{2}{*}{$1 . r 9$} & \multirow{2}{*}{.$\wedge \varepsilon$} & \multirow[t]{2}{*}{ M.IT } & $1.11 \ldots$ & ז.т... & $r$. & قبلي & \multirow[t]{2}{*}{ مشناركة } \\
\hline & & & &. .71 & 0.70 & r. & بعدي & \\
\hline \multirow[t]{2}{*}{ كبير } & \multirow[t]{2}{*}{$1 . r \varepsilon$} & \multirow{2}{*}{$\because v \varepsilon$} & \multirow[t]{2}{*}{$9 . .1$} & $1 . \wedge \leqslant \varepsilon \wedge \varepsilon$ & $1.9 \ldots$ & $r$. & قبلى & \multirow[t]{2}{*}{ نظام } \\
\hline & & & & .09 & $0.174 \mathrm{~V}$ & $r$. & بعدبي & \\
\hline \multirow[t]{2}{*}{ كبير } & \multirow[t]{2}{*}{ I.Y } & \multirow{2}{*}{.$v 1$} & \multirow[t]{2}{*}{ A.\&) } & $1 . \Delta r v \cdot \varepsilon$ & אשrא.1. & $r$. & قبلى & \multirow[t]{2}{*}{ مساعدة } \\
\hline & & & & $\therefore$ vo & 纟.ATrK & $r$. & بعدب & \\
\hline \multirow[t]{2}{*}{ كبير } & \multirow[t]{2}{*}{$1 . r 0$} & \multirow{2}{*}{.$\wedge$. } & \multirow[t]{2}{*}{$1 . . \times 9$} & 0.74791 & $1.00 \ldots$ & $r$. & قبلى & \multirow{2}{*}{ الانتماء } \\
\hline & & & & $1 . r \leqslant|r|$ & TY.ITTV & $r$. & بعدي & \\
\hline
\end{tabular}

$$
\text { يتضح من جدول (11) ما ليلي: }
$$

فاعلية البرنامج المقترح في تتمية مفاهيم الانتماء لاى أطفال الروضة (عينة الدراســة) ،

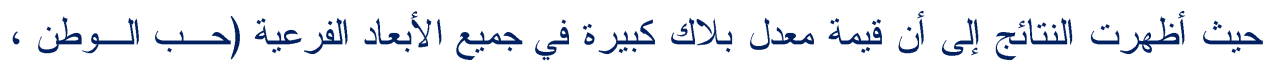

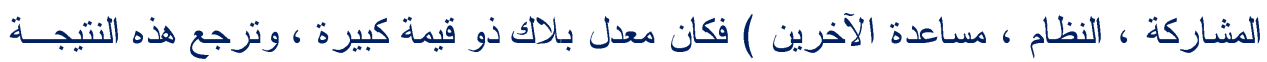

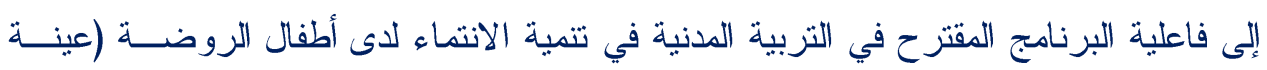

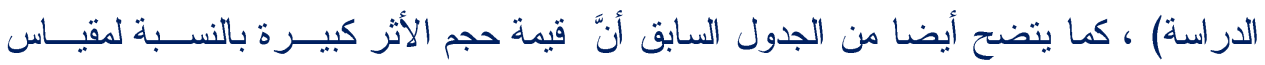

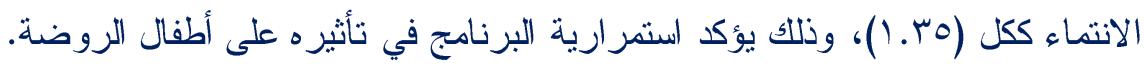


أ.د/ ماجدة هاشـم بخيت

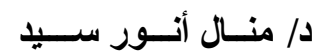

أثر التربية المدنية فى تتمية الاتتماء والمواطنة

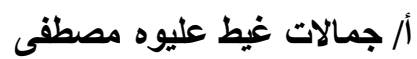

\section{تعقيب على نتائج الفرض الأول :}

اعتمد البرنامج على التنوع في الاستراتيجيات و الأنشطة المختلفة وإثارة حواس الطفل ؛لأن الطفل في هذه المرحلة يعتمد على حواسه بدرجة كبيرة في التعلم، ولهذا فإنَّ الأنشطة المختلفة هدفت إلى ربط الطفل بالأحداث الجارية والممارسات العملية، ومحاكاة المواقف ولعب الأدوار و إتاحة فرصة للأطفال في المشاركة في إعداد وتنفيذ تلك الأنشطة . وكذلك راعت تلك الأنشطة الفروق الفردية بين الأطفال والخصائص النمائية لهم ،كما راعت الأنشطة المقدمة أنّ الأطفال ( عينة الدراسة ) في أولى خطواتهم نحو الاحتكاك المباشر بالآخرين ؛ لأنّ علاقاتهم في هذه المرحلة ، تكاد تكون مقصورة على أسرهم فقط . أمسّا داخل الروضة فيزيد محيط احتكاكهم بالآخرين في نفس المرحلة العمرية تقريبًا . وبذلك فهم في حاجة إلى طرق فعّالة تهدف إلى إحداث تغيير واضح في سلوكياتهم و أفعالهم ، وتشكيل مفاهيم إيجابية عن طريق الممارسة العملية لهم • ثانيا : بالنسبة للفرض الثانى للتحقق من صحة الفرض الثانى الذي ينص " توجد فروق ذات دالة إحصائية بين متوسطي درجات المجموعة التجريبية والمجموعة الضابطة في تتميه المواطنة بعد تطبيق البرنامج لصالح المجموعة التجريبية ". تمت المقارنة بين نتائج مجموعة الدراسة في التطبيق القبلي والتطبيق البعدي لمقياس المواطنة المعدّ لهذا الغرض ، وتمّ حساب قيمة (ت) للفرق بين متوسطي درجات الأطفال في بئي التطبيق القبلي، و البعدي لمقياس المواطنة . 


\section{المجلة العلمية لكلية رياض الاطفال - جامعة اسيوط}

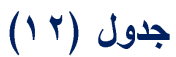

المتوسط الحسابى والإحراف المعيارى وقيمة (ت)

فى التطبيق القبلى والبعدى فى مقياس المواطنة

\begin{tabular}{|c|c|c|c|c|c|c|}
\hline الالالة & قيمة T & الانـدر اف المعياري & المثوسط & العدد & المجموعة & الأبعاد \\
\hline \multirow[t]{2}{*}{ دالة عند .... } & \multirow[t]{2}{*}{ A.VT } & $1 . V \leqslant 104$ & Y.TTV & r. & ضابطة & \multirow[t]{2}{*}{ قانون } \\
\hline & &. .71 & $0.77 \mathrm{~V}$ & r. & تجريبية & \\
\hline \multirow[t]{2}{*}{ دالة عند +... } & \multirow[t]{2}{*}{$11 . . r$} & 1.50700 & Y.VTV & r. & ضابطة & \multirow[t]{2}{*}{ قو اعد } \\
\hline & &.$v 1$ & 0.9 & r. & تجريبية & \\
\hline \multirow[t]{2}{*}{ دالة عند +... } & \multirow[t]{2}{*}{$1 . . r v$} & $1.0 \wedge \wedge \vee 0$ & Y. $\varepsilon$ & r. & ضابطة & \multirow[t]{2}{*}{ أر اء } \\
\hline & &.$V Y$ & $0 . V T$ & r. & تجريبية & \\
\hline \multirow[t]{2}{*}{ دالة عند ا +... } & \multirow[t]{2}{*}{$1 \cdot \ldots \leqslant 0$} & س.7. & איגומי & r. & ضابطة & \multirow[t]{2}{*}{ رأي } \\
\hline & & .94 & $0 . Y$ & r. & تجريبية & \\
\hline \multirow[t]{2}{*}{ دالة عند +... } & \multirow[t]{2}{*}{ Tr. } & $\varepsilon .01 \mathrm{~T} \cdot \mathrm{V}$ & $1 . .7 \mathrm{~V}$ & r. & ضابطة & \multirow{2}{*}{ مقيــاس المو اطنة } \\
\hline & & $1.0 V \varepsilon r r$ & rTY & r. & تجريبية & \\
\hline
\end{tabular}

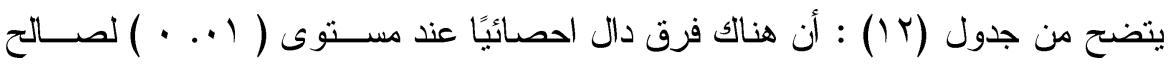

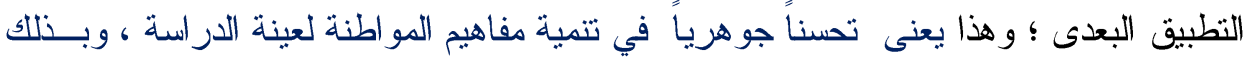

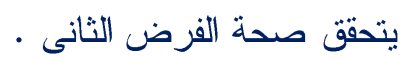

\section{تفسير النتائج المتعطقة بالقرض الثانى :}

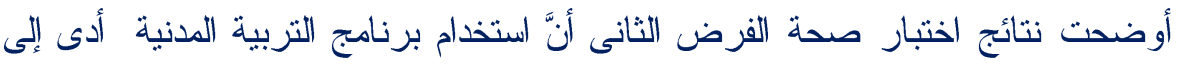

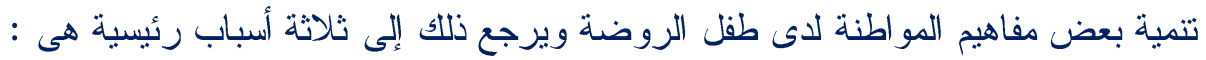

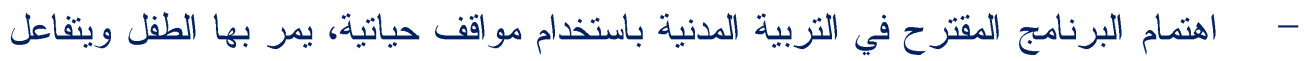

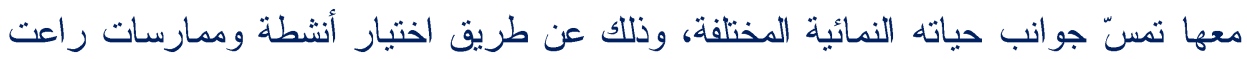
معايير مختلفة أهمها أنها تتتاسب والهاتهة المرحلة العمرية، ويسهل على الطفل تطبيقها، وإن احتاج

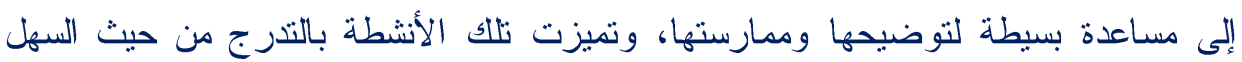

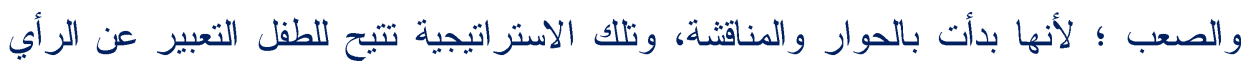

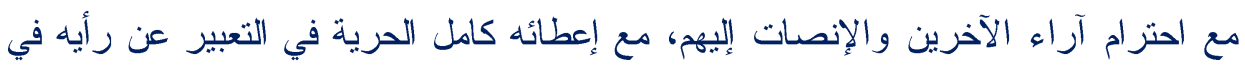

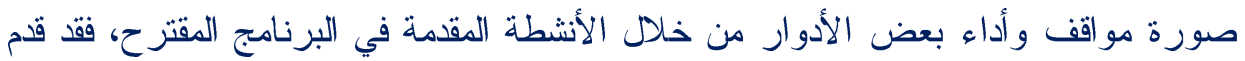


أ.د/ ماجدة هاشـم بخيت

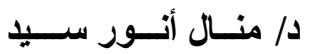

أثز التربية المدنية فى تتمية الاتتماء و المواطنة

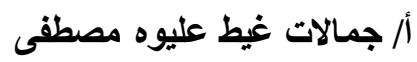

البرنامج مجموعة من المسرحيات والقصص المختلفة، والتي اهتثت بتتمية المواطنة لدى : لهى

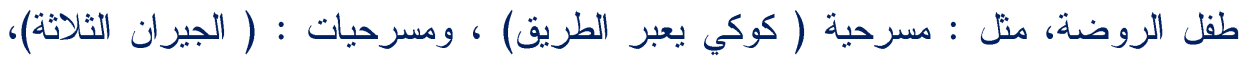

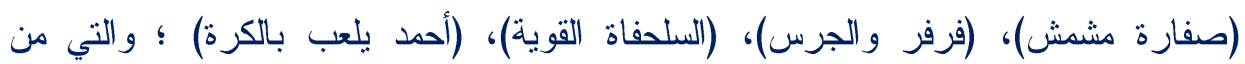

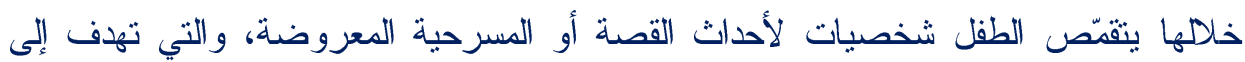
علاج بعض السلوكيات مثل : (الانطواء ، كما أنها تساعد على زيادة النقة بالنفس، العدوان ، و الاستحو اذ، السلبية ) •

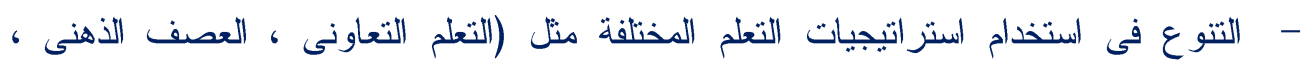

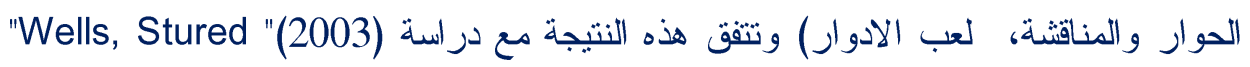

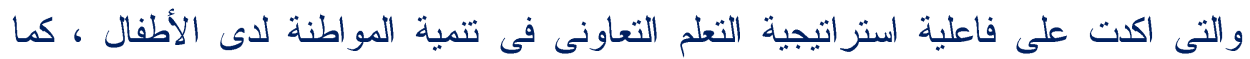

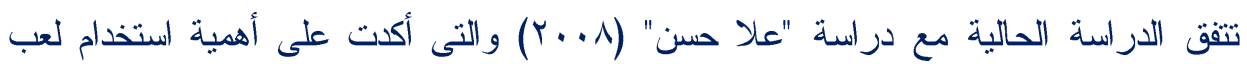
الأدوار فى تتمية المو اطنة لدى الأطفال .

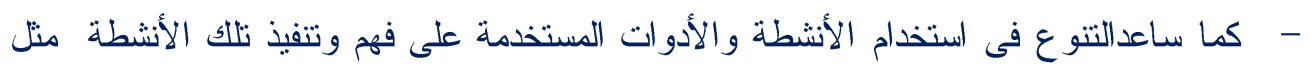

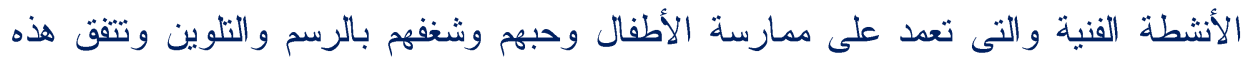

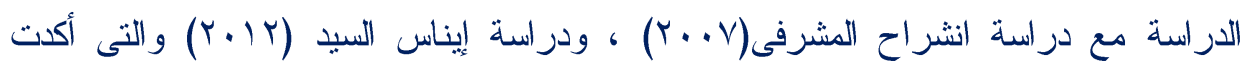
على أهية التنوع فى استخدام الأنشطة المختلفة فى تتمية المواطنة كما ساعد استخدام الأنشطة الحركية وتنفيذ هذه الأنشطة مع الأطفال إلى تلى تلتمية الثنعور

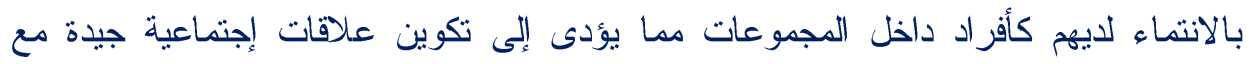

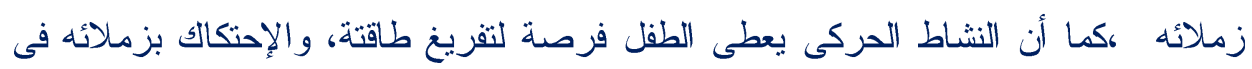
جو غير تقليدى يتسم بالحرية وتتفق هذه النتيجة مع الدراسات السابقة التالية:

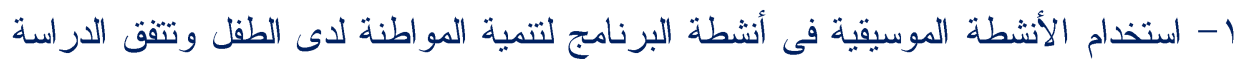

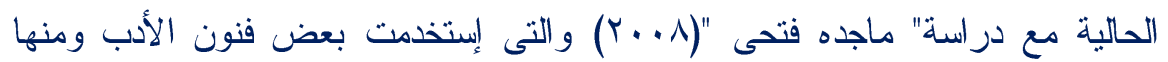
أنشطة الأغانى والأنانشيد الموسيقية . ץ- كما ساعد التنوع فى استخدام الأركان التعليمية إلى كسر حاجز الجمود والملل فى نفوس التئس

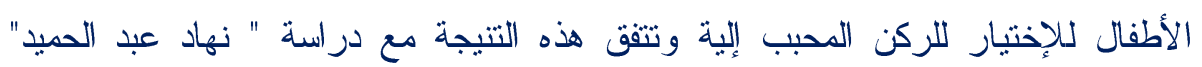

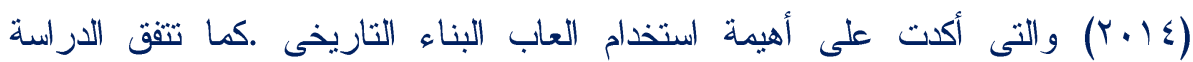

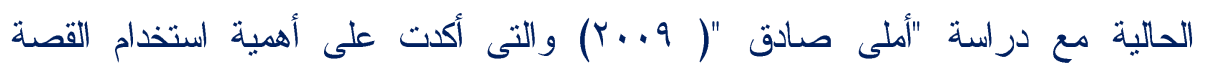

\section{r.lv الجلد الاول - العدد الثانى - يوليو}




\section{المجلة العلمية لكلية رياض الاطفال -جامعة اسيوط}

التاريخية ودورها فى تتمية المواطنة فى نفوس الأطفال ، كذلك ساعد استخدام مسرح

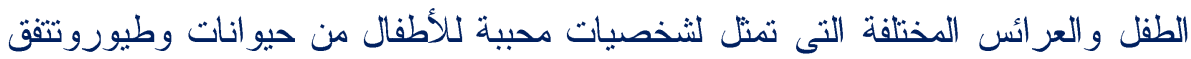

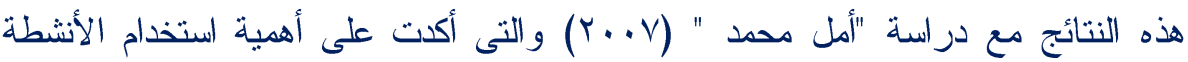

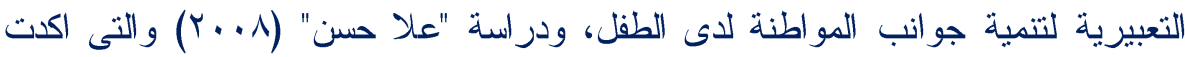
على أهمية استخدام النشاط المسرحى التثثيلى فى تتمية المواطنة لدى الطفل كما تتقق

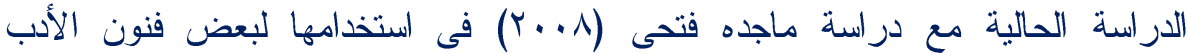

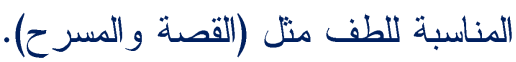
r- بالإضافة إلى استخدام الوسائل السمعية وكذلك استخدام الأنشطة المختلفة والتي تعتد بشكل مبانشر على ممارسة الطفل لدوره بحرية دون تقييد، مع التعبير عن رغباته من

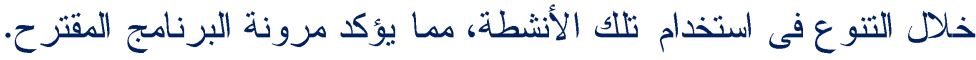
؟ - كما ساعد عنصر التقويم بعد كل نشاط على إكساب وفهم معنى المواطنة وكيفية تحقيقه بطرق مباشرة وغبر مبانشرة، من خلال الممارسة العطلية، والتي تعتبر أساساً تقوم عليه

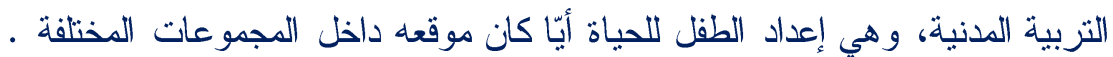
حجم الأثر ونسبة الكسب المعدل لبلاك:

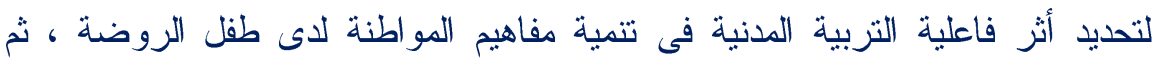
حساب نسبة الكسب المعدل لبلاك "Blake" ، حيث نتراوح نسبة الكسب المعدلة بين

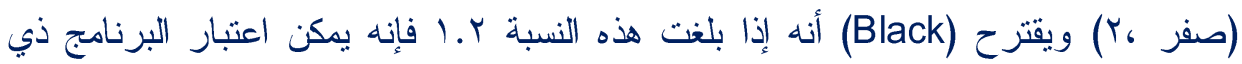


أ.د/ ماجدة هاشـم بخيت

د/ منــال أنــور ســـــ

أثز التربية المدنية فى تتمية الاتتماء و المواطنة

أ/ جمالات غيط عليوه مصطقى

جلول (ri (i)

المتوسط الحسابى والإحر اف المعيارى وقيمة (ت)

وحجم الآثر ومعدل بلاك لمقياس المواطنة

\begin{tabular}{|c|c|c|c|c|c|c|c|c|}
\hline الدلاكة & معلد & ريتا & قيمة T & الالمحر افيار ي & المتوسط & العدد & التطبيق & الأبعاد \\
\hline \multirow[t]{2}{*}{ كبيز } & \multirow[t]{2}{*}{$1 . \leqslant}$. & \multirow{2}{*}{.$V Y$} & \multirow[t]{2}{*}{$\Lambda . V T$} & $1 . V \leqslant \wedge 04$ & Y.Y૫V & r. & قبلى & \multirow{2}{*}{ قانون } \\
\hline & & & &. .71 & $0.74 \mathrm{~V}$ & r. & بعدي & \\
\hline \multirow[t]{2}{*}{ كبير } & \multirow[t]{2}{*}{1.01} & \multirow{2}{*}{$\cdot .11$} & \multirow[t]{2}{*}{$11 . . r$} & $1 . r 0700$ & Y.VTV & $r$. & قبلي & \multirow[t]{2}{*}{ قو اعد } \\
\hline & & & &.$v 1$ & 0.9 & r. & بعدي & \\
\hline \multirow[t]{2}{*}{ كبيز } & \multirow[t]{2}{*}{$1 . \leqslant 9$} & \multirow{2}{*}{$\because v q$} & \multirow[t]{2}{*}{$1 . . r V$} & $1.011 \mathrm{Vo}$ & Y. $\varepsilon$ & r. & قبلي & \multirow[t]{2}{*}{ أراء } \\
\hline & & & &.$V Y$ & 0.17 & r. & بعدي & \\
\hline \multirow[t]{2}{*}{ كبيز } & \multirow[t]{2}{*}{$1 . r V$} & \multirow{2}{*}{.$v 9$} & \multirow[t]{2}{*}{$1 . . \leq 0$} & אד. & אזה 1. & r. & قبلي & \multirow[t]{2}{*}{ رأي } \\
\hline & & & & 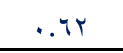 & $0 . r$ & $r$ r. & بعدي & \\
\hline \multirow[t]{2}{*}{ كبيز } & \multirow[t]{2}{*}{1.4} & \multirow{2}{*}{.$\wedge 4$} & \multirow[t]{2}{*}{ Ir. } & $\varepsilon .01 \mathrm{r} \cdot \mathrm{V}$ & $1 . .7 \mathrm{~V}$ & r. & قبلي & \multirow{2}{*}{ مقياس } \\
\hline & & & & $1.0 V \leqslant r r$ & TH.rt & $r$. & بعدي & \\
\hline
\end{tabular}

يتضح من جدول (با) قيمة حجم الأثر كبيرة لمقياس مفاهيم المواطنة، وذللك يؤكد

استمرارية البرنامج في تأثيرة على الأطفال ومعدل بلاك أكبر هن النسبة التي حددها بلاكك (Y. ())، حيث بلغ معدل الكسب لبلاك للمقياس ككلهس.1 وهي نسبة كبيرة، تؤكد أثز البرنامج البرنامج المقترح في نتمية المواطنة لدى أطفال الروضة (عينة الدراسة)، حيث أظهرت النتائج إلى أن قيمة دعدل بلاك كبيرة في جميع الأبعاد الفرعية (قانون، قواعد ، آراء ، رأى)، وترجع هذه النتيجة إلى أثر الثربية المدنية في تنمية مفاهيم المواطنة لدى أطفال الروضة (عينة الدر اسة)، وذلك يؤكد استمر ارية البرنامج في تأثيره على أطفال الروضة. 


\section{المجلة العلمية لكلية رياض الاطفال -جامعة اسيوط}

\section{تعقيب على نتائج الفرض الثانى :}

1- وترجع تلك النتيجة إلى مناسبة برنامج التزبية المدنية لخصائص أطفال العينة واستخدامه

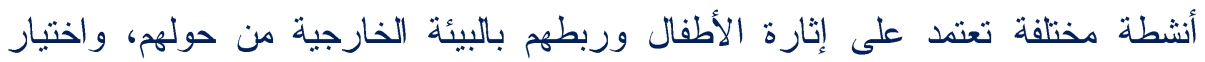

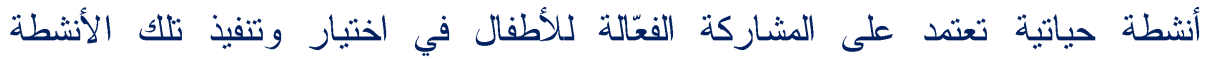

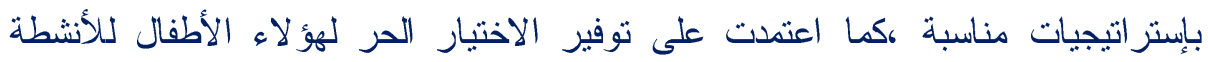

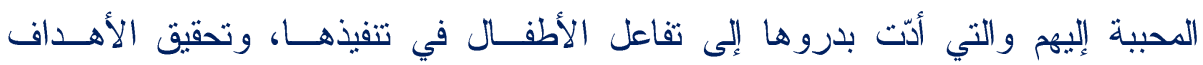

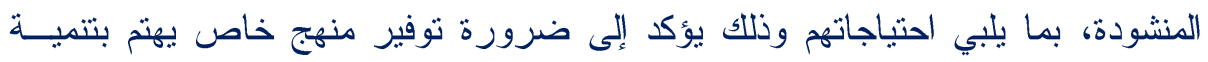
المواطنة للى الطفل وتتفق نتائج هذه الدراسة مع دراسة " Barry Abdoulaye

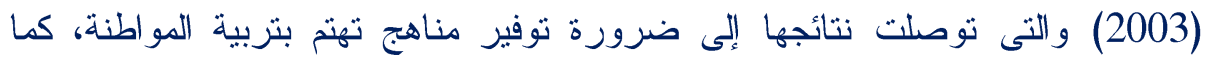

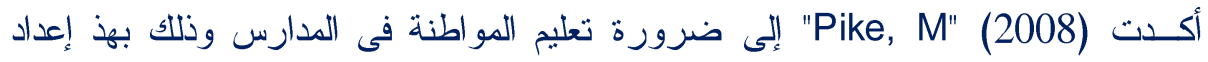
الطفل للحياة الديمقر اطية . الطان

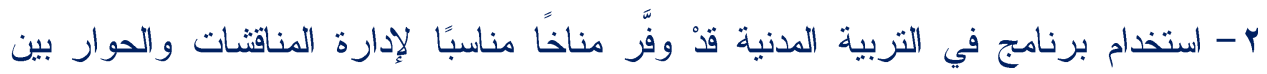
الأطفال و المعلمة وبين الأطفال وبعضهم البعض فئل ، وحيث إن عينة الدراسة تشمل أطفال

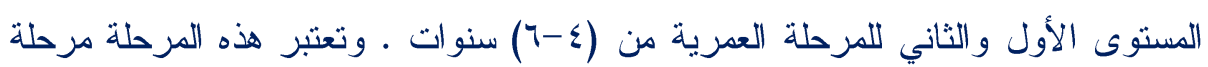

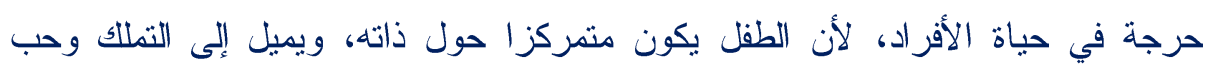

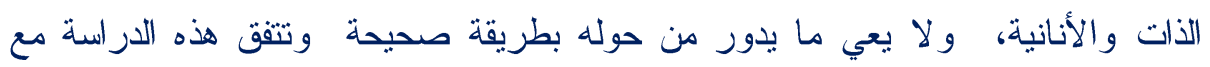

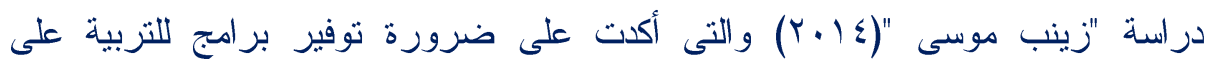

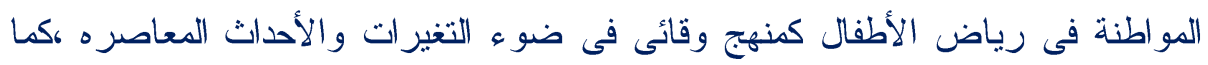

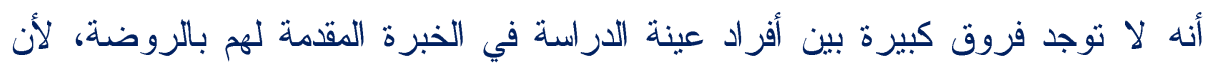

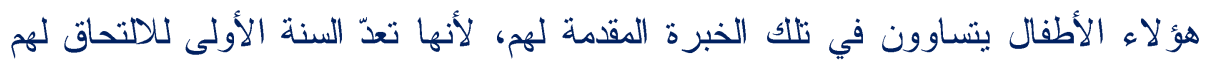

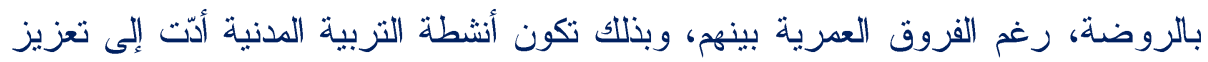

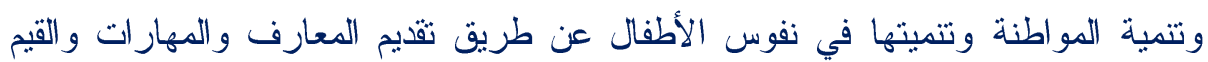

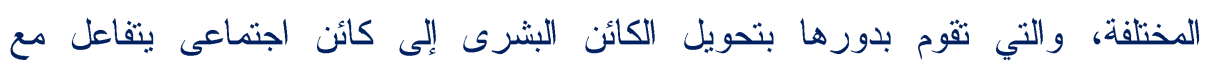
المحيطين به من حوله في ضوء قو انين وقو اعد محدة من قبل المجتمع المحيط به.

\section{تثاثثا : بالنسبة للفرض الثالث}

للتحقق من صحة الفرض الثالث الذى ينص على: " توجد فروق ذات دالة إحصائية بين متوسطات درجات المجموعة التجريبية والمجموعة الضابطة في تنمية المسئولية الاجتماعية بعد تطبيق البرنامج لصالح المجموعة التجريبية". 
أ.د/ ماجدة هاشـم بخيت

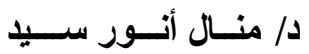

أثز التربية المدنية فى تتمية الانتماء و المواطنة

أ/ جمالات غيط عليوه مصطقى

تمت المقارنة بين نتائج مجموعة الدراسة في التطبيق القبلي و التطبيق البعدي لمقياس

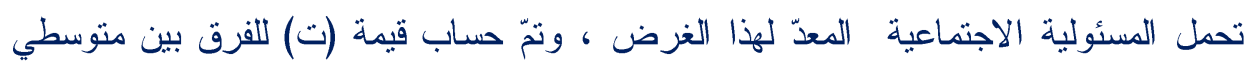

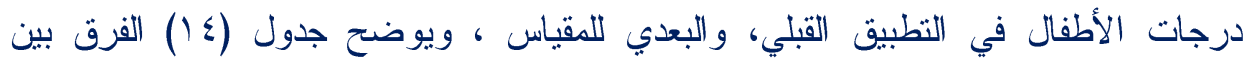

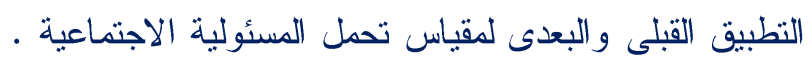

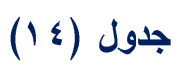

المتوسط الحسابى والإحر اف المعيارى وقيمة (ت) فى التطبيق القبلى والبعدى لمقياس تحمل المسئولية الاجتماعية

\begin{tabular}{|c|c|c|c|c|c|c|}
\hline الالالة & قيمة T & الالنحر اف المعياري & المتوسط & العدد & المجموعة & الأبعاد \\
\hline \multirow{2}{*}{ دالة عند } & \multirow{2}{*}{ M.Y人 } & $Y . A Y \leq 0 Y$ & A.Err & $r$. & ضابطة & \multirow{2}{*}{ المشاركة } \\
\hline & & $r . V .99 r$ & אسז7. & r. & تجريبية & \\
\hline \multirow{2}{*}{ دالة عند } & \multirow[t]{2}{*}{$1 Y . .7$} & Y.OEOY & V.. 7TV & r. & ضابطة & \multirow[t]{2}{*}{ بعد السلوك } \\
\hline & & $1.97 \varepsilon \cdot \varepsilon$ & IE.YYTV & r. & تجريبية & \\
\hline \multirow{2}{*}{ دالة عند } & \multirow[t]{2}{*}{$|Y . \leqslant|$} & r.1774ะ & V.A... & r. & ضابطة & \multirow[t]{2}{*}{ ملابس } \\
\hline & & Y.SVYOY & $18 . .77 V$ & r. & تجريبية & \\
\hline \multirow{2}{*}{ دالة عند } & \multirow[t]{2}{*}{17.1.} & $Y . \wedge \varepsilon .09$ & $9 . \ldots$ & r. & ضابطة & \multirow[t]{2}{*}{ نظام } \\
\hline & & $r . r) \leq 7 r$ & rسזع. • r & r. & تجريبية & \\
\hline \multirow{2}{*}{ دالة عند } & \multirow[t]{2}{*}{$18 . .7$} & $1.9 \leq . \leq 9$ & $7.7 \ldots$ & r. & ضابطة & \multirow[t]{2}{*}{ طعام } \\
\hline & & 1.7900. & IE.VYTV & r. & تجريبية & \\
\hline \multirow{2}{*}{ دالة عند } & \multirow[t]{2}{*}{ IV.ry } & r.VVOQY & אسזו. • & r. & ضابطة & \multirow[t]{2}{*}{ أمن } \\
\hline & & Y.ANYOV & זrז...r & r. & تجريبية & \\
\hline \multirow{2}{*}{ دالة عند } & \multirow[t]{2}{*}{1 1 . $\leqslant q$} & $r . V \leqslant \varepsilon \wedge \Lambda$ & $9.9 \ldots$ & r. & ضابطة & \multirow[t]{2}{*}{ نظافة } \\
\hline & & $1.7 r \leq \varepsilon$. & מسזו. • r & r. & تجريبية & \\
\hline \multirow{2}{*}{ دالة عند } & \multirow[t]{2}{*}{ r } & $\Lambda . \vee \leqslant \Lambda) \leqslant$ & س & $r$. & ضابطة & \multirow{2}{*}{ الاعثداد } \\
\hline & & T.. YYAT & חאז & $r$. & تجريبية & \\
\hline \multirow{2}{*}{ دالة عند } & \multirow[t]{2}{*}{ ro.Vr } & 11.V.r.r & سr.9.9 & r. & ضابطة & \multirow{2}{*}{ المسئولية } \\
\hline & & $V .0$. & אז.0. & r. & تجريبية & \\
\hline
\end{tabular}

$r+r \vee r \wedge r$ 


\section{المجلة العلمية لكلية رياض الاطفال -جامعة اسيوط}

يتبين من جدول (\{ () أن هناك فروق ذات دالة احصائية عند مســتوى دلالـــة (1 .. • )

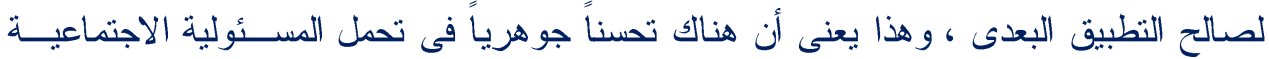
لعينة الدراسة وبذلك يتحقق صحة الفرض الثران الثالث

\section{تفسير النتائج المتعلقة بالفرض الثالث :}

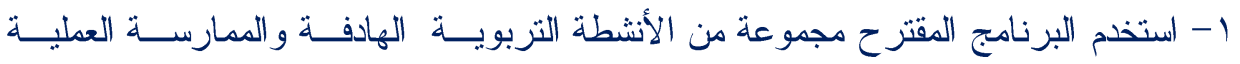

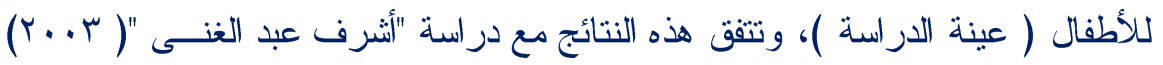

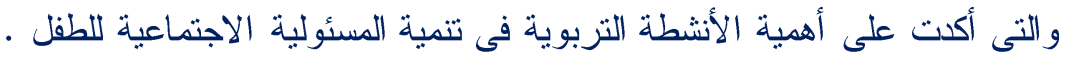

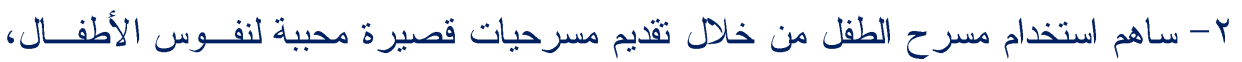

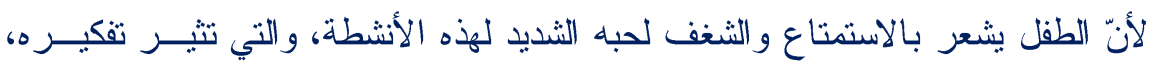

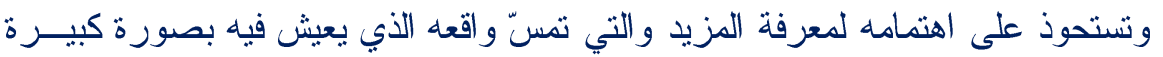

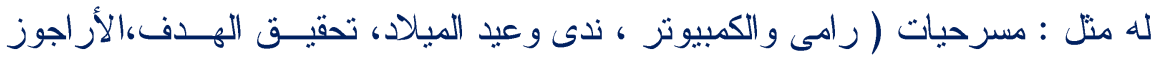

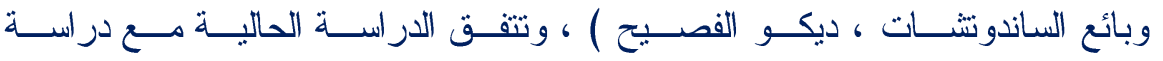

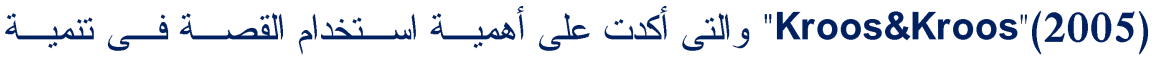

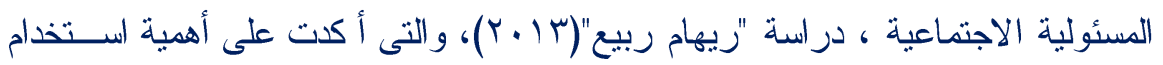

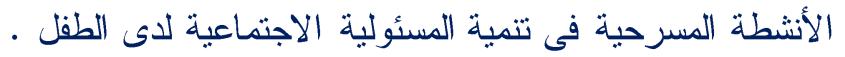

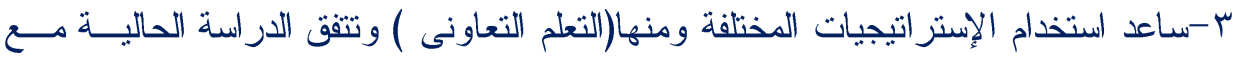

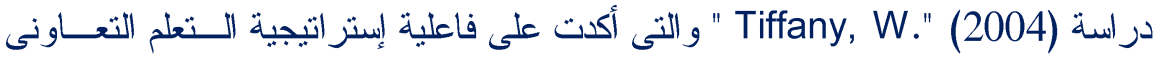

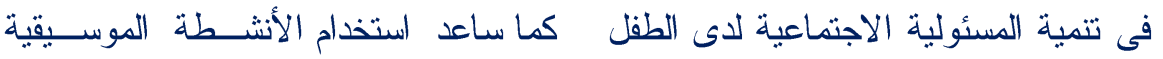

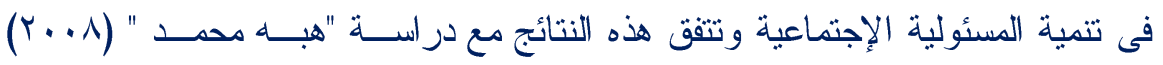

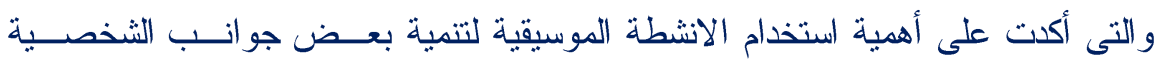

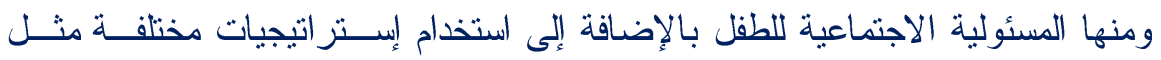

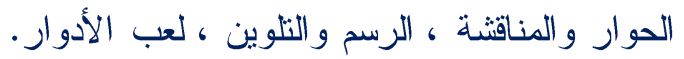

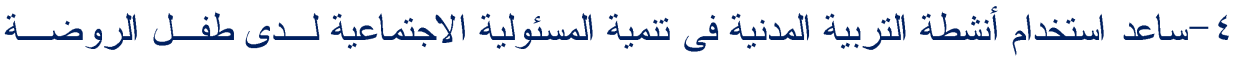

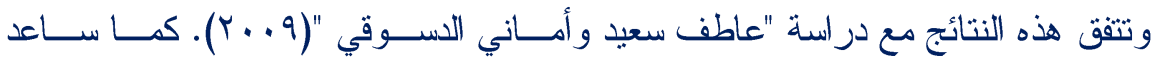

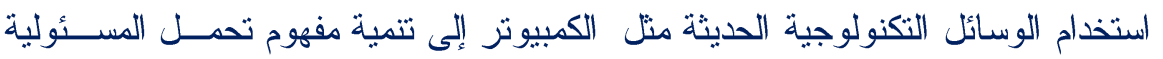

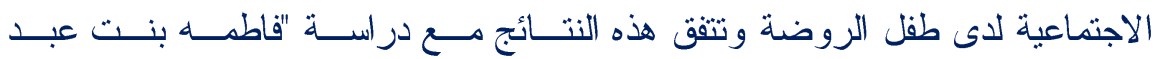

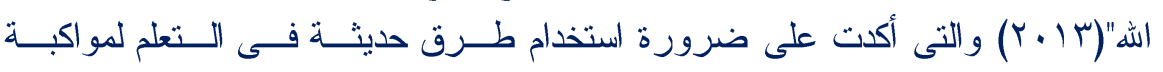

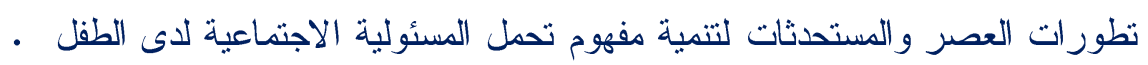


أ.د/ ماجدة هاشـم بخيت

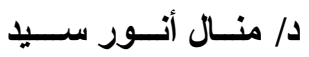

أثر التربية المدنية فى تتمية الاتتماء والمواطنة

أ/ جمالات غيط عليوه مصطقى

الكسب المعدل وحجم الأثر : - الكب

جدول (10)

المتوسط الحسابي والاحمراف المعياري وقيمة (ت) وحجم الأثر

ومعدل بلاك لمقياس تحمل المسئولية الاجتماعية والائية

\begin{tabular}{|c|c|c|c|c|c|c|c|c|}
\hline الالاكة & معلال & مربع & قيمة T & الالحمر اف & المستوسط الحسب & العدد & التطبيق & الأبعاد \\
\hline \multirow[t]{2}{*}{ كبير } & \multirow{2}{*}{1.5} & \multirow{2}{*}{..$\wedge 1$} & \multirow[t]{2}{*}{$11 . \mathrm{KA}$} & Y.AY $\leq 0 Y$ & 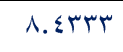 & $r$ r. & قبلي & \multirow[t]{2}{*}{ المشاركة } \\
\hline & & & & $r . V \cdot 99 Y$ & אسז7. 17. & r. & بعدي & \\
\hline \multirow[t]{2}{*}{ كبير } & \multirow{2}{*}{1.59} & \multirow{2}{*}{. } & \multirow[t]{2}{*}{ IY..T } & r.OE OY & V.. צדV & r. & قبلي & \multirow[t]{2}{*}{ السلوك } \\
\hline & & & & $1.97 \leq . \leq$ & Iร.YบหV & $r$. & بعدي & \\
\hline \multirow[t]{2}{*}{ كبير } & \multirow{2}{*}{$1 . r 0$} & \multirow{2}{*}{.90} & \multirow[t]{2}{*}{ rE.Tr } & $\Lambda . V \leq \lambda) \leq$ & س & $r$. & قبلي & \multirow[t]{2}{*}{ الاعتمـاد } \\
\hline & & & & 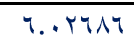 & 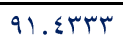 & $r$. & بعدي & \\
\hline \multirow[t]{2}{*}{ كبير } & \multirow{2}{*}{$1 . \leqslant 1$} & \multirow{2}{*}{.997} & \multirow[t]{2}{*}{ YO.VY } & r.V.r. & אזr.9 & r. & قبلي & \multirow{2}{*}{ المسئولية } \\
\hline & & & & V.o. & سז.0. & r. & بعدي & \\
\hline
\end{tabular}

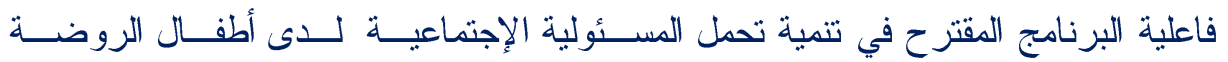

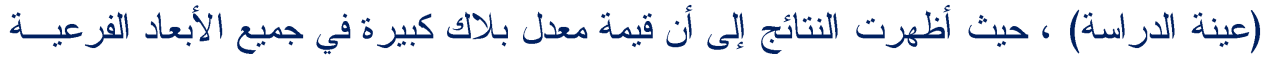

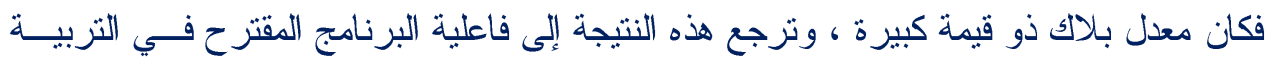

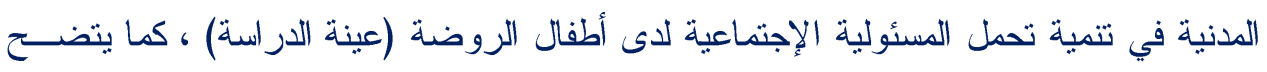

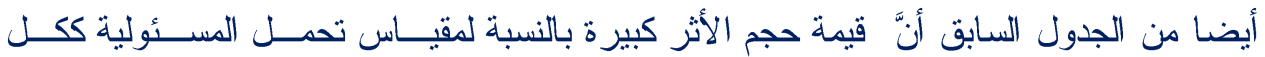

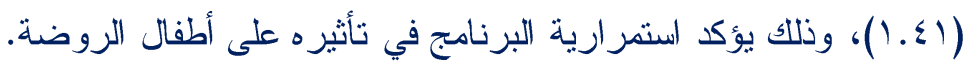




\section{المجلة العلمية لكلية رياض الاطفال -جامعة اسيوط}

\section{تعقيب على نتائج الفرض الثالث :}

أوضحت نتائج اختبار صحة الفرض الثالث أنّ استخدام برنامج الثربية الددنية و تفعيل

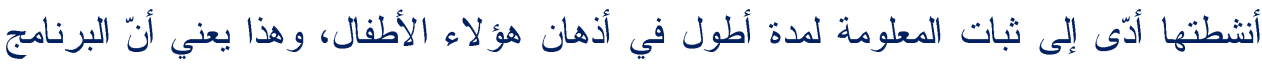

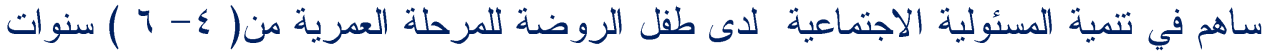
، واستمر هذا الأثر بعد تطبيق البرنامج لدة شهر من تطبيقه ـ ويرجع ذلك إلى ما تتاوله

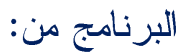

1-الأشطة والتتريبات التي تم تُوْظِفها في البرنامج :حيث كانت من الأنشطة المحببة التي

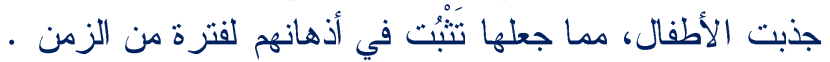

r-التعزيز المادي والمعنوي : والذي كان يُقََّ عند نجاح الطفل في أداء المهمة المطلوبة

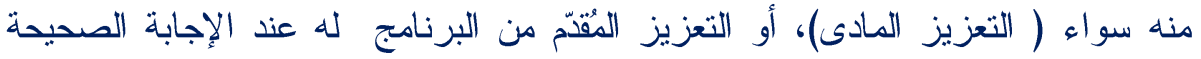

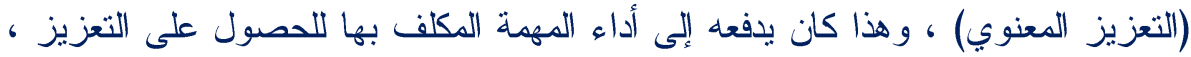

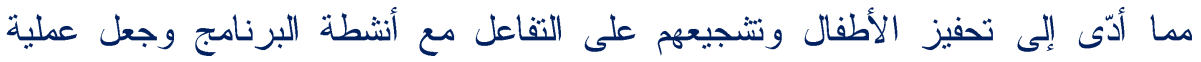

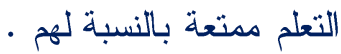

ب-التّريب المستمر : وذللك على كل نثاط من أنثطة البرنامج إضافة إلى التكرار في

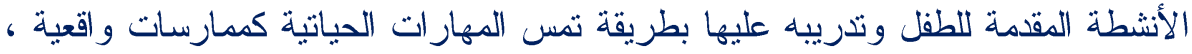

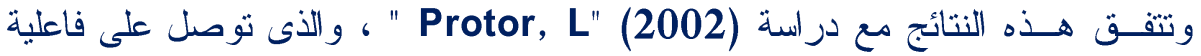
برنامج فى التكيف الإجتماعى عـن طريق تقديم نماذج إيجابية لتنمية المسئولية الاجتماعية، دراسة (2002) "Kim" و التى توصلت إلى فاعلية البرنامج الإرشادى المقام

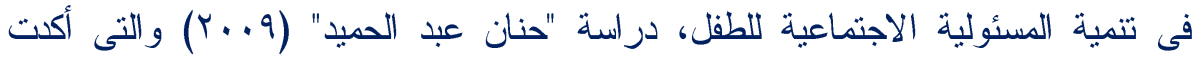
فاعلية البرنامج المستخدم لتنمية المسئولية الاجتماعية لطفل الروضة الرية.

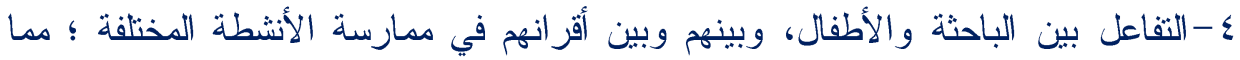
أناح للأطفال التعلم عن طريق النموذج ، وتعدّ هذه الطريقة من أكثر الطرق فئر فاعلية للتعلم

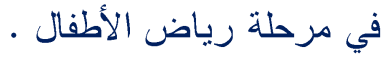

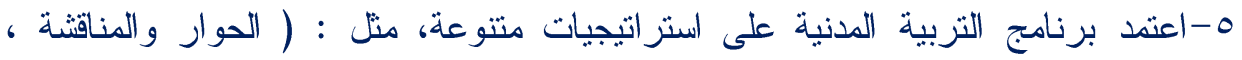

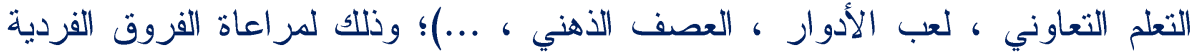

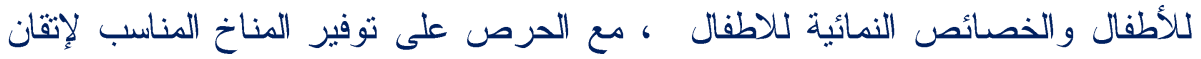

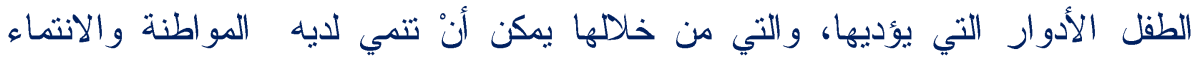

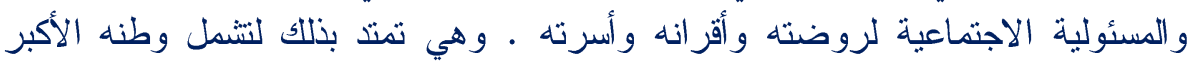

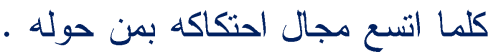


أ.د/ ماجدة هاشـم بخيت

د/ منــال أنــور ســـــ

أثر التربية المدنية فى تتمية الاتتماء والمواطنة

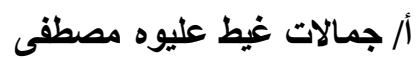

تعقيب عام على نتائج الاراسة :

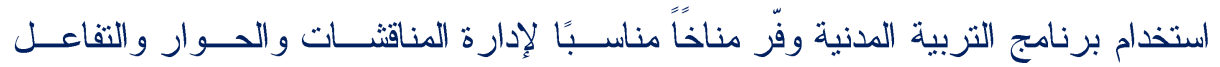

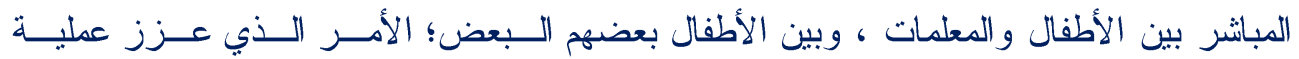

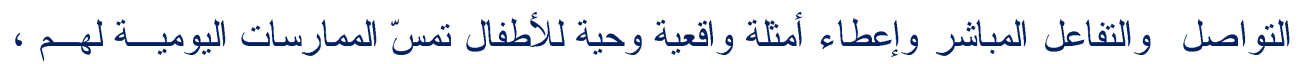

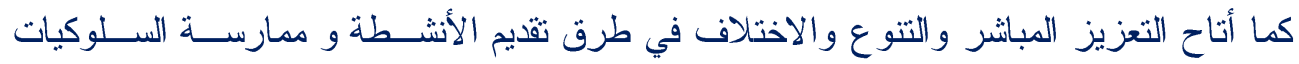

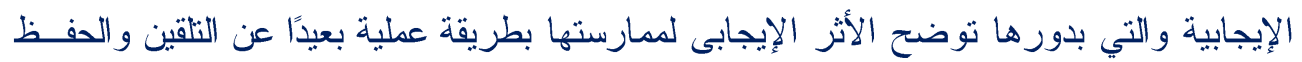

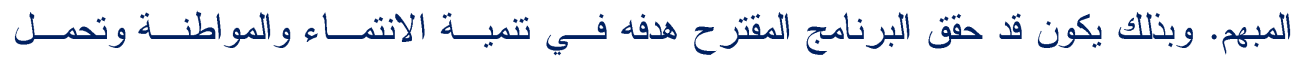

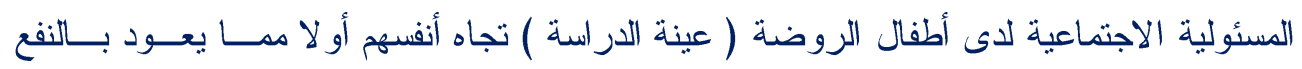

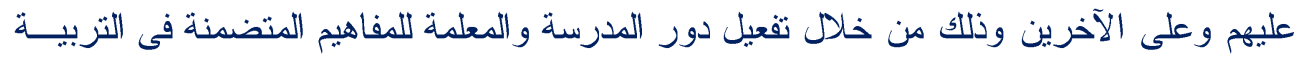

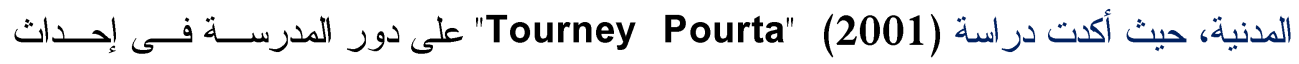

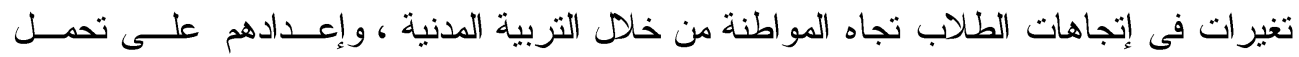
المسئولية و المشاركة بإيجابية فى المجتمع وكذلك دور المعلم من خلال المعارف و المفــاهيم التـى لـى

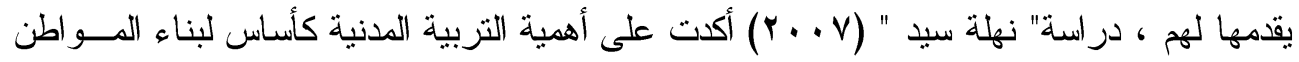

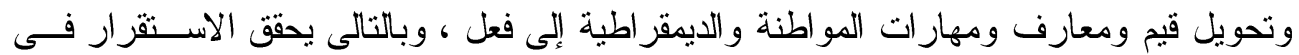

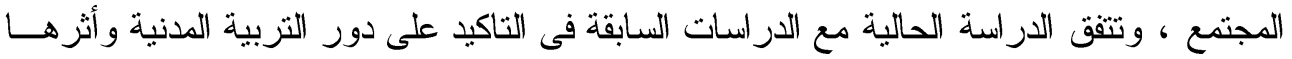

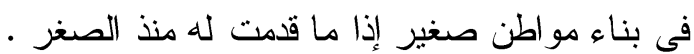

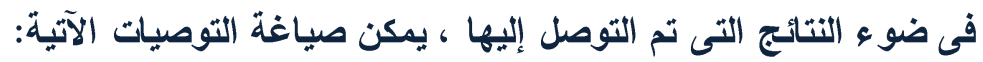

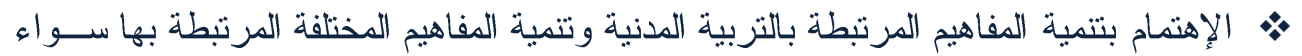

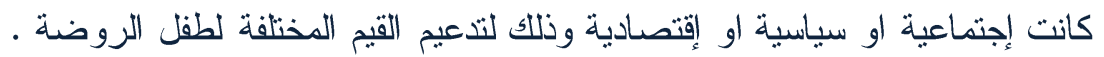

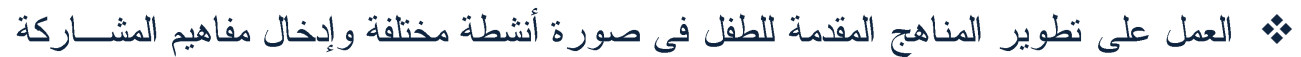
،وذللك من أجل تتمية قيم التزبية الددنية لدى الأطفال .

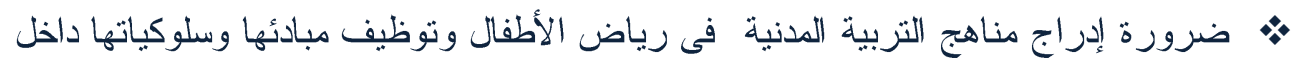

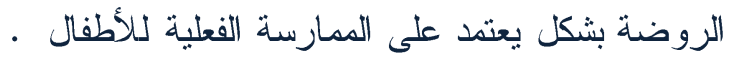

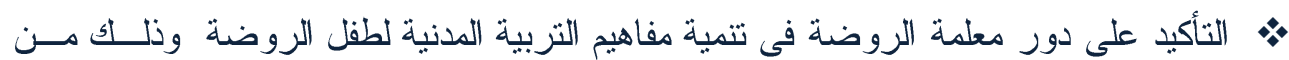
خلال برامج وتدريبات مكثقة لها للتعرف على أن التربية الددنية إتجاه حديث فى لتى التربية . 


\section{المجلة العلمية لكلية رياض الاطفال -جامعة اسيوط}

ضرورة توعية الأسرة من خلال لقاءات توعية و أدلة مطبو عة لتتمية ســلوكيات النزبيــة

المدنية و المفاهيم المرتبطة بها لديهم مثل الإنتماء و المواطنة و الدسئولية الإجتماعية .

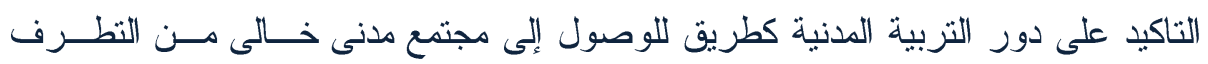
و العنف، كغاية للوصول إلى التقام و الرقى.

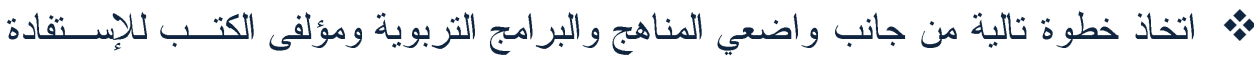

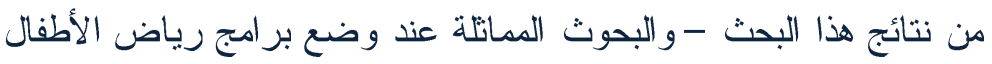
بحوث ودر اسات مقترحة:

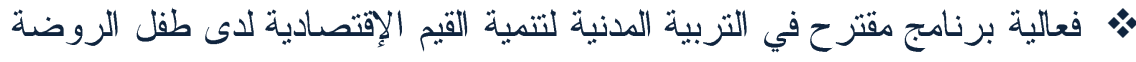

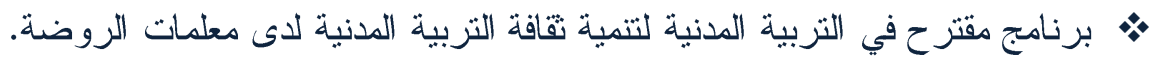

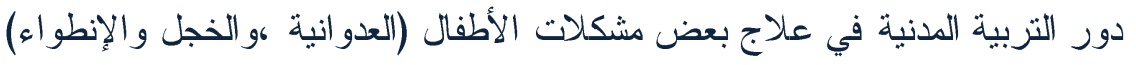

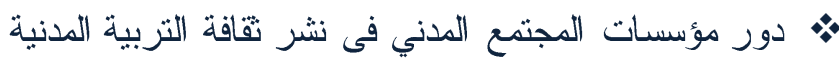

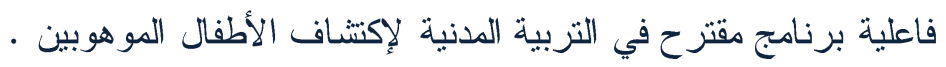

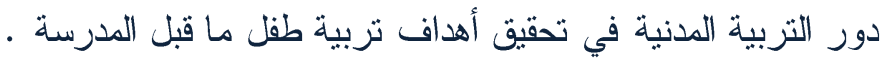

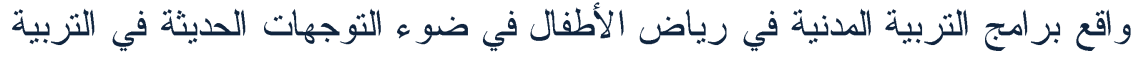

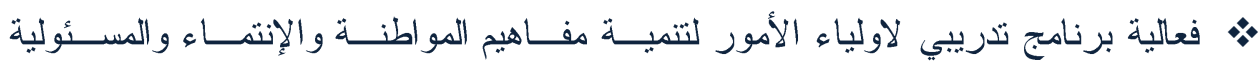

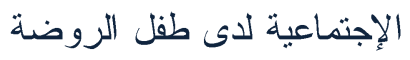


أ.د/ ماجدة هاشـم بخيت

د/ منــال أنــور ســـــ

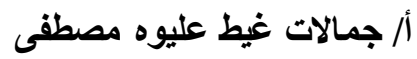

\section{أولاًا : المراجع العربية}

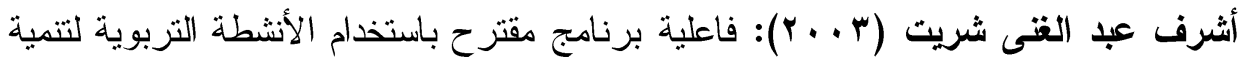

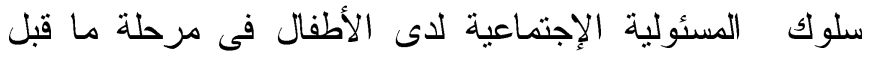
المدرسة،مجلة دراسات عربية فى علم النفس، كلية الأداب،

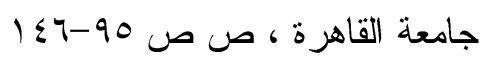

أمل السيد خلف (؟ . r): التشئئة السياسية لطفل ما قبل المدرسة ،القاهرة ، عالم الكتب . أمل محمد أحمد (V) . . . P): برنامج مقترح قائم على الأنشطه التعبيرية لتتمية جوانب المو اطنة

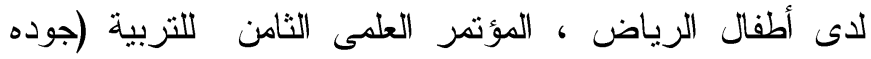

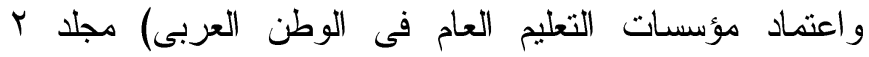

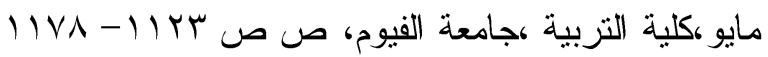

أملى صادق ميخائيل (q ج . r): فاعلية القصص التاريخية فى إكساب طفل الروضة المعرفة

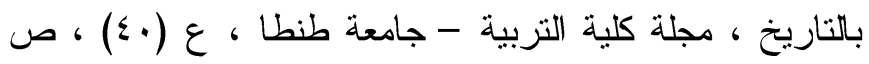

$$
\text { ص ص }
$$

أنشراح أبراهيم المشرفى (V V. . r): فاعلية برنامج التربية على المواطنة وحقوق الإنسان

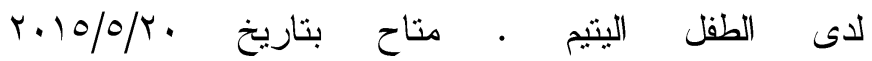

Http://www.almarefah.co/article.php

إيمان محمود السيد ( ( + Y): أثز برنامج أنشطة حركية في تتمية بعض عناصر الانتماء

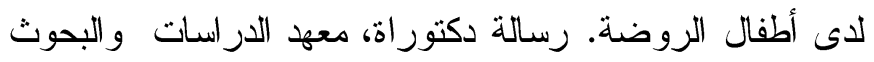

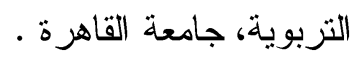

أيمن عبدة محمد (r r r) : تأثير برنامج تعليمى باستخدام الألعاب التربوية على

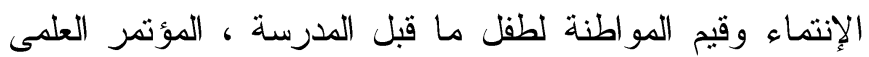

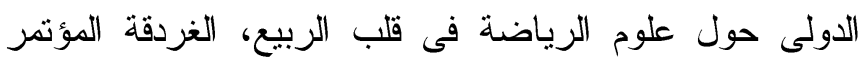

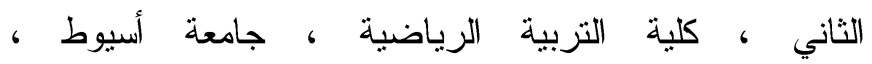

$$
\text { ص ص ص .11 }
$$

إيناس إبراهيم أحمد ( • ب r ) ): الاتجاهات المعاصرة في التربية للمواطنة ، دراسة تحليليه

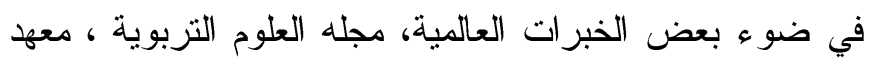

$$
r \text { r.lv rAN }
$$




\section{المجلة العلمية لكلية رياض الاطفال -جامعة اسيوط}

الدراسات و البحوث التربوية ، جامعة القاهرة ، مجلد( 1) (1)،

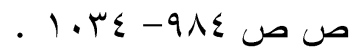

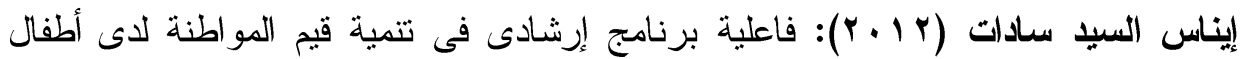

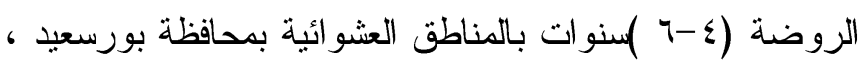

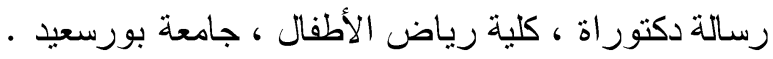

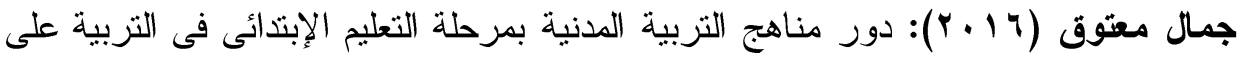

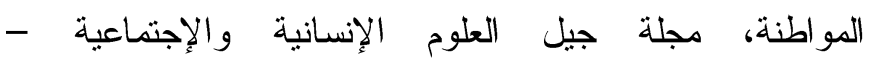

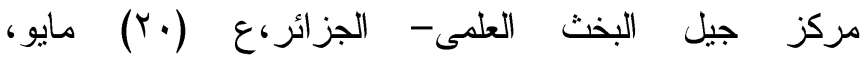

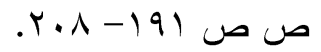

حسنية عنيمى عبد المقصود(11) + (1): التنمية البشرية لمعلمات الروضة وأثرها على مفهوم المواطنة لدى أطفال ما قبل المدرسة، مجلة الطفولة العربية

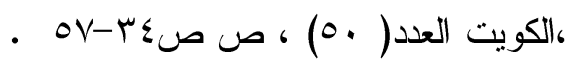

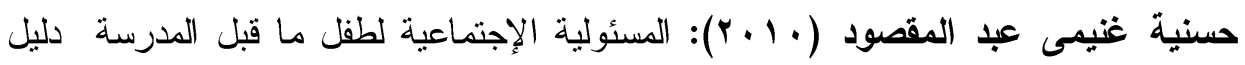

$$
\text { عملي، دار الفكر العربي، القاهرة . }
$$

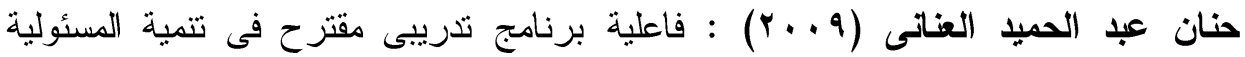

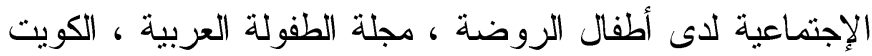

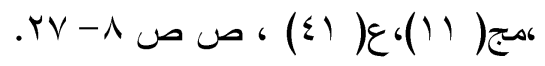

رانيا عيسى الرشدان (9 . ؟): فاعلية برنامج تعليمى مقترح فى التربية الوطنية والمدنية

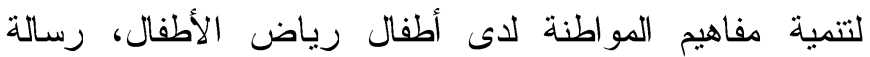

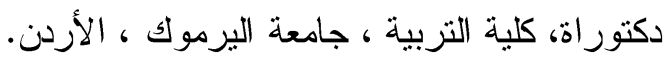

ريهام ربيع العيوطى( r 1 ب) : فعالية برنامج إرشادى باستخدام بعض الأنشطة المسرحية

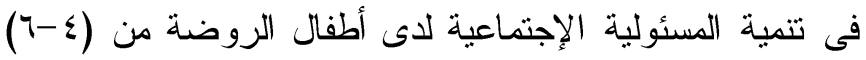

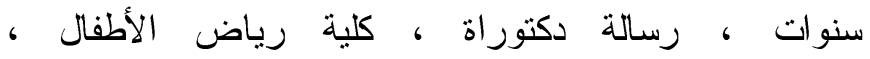

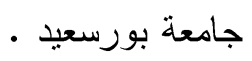

زمزم محمد عمر ( ب ا ب): فاعلية استخدام الدخل البصرى المكانى فى تدريس منهج رياض

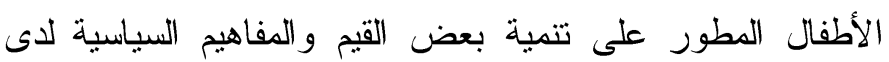

$$
\text { أطفال الروضة، رسالة ماجستير ، كلية التربية، جامعة سوهاج. }
$$


أ.د/ ماجدة هاشـم بخيت

د/ منــال أنـــور ســـــ

أثز التربية المدنية فى تتمية الاتتماء والمواطنة

أ/ جمالات غيط عليوه مصطفى

سماح خالد عبد القوى (r r ب): دراسة مقارنة لأثز بعض المتغيرات فى تشكيل هوية انتماء

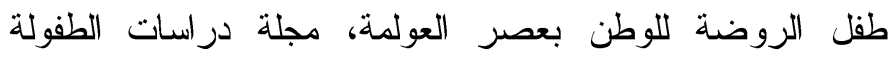

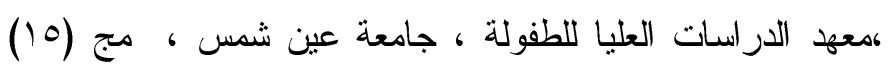

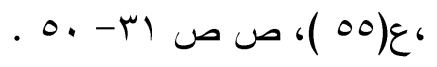

سمية حسام أبو بكر (r I + r): الانتماء الوطنى وعلاقتة بمستوى الطموح لدى الأطفال، مجلة

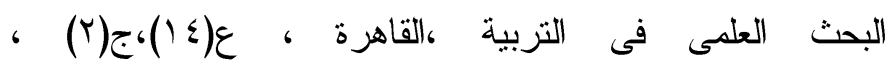

$$
\text { ص صن }
$$

شيرين عباس عراقى (r M r r): فاعلية برنامج قائم على الأنشطة المتكاملة لتعليم المفاهيم الإجتماعية لتنمية الوعى السياسى لدى أطفال مرحلة الرياض ،مجلة دراسات عربية في التربية وعلم النفس ، رابطة التربوبينه

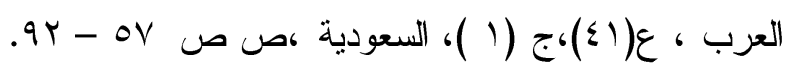

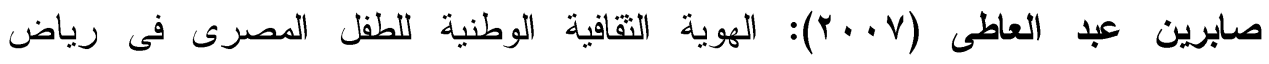

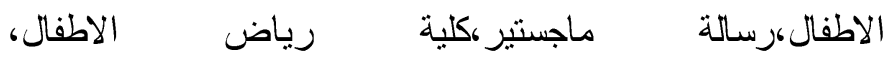

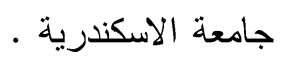

عاطف محمد سعيد ، امانى إبراهيم الاسوقى (9 + . ץ): فاعلية برنامج مقترح فى التربية

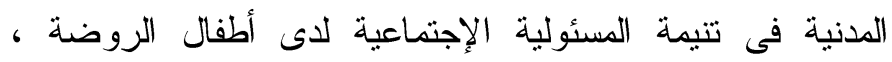

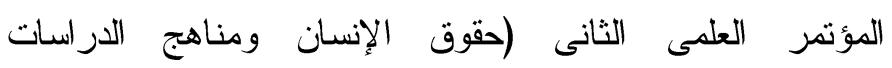

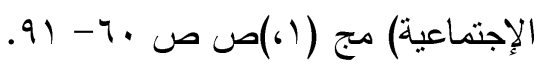

علا حسن كامل (^ . . r): فاعلية برنامج نشاط تمثيلى مسرحى فى تنمية المواطنة لاطفال الروضة، رسالة دكتوراه غير منشورة ، كلية الآداب ، جامعة

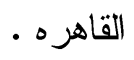

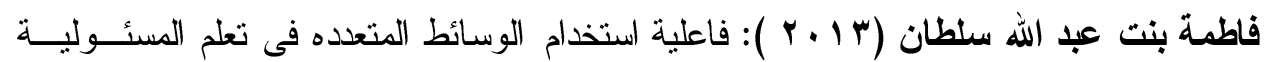
الإجتماعية لدى أطفال ما قبل المدرسة الإبتدائية فى مدينة

$$
\text { الطائف ، رسالة ماجستير ،كلية التربية ،جامعة أم القرى }
$$


لمياء أحمد محد الصغير (r ب ب): توظيف النماذج المتحفية في تتمية الإنتماء لدى أطفال

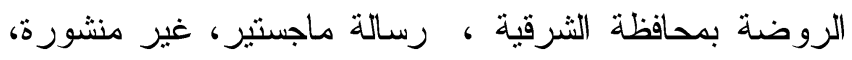

$$
\text { - كلية رياض أطفال ، جامعة القاهرة . }
$$

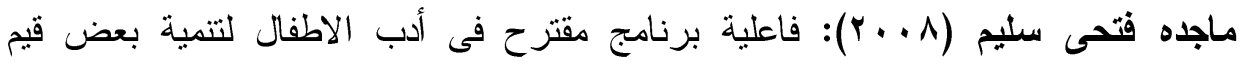

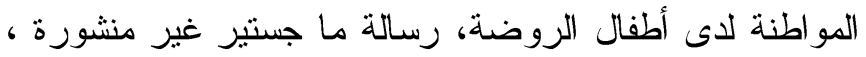

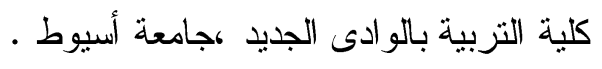

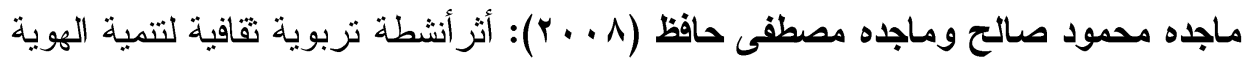

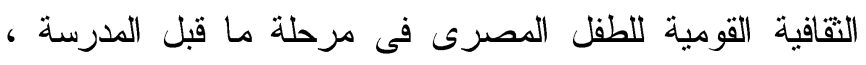

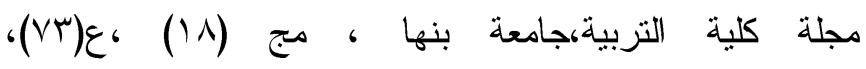

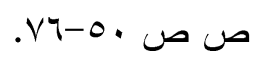

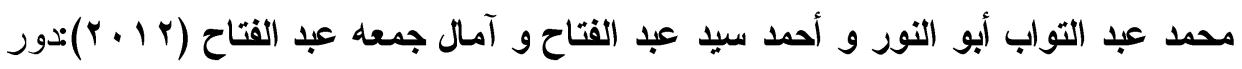

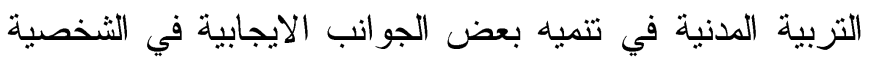

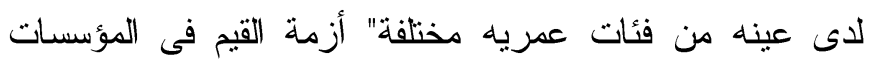

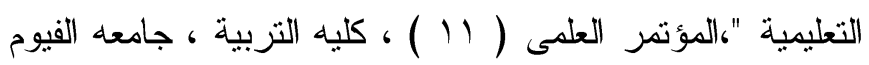

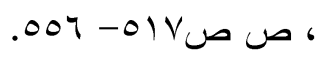

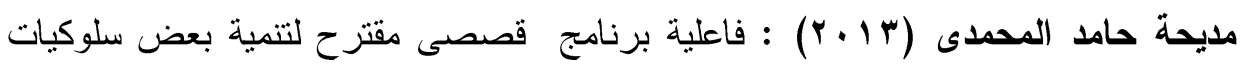

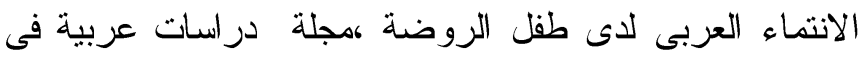

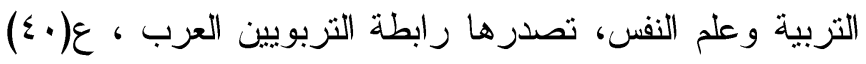

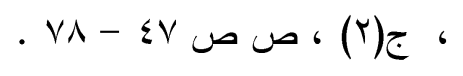

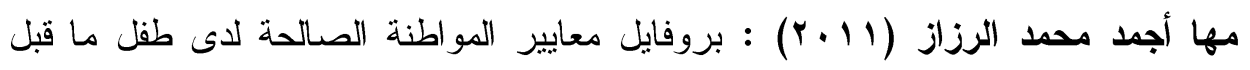

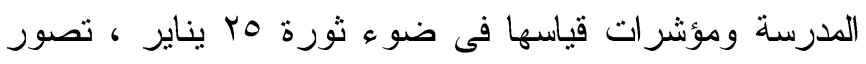

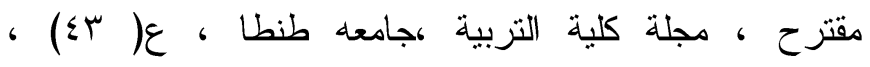

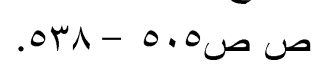

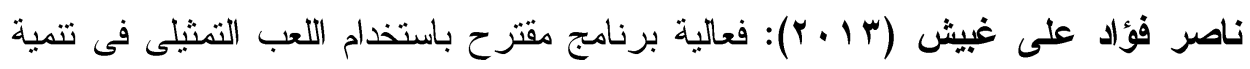

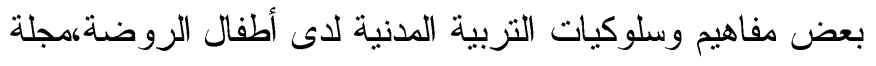

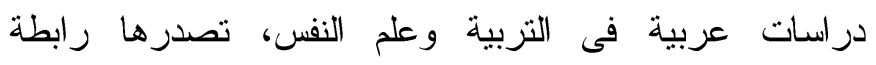

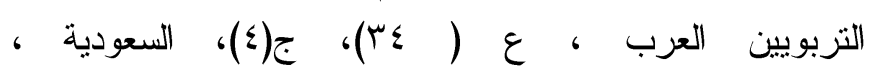

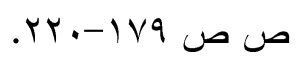


أ.د/ ماجدة هاشـم بخيت

د/ منــال أنــور ســـــ

أثز التربية المدنية فى تتمية الاتتماء والمواطنة

أ/ جمالات غيط عليوه مصطفى

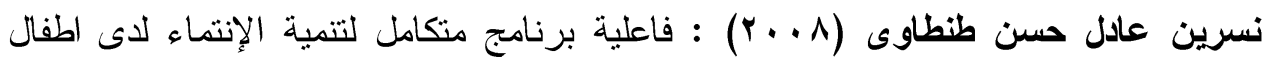

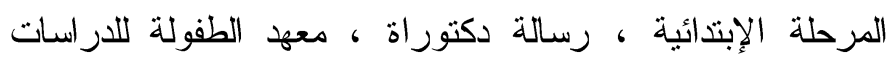

$$
\text { التربوية ، جامعة عين شمس • الابنه }
$$

نهاد عبد الحميد أحمد ( ( r r) : تتمية بعض قيم المواطنة لدى طفل الروضة باستخدام ألعاب

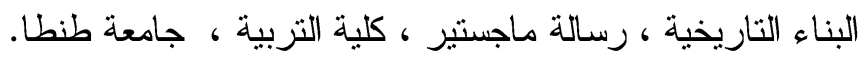

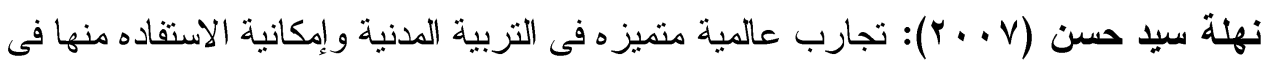

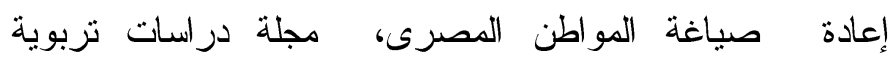

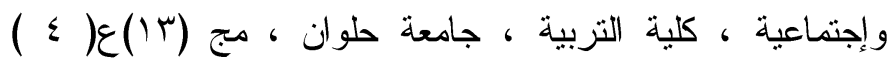

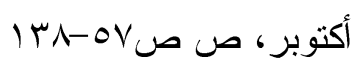

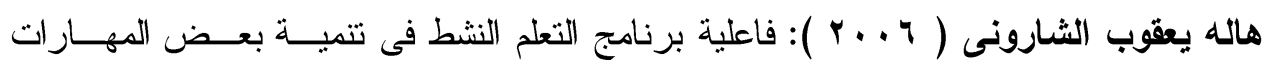

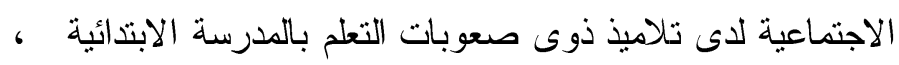

رسالة ماجستير ،مركز دراسات ثربوية ،جامعة القاهرة

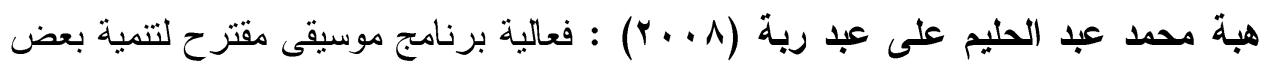
سمات الثخصية لدى طفل رياض الاطفال ، رسالة دكتور اة ، كلية

$$
\text { رياض الأطفال ،جامعة الاسكندرية }
$$

وفاء محمد سيا عثمان (Y (Y): فاعلية استخدام مسرح العرائس فى تتفيذ منهج (حقى إلعب أتعلم وأبتكر ) على تتمية بعض المفاهيم الإجتماعية

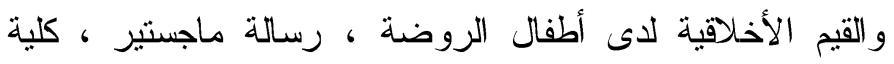

$$
\text { التربية ،جامعة سوهاج }
$$

ولاء أحمد محمد (ع ا؟Y): دور بعض الأنشطة المقترحة لمركزي المتحف والأسرة في

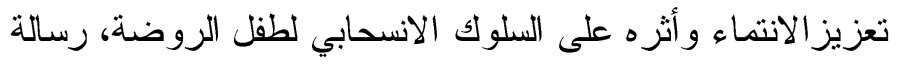

$$
\text { ماجستير، كلية التربية ، جامعة أسيوط. }
$$

يوسف عبد الله الصغير(ع ا • r): دور بعض المؤسسات التربوية فى غرس المسئولية الإجتماعية لاىى الطفل فى ضوء النموذج الإسلامى، دراسة تحليلية ، رسالة ماجستير ، كلية التزبية ، جامعة أسيوط. 


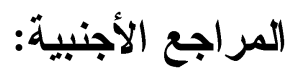

Barry Abdoulaye (2003):Citoyenneté, éducationà la Citoyenneté et programmesd'études .Commission du programmes de 'etudes Quebec, Available at: http www.edu.cit.htm. Access: 19/5/2016

Fisher, P. ,(2011): Performativity, well-being, social class and citizenship in English schools EDUCATIONAL STUDIES, 37 (1),49-58

Great School Staff, (2004): The state of Civic Education, Teaching the citizen of Tomorrow, Childrens Civic Knowledge is lagging, but some groups are taking.http:// www.greatschools. org / Student / academicskills162

Jane Thomas, (2010): " Re-constructing children's identities : social work knowledge and practice in the assessment of children's identities", Cardiff University.

Juil, E(2005): Role of Social dramatic with children education al values . Journal of personality and social psychology. (98)No (6), June ,pp203-219

Kim , S.,( 2008): Teacher -Child interactions in voluntary prekindergarten programs in child care settings: A critical analysis of barriers and facilitations. Ph.D. thesis, university of Florida

Kroos \& Kroos (2005) Social values for children. child Development. vol57 (1) pp102-119 

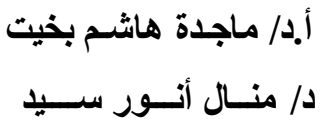

أثر التربية المدنية فى تتمية الاتتماء و المواطنة

Mellor, Kennedy\&Green Wood. (2003): Learning and working long Kindergarten, www.eiv.ced.org pdf $\$ scopev2.pdf.

Obrin, R., (2006): Moral and Social values in the children's books Journal of children's Literature. Vol. (43), No (3), March, pp 132-149.

- Pike, M. (2008): Faith in citizenship? On teaching children to believe in liberal democracy. British Journal of Religious Education, (30) 2, 113-122

Prentice, M., \& Robinson, G. (2007). Linking service learning and civic engagement in community college students. American Association of Community Colleges,pp14

Protor, L (2002): Violence exposure friendship and social adjustment among head start preschoolers , DAIA58(02)p278

Sahar Yacoub, Abu-Helu (2013). The Role of The Kindergarten Teacher in Enhancing The Child's perceptions: Medwell Journals The Social sciences 8(4):351-358

Starkey, (2011), Affiliation with the development of kindergarten children in both Britain and France, International, Journal, of Reality, therapy Fal, Vol.17D:37-41

Tiffany, W. (2004): An investigation of the use cooperative Learning teaching with sample of children (0-4) across traditional daycare and playgroup learning communities. Diss. Abs. Inter., 65(3A),833

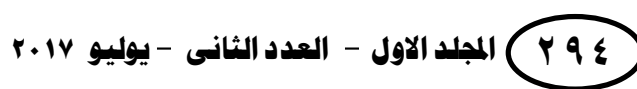




\section{المجلة العلمية لكلية رياض الاطفال - جامعة اسيوط}

Tourney, Porta \& Other (2001): Civic Knowledge and Enjoyment at Age 14 in 28 Country Result from LEA Civic Education Study -ERIC Digest.

Wells, Stured (2003), Middle School Education, The Critical Link in Dropout Prevention, Clearing House on Urban Education, New York.

Zeinab Mousa El-Samahy(2014):Citizenship Education as an Approach to Preventive Education in the Institutions of Kindergarten, Child Rearing Department, Faculty of Kindergarten, University of Port Said, Egypt,pp 232 . 